Prepared in cooperation with the

Rhode Island Water Resources Board

\title{
Long-Term Ground-Water Levels and Transmissivity in the Blackstone River Basin, Northern Rhode Island
}

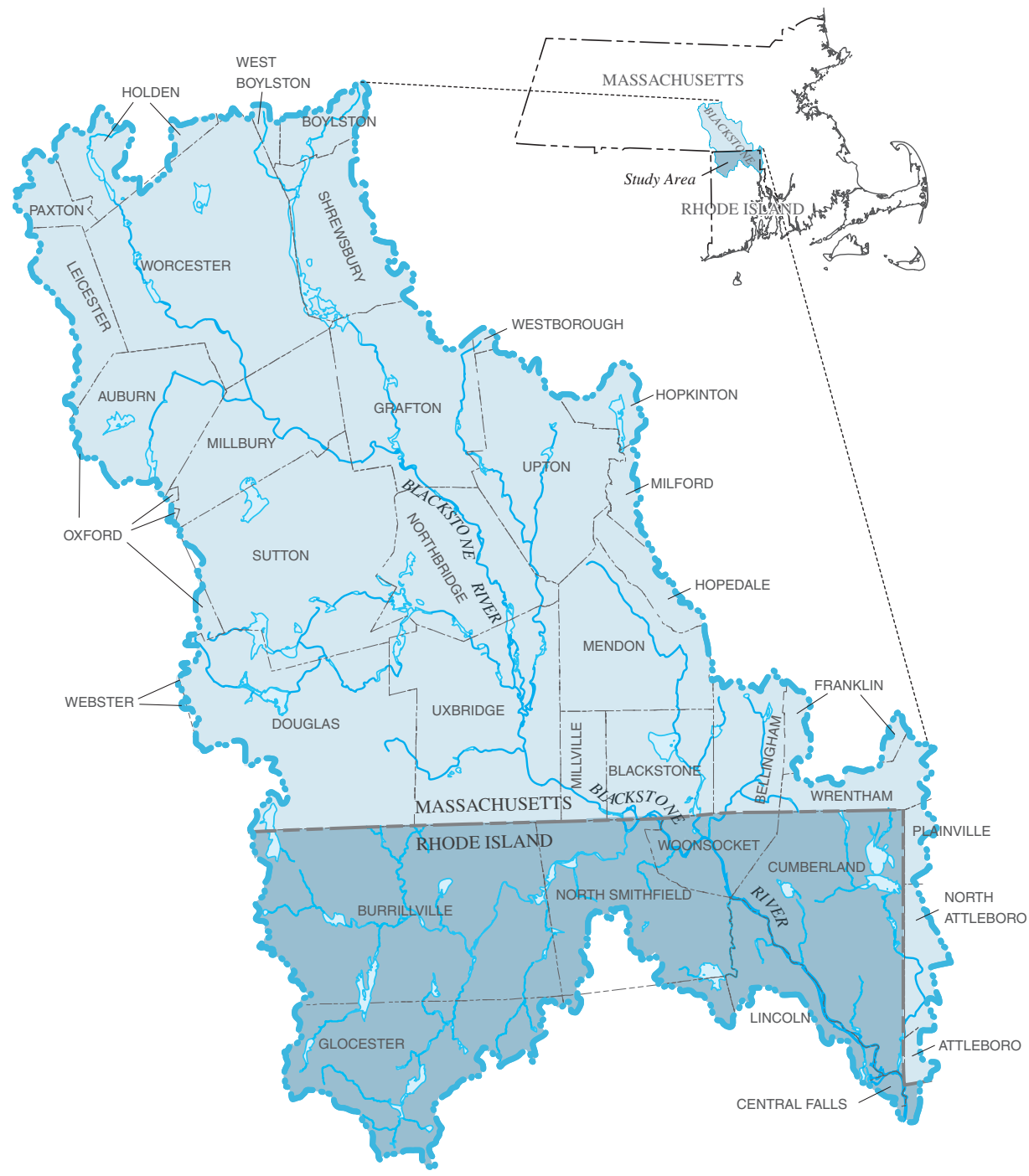

Scientific Investigations Report 2006-5295 
For additional information call or write to:

Director, U.S. Geological Survey

Massachusetts-Rhode Island Water Science Center

10 Bearfoot Road, Northborough, MA 01532

(508) 490-5000

http://ma.water.usgs.gov 


\section{Long-Term Ground-Water Levels and Transmissivity in the Blackstone River Basin, Northern Rhode Island}

By Jack R. Eggleston, Peter E. Church, and Jeffrey R. Barbaro

Prepared in cooperation with the

Rhode Island Water Resources Board

Scientific Investigations Report 2006-5295 


\section{U.S. Department of the Interior DIRK KEMPTHORNE, Secretary}

\section{U.S. Geological Survey \\ Mark D. Myers, Director}

\section{U.S. Geological Survey, Reston, Virginia: 2007}

For product and ordering information:

World Wide Web: http://www.usgs.gov/pubprod

Telephone: 1-888-ASK-USGS

For more information on the USGS--the Federal source for science about the Earth, its natural and living resources, natural hazards, and the environment:

World Wide Web: http://www.usgs.gov

Telephone: 1-888-ASK-USGS

Any use of trade, product, or firm names is for descriptive purposes only and does not imply endorsement by the U.S. Government.

Although this report is in the public domain, permission must be secured from the individual copyright owners to reproduce any copyrighted materials contained within this report.

Suggested citation:

Eggleston, J.R., Church, P.E., and Barbaro, J.R., 2007, Long-term ground-water levels and transmissivity in the Blackstone River Basin, northern Rhode Island: U.S. Geological Survey Scientific Investigations Report 2006-5295, 48 p., 2 pls. 


\section{Contents}

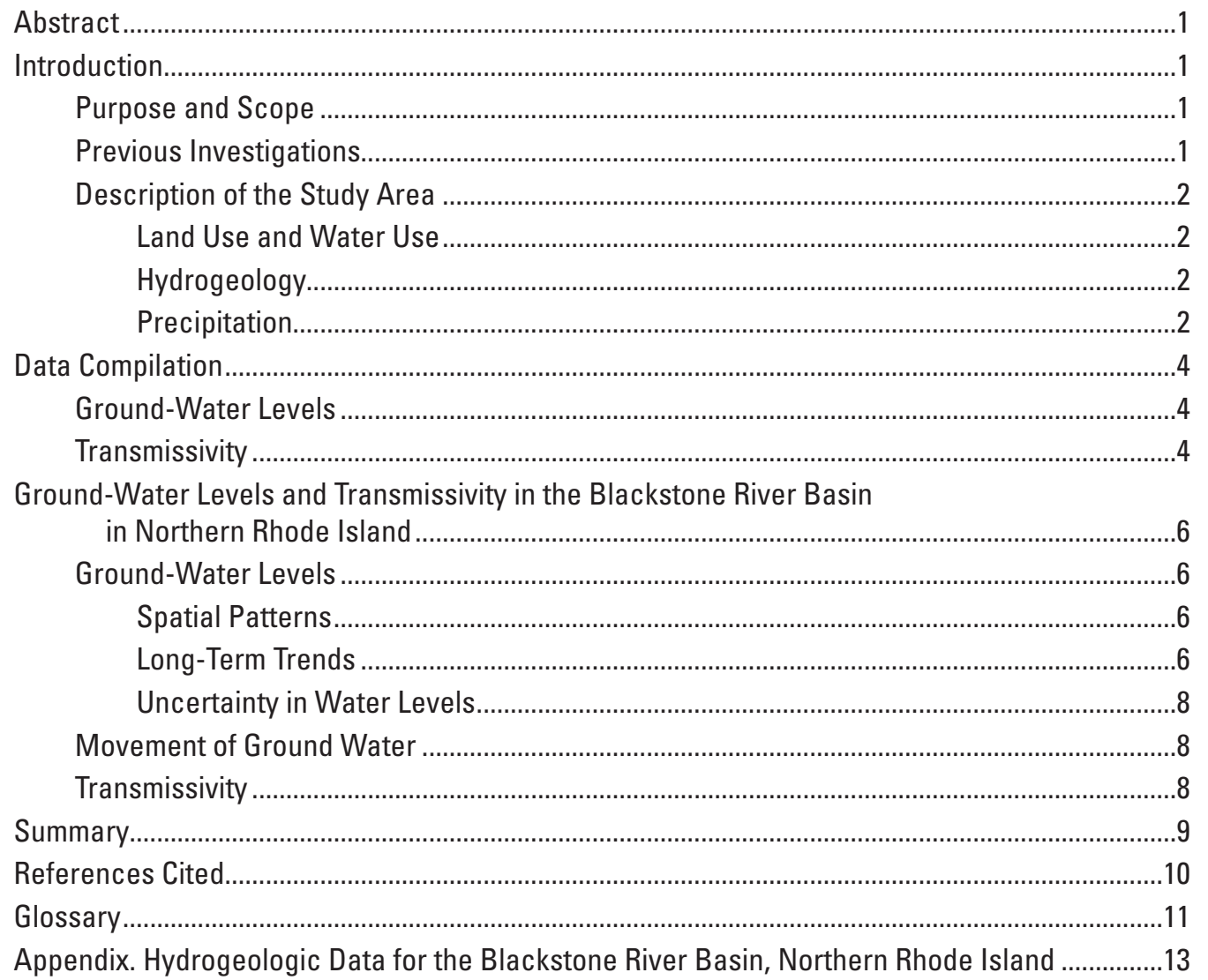

\section{Plates}

In pocket

1. Water-table altitudes in the Blackstone River Basin, northern Rhode Island

2. Aquifer transmissivity in the Blackstone River Basin, northern Rhode Island

\section{Figures}

1. Map showing Blackstone River Basin and study area, northern Rhode Island

2-4. Graphs showing-

2. Water-table altitudes for the 1940s through 2003 in wells RI-LIW-84, RI-CUW-265, RI-NSW-21, and RI-BUW-187, Blackstone River Basin, northern Rhode Island ......5

3. Seasonal changes in the altitude of the water table in North Smithfield well 21 (RI-NSW-21) for 1947-2003, Blackstone River Basin, northern

Rhode Island

4. Annual precipitation at climatological station 379423 in Woonsocket, Rhode Island for 1949-2003. 


\section{Tables}

1. Lithologic categories and assigned hydraulic conductivity values in the Blackstone River Basin, northern Rhode Island.

2. Descriptive statistics for transmissivity values in the Blackstone River Basin, northern Rhode Island

\section{Conversion Factors, Datums, and Abbreviations}

\begin{tabular}{lll}
\hline & Multiply & \multicolumn{1}{c}{ By obtain } \\
\hline foot (ft) & Length & \\
inch (in.) & 0.3048 & meter $(\mathrm{m})$ \\
mile (mi) & 2.54 & centimeter $(\mathrm{cm})$ \\
\hline & 1.609 & kilometer $(\mathrm{km})$ \\
\hline square mile $\left(\mathrm{mi}^{2}\right)$ & Area & \\
\hline & 2.590 & square kilometer $\left(\mathrm{km}^{2}\right)$ \\
\hline gallon $(\mathrm{gal})$ & Volume & \\
\hline & 3.785 & liter $(\mathrm{L})$ \\
\hline inch per year $(\mathrm{in} / \mathrm{yr})$ & Flow rate & \\
cubic foot per second $\left(\mathrm{ft}{ }^{3} / \mathrm{s}\right)$ & 2.54 & centimeter per year $(\mathrm{cm} / \mathrm{yr})$ \\
foot per day (ft/d) & .6464 & million gallons per day $(\mathrm{Mgal} / \mathrm{d})$ \\
foot per year $(\mathrm{ft} / \mathrm{yr})$ & .3048 & meter per day $(\mathrm{m} / \mathrm{d})$ \\
\hline & .3048 & meter per year $(\mathrm{m} / \mathrm{yr})$ \\
\hline foot squared per day $\left(\mathrm{ft}^{2} / \mathrm{d}\right)$ & Transmissivity & \\
\hline
\end{tabular}

Vertical coordinate information is referenced to the National Geodetic Vertical Datum of 1929 (NGVD 1929). Altitude, as used in this report, refers to distance above the vertical datum.

Horizontal coordinate information is referenced to the North American Datum of 1983 (NAD 83).

Transmissivity: The standard unit for transmissivity is cubic foot per day per square foot times foot of aquifer thickness [(ft $\left.\left.\mathrm{ft}^{3} / \mathrm{d}\right) / \mathrm{ft}^{2}\right] \mathrm{ft}$. In this report, the mathematically reduced form, foot squared per day $\left(\mathrm{ft}^{2} / \mathrm{d}\right)$, is used for convenience.

$\begin{aligned} \text { ABF } & \text { Aquatic Base Flow } \\ \text { ET } & \text { evapotranspiration } \\ \text { GWSI } & \text { Ground-Water Site Inventory } \\ \text { RIGIS } & \text { Rhode Island Geographic Information System } \\ \text { RIWRB } & \text { Rhode Island Water Resources Board } \\ \text { USGS } & \text { U.S. Geological Survey }\end{aligned}$




\title{
Long-Term Ground-Water Levels and Transmissivity in the Blackstone River Basin, Northern Rhode Island
}

\author{
By Jack R. Eggleston, Peter E. Church, and Jeffrey R. Barbaro
}

\section{Abstract}

Ground water provides about 7.7 million gallons per day, or 28 percent of total water use in the Rhode Island part of the Blackstone River Basin. Primary aquifers in the basin are stratified glacial deposits, composed mostly of sand and gravel along valley bottoms. The ground-water and surface-water system in the Blackstone River Basin is under stress due to population growth, out-of-basin water transfers, industrialization, and changing land-use patterns. Streamflow periodically drops below the Aquatic Base Flow standard, and groundwater withdrawals add to stress on aquatic habitat during low-flow periods.

Existing hydrogeologic data were reviewed to examine historical water-level trends and to generate contour maps of water-table altitudes and transmissivity of the sand and gravel aquifer in the Blackstone River Basin in Rhode Island. On the basis of data from four long-term observation wells, water levels appear to have risen slightly in the study area during the past 55 years. Analysis of available data indicates that increased rainfall during the same period is a likely contributor to the water-level rise. Spatial patterns of transmissivity are shown over larger areas and have been refined on the basis of more detailed data coverage as compared to previous mapping studies.

\section{Introduction}

The Blackstone River flows $46 \mathrm{mi}$ from its headwaters near Worcester, Massachusetts, the third largest city in New England, to the head of Narragansett Bay at Providence, Rhode Island, the second largest city in New England. About 126,600 people live in the Rhode Island part of the Blackstone River Basin (U.S. Census Bureau, 2000), and the population increased about 3.4 percent from 1990 to 2000. In addition to population growth, water transfers out of the basin, commercial and industrial growth, and changing land-use patterns have led to greater water use and stress on the water resources of the basin (Barlow, 2003). Ground water is an important source of water supply in the Rhode Island part of the Blackstone River Basin, providing about 7.7 Mgal/d, or
28 percent of total water use (Barlow, 2003). The U.S. Geological Survey (USGS), in cooperation with the Rhode Island Water Resources Board (RIWRB), is studying ground-water availability in the basin to help prepare for future population growth and increased water demand. This report focuses on the ground-water resources of the Blackstone River Basin in Rhode Island with a compilation and analysis of aquifer transmissivity and ground-water-level data. The results of this study can be used in developing water-resource management plans.

\section{Purpose and Scope}

This report presents an analysis of ground-water resources in the Rhode Island portion of the Blackstone River Basin. Spatial and temporal trends in ground-water levels, expressed as the altitude of the water table above the National Geodetic Vertical Datum (NGVD) of 1929, are analyzed and mapped. Available transmissivity data are used to compile a contour map that updates previous maps (Johnston and Dickerman, 1974a,b) and presents a broader regional view of transmissivity of the sand and gravel aquifer.

\section{Previous Investigations}

Water use and availability in the lower Blackstone River Basin, including the parts of the basin in both Rhode Island and Massachusetts, were documented by Barlow (2003). Ground water is withdrawn for private use and public watersupply use within the basin. An average of $2.12 \mathrm{Mgal} / \mathrm{d}$ of ground water was withdrawn for public supplies in the Rhode Island part of the Blackstone River Basin in 1995-1999 (Barlow, 2003, table 4). An additional 2.14 Mgal/d of ground water is estimated to supply private use, both domestic and commercial (Barlow, 2003, table 5, subtracting known surface water withdrawals). In 2003-2004, parts of the basin experienced low-flow conditions, with streamflow periodically dropping below the Aquatic Base Flow standard (ABF) (U.S. Fish and Wildlife Service, 1981). Withdrawals at wells have been shown to deplete streamflow, exacerbating effects on aquatic habitat during periods of low streamflow (Barlow, 2003).

Previous investigations have examined ground-water resources in part of the Blackstone River Basin in Rhode 
Island. Johnston and Dickerman examined ground-water availability and quality in the Branch River subbasin (1974a) and the eastern part of the Blackstone River Basin (1974b). Information from those reports was used in this study, in addition to information from the USGS Ground-Water Site Inventory (GWSI) database in the National Water Information System (http://waterdata.usgs.gov/nwis/), and unpublished well logs recorded by private drilling companies and by the USGS.

\section{Description of the Study Area}

The study area is the Blackstone River Basin in Rhode Island (fig. 1 and plate 1), which has a drainage area of 140 $\mathrm{mi}^{2}$; the entire Blackstone River Basin has a drainage area of $474 \mathrm{mi}^{2}$ in Rhode Island and Massachusetts. Nine towns are in the Rhode Island part of the basin: Burrillville, Central Falls, Cumberland, Glocester, Lincoln, North Smithfield, Pawtucket, Smithfield, and Woonsocket (fig. 1). Land-surface altitudes in the Rhode Island part of the basin range from sea level at the outlet of the basin to $804 \mathrm{ft}$ in the southwestern part of the basin. Topography is dominated by narrow river valleys bordered by relatively steep hills. The Blackstone River was once known as the "hardest working river in America," a reference to the many dams powering mills along the river.

The largest tributary to the Blackstone River in Rhode Island is the Branch River, which is formed by the confluence of the Clear River and the Chepachet River in the town of Burrillville. The Branch River has a drainage area of $91 \mathrm{mi}^{2}$, or 65 percent of the Blackstone River Basin in Rhode Island. The Branch River joins the Blackstone River in the northeastern corner of North Smithfield, about $1 \mathrm{mi}$ upstream from Woonsocket. The only other major tributary to the Blackstone River with drainage area in Rhode Island is Abbot Run, which joins the Blackstone River at the border between Cumberland and Central Falls, less than 2 mi upstream from the Seekonk River. Abbott Run has a drainage area of $28 \mathrm{mi}^{2}$, or 20 percent of the Blackstone River Basin in Rhode Island.

\section{Land Use and Water Use}

Land in the basin is mostly forested (53 percent), with the remainder composed of residential areas (19 percent), water/wetlands (14 percent), urban/industrial areas ( 9 percent), and agricultural lands (5 percent). Geospatial data describing land use, surface geology, and surface-water occurrence were compiled for this study.

All of the towns in the basin are at least partly supplied with water from public water-supply authorities. Water is withdrawn from a few surface-water reservoirs and from ground-water wells throughout the basin to meet water demands. Although the sand and gravel aquifer is the source of most ground-water supplies, till and bedrock deposits do supply ground water to numerous private wells. Barlow (2003) reported that surface-water and ground-water withdrawals in the Rhode Island part of the Blackstone River Basin averaged 27.7 Mgal/d during 1995-1999, with ground-water withdrawals constituting $7.7 \mathrm{Mgal} / \mathrm{d}$ or 28 percent of the total.

\section{Hydrogeology}

Unconsolidated stratified glacial deposits underlie 30 percent of the Blackstone River Basin in Rhode Island; the remainder of the basin has exposed bedrock ( 2 percent), till (64 percent), or open water (4 percent) at the land surface. The irregularly shaped valleys are filled with stratified glacial deposits ranging in grain size from clay to gravel. Coarsegrained sand and gravel form the primary aquifer deposits, which are thin, discontinuous, and unconfined (plate 1).

Due to high aquifer permeability and short ground-water travel distances to streams, typically less than 3,000 ft, water withdrawals from the sand and gravel aquifer can cause relatively rapid flow reductions in nearby streams. Although the sand and gravel aquifer is the principal source of ground-water supplies, small withdrawals also are made from wells in till and bedrock areas, generally from private wells supplying a single home or business.

The RIWRB has published a map of ground-water reservoirs, which are the parts of the state's sand and gravel aquifers that have the greatest potential for supplying ground water, a saturated thickness of $40 \mathrm{ft}$ or greater, and a transmissivity of $4,000 \mathrm{ft}^{2} / \mathrm{d}$ or greater (Rhode Island Statewide Planning Program,1979; Rhode Island Department of Environmental Management, 1991).

\section{Precipitation}

Precipitation in the basin increased from 1949 to 2003 , but averaged $46 \mathrm{in} / \mathrm{yr}$, based on records at the National Oceanographic and Atmospheric Administration (NOAA) climatological station 379423 in Woonsocket, Rhode Island (fig. 1). Evapotranspiration (ET) can be estimated from streamflow records for the Branch River streamflow-gaging station at Forestdale, R.I. (USGS station 01111500), which represents 91 $\mathrm{mi}^{2}$, the largest unregulated part of the Blackstone River Basin in Rhode Island. Streamflow at the Forestdale, R.I. station averages $25.9 \mathrm{in} / \mathrm{yr}$ based on mean annual streamflow from 1941 through 2003. If the difference between precipitation and streamflow is assumed to be lost to ET, then ET equals 20.1 in/yr, or 44 percent of precipitation, for the Branch River Basin. Recharge to the aquifer in the Branch River Basin is $19.0 \mathrm{in} / \mathrm{yr}$, or 41 percent of precipitation, based on a hydrograph separation estimate of base flow at the Forestdale station from 1941 to 2003. 


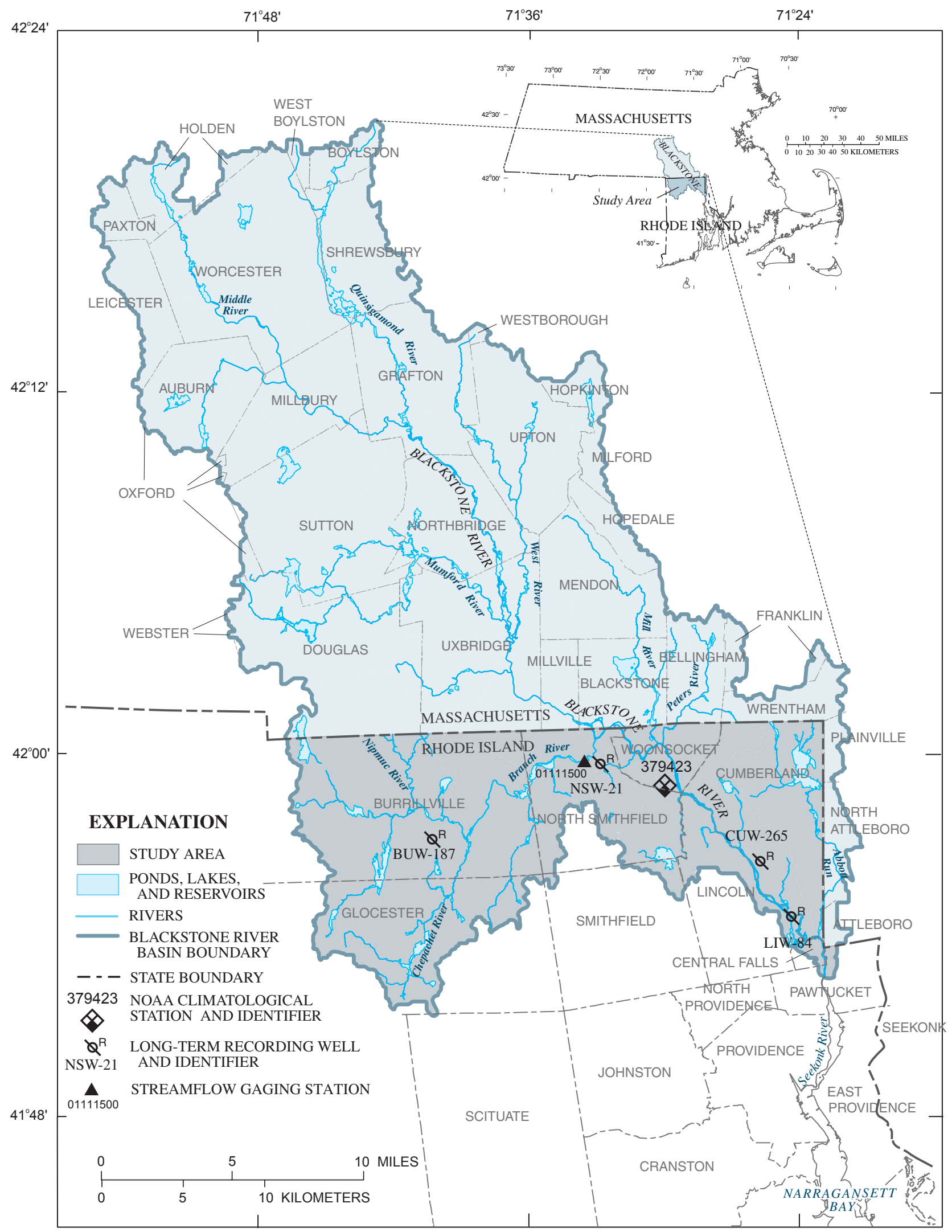

Base from the National Resource Conservation Service

12-digit HUC base map, 1:24,000, 2001

Projection: Rhode Island State Plane

1983 North American datum

Figure 1. Blackstone River Basin and study area, northern Rhode Island. 


\section{Data Compilation}

For this study, hydrogeologic data were compiled from previously published studies. A comprehensive literature search was conducted to find hydraulic conductivity, aquifer thickness, and ground-water-level data. The data were then formatted and organized in a database for ease of access and analysis. The Appendix contains the hydrogeologic data on which the mapping and analysis were based.

\section{Ground-Water Levels}

A contour map of the altitude of the water table in the sand and gravel aquifer was constructed on the basis of 726 water-level measurements made in wells (plate 1). The water levels were measured from 1900 to 2003 at various times of the year. In cases where water levels were measured more than once at a single well, the measurements were averaged.

Because the water table is close to the land surface throughout the Blackstone River Basin and the aquifer is unconfined, it is assumed that ground water is hydraulically connected to surface water. Therefore, altitudes of surfacewater bodies such as streams, ponds, and reservoirs were used to map the altitude of the water table. The altitudes of surface-water bodies and stream reaches were estimated from geospatial data obtained from the Rhode Island Geographic Information System (RIGIS). Altitudes at 15,815 surfacewater points were obtained in this manner and used to contour the water-table altitude.

Long-term, detailed, water-level records were compiled for four observation wells (RI-LIW-84, RI-CUW-265, RI-NSW-21, and RI-BUW-187) screened in the stratified glacial deposits (fig. 1). Periodic water-level measurements from the 1940s through 2003, obtained from the GWSI database, were used to develop time series of water-table altitudes for these wells (fig. 2).

\section{Transmissivity}

Transmissivity $(\mathrm{T})$ is a variable that expresses the ability of an aquifer to transmit water and indicates the suitability of an aquifer as a water-supply source. For this study, transmissivity values were determined by estimating saturated thickness (b) and hydraulic conductivity (K) from information in drilling logs. Drilling log records were obtained from previously published reports (Johnston and Dickerman, 1974a,b,c), from the GWSI database, and from unpublished water-well logs on file at the USGS Massachusetts-Rhode Island Water Science Center. The drilling logs contained 69 different descriptions of soil class/lithology. Each described lithology was placed in one of six categories and assigned a $\mathrm{K}$ value (table 1) based on earlier studies (Dickerman and Bell, 1993; Dickerman and others, 1990; Dickerman and others, 1997; Johnston and Dickerman, 1974a,b; Rosenshein and others, 1968). Silt, clay, till, and bedrock were assumed to have very low $\mathrm{K}$ of less than $10^{-4} \mathrm{ft} / \mathrm{d}$ and were assigned a value of zero when calculating transmissivity. Observed saturated intervals were recorded and $\mathrm{T}$ values were calculated using equation 1 below. In cases in which drilling logs did not indicate a water level, saturated thickness was calculated using a water-table altitude estimated from the contours shown on plate 1 .

$$
T=\sum_{i=1}^{n} b_{1} K_{i}
$$

where $n=$ number of lithologic units,

$i=$ lithologic unit indicator,

$b_{i}=$ saturated thickness of unit $i$, and

$K_{i}=$ hydraulic conductivity of unit $i$.

Equation 1 sums up the contribution to aquifer transmissivity from each permeable layer encountered when drilling a well. Values from 533 wells in the basin were used to construct a map of transmissivity of the sand and gravel aquifer. Transmissivity values greater than $50 \mathrm{ft}^{2} / \mathrm{d}$ are plotted on plate 2. Forty-eight percent of the transmissivity values were based on data from the Johnston and Dickerman studies (1974a,b,c).

Table 1. Lithologic categories and assigned hydraulic conductivity values in the Blackstone River Basin, northern Rhode Island.

$[<$, less than $]$

\begin{tabular}{lc}
\hline \multicolumn{1}{c}{ Lithologic category } & $\begin{array}{c}\text { Hydraulic conductivity, } \\
\text { in feet per day }\end{array}$ \\
\hline Silt, clay, till, and bedrock & $<10^{-4}$ \\
Silty sand & 10 \\
Fine to medium sand & 50 \\
Medium to coarse sand & 100 \\
Sand and gravel & 200 \\
Coarse gravel & 400 \\
\hline
\end{tabular}


RI-LIW-84
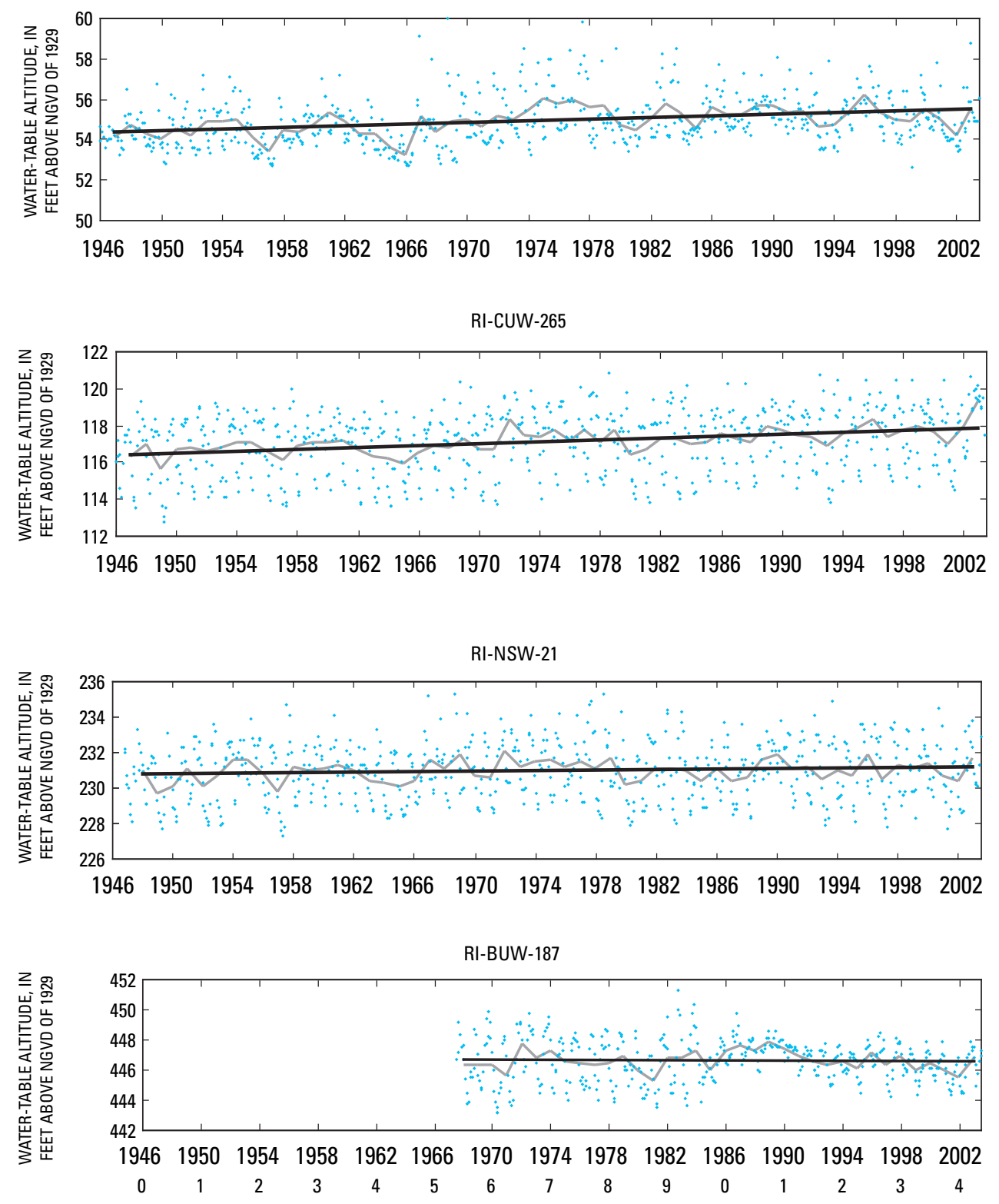

\section{EXPLANATION}

Annual average linear regression

Annual average watertable altitude

Water-table altitude

Figure 2. Water-table altitudes for the 1940s through 2003 in wells RI-LIW-84, RI-CUW-265, RI-NSW-21, and RI-BUW-187, Blackstone River Basin, northern Rhode Island. 


\section{Ground-Water Levels and Transmissivity in the Blackstone River Basin in Northern Rhode Island}

The water-level and transmissivity data were analyzed for spatial and temporal trends. The findings are discussed below with emphasis on their relation to water-supply availability.

\section{Ground-Water Levels}

The water level at any point in an aquifer can change over time. Periodic changes in ground-water levels occur in response to seasonal variations in precipitation and evapotranspiration. Other factors that can affect ground-water levels include changes in land use, ground-water and surface-water withdrawals, and wastewater disposal.

Changes in water levels in long-term observation well RINSW-21 give an example of typical seasonal patterns

(fig. 3) for the period 1947 to 2003 . Water levels in the aquifer are lowest during the late summer and early fall and highest during the early spring. Well RI-NSW-21 has an annual average water-level fluctuation of $3.6 \mathrm{ft}$, which is typical of wells in stratified glacial deposits.

\section{Spatial Patterns}

Water levels in the sand and gravel aquifer are higher in the western part of the study area where land-surface altitudes also are high. The highest ground-water levels in the study area, more than $700 \mathrm{ft}$ above NGVD 1929, are near Burlingame Reservoir in the town of Glocester. The lowest groundwater levels, less than $100 \mathrm{ft}$ above NGVD 1929, are near Central Falls, where the Blackstone River empties into the Seekonk River.

Water-table altitudes are affected by altitudes of nearby streams. Local patterns show that water-table altitudes decrease as ground water moves from ridge tops to valley bottoms. Near streams and lakes, water-table altitudes are nearly the same as surface-water altitudes.

\section{Long-Term Trends}

Water-table altitudes have risen in the study area from the 1940s through 2003; three of the four long-term observation wells in the basin show increasing altitudes and the fourth shows no trend (fig. 2). Annual average altitudes in wells CUW-265, LIW-84, and NSW-21 rose from the 1940s to 2003 by $1.1,1.4$, and $0.4 \mathrm{ft}$, respectively, whereas the altitude in BUW-187 declined $0.1 \mathrm{ft}$ between 1968 and 2003. Well NSW-

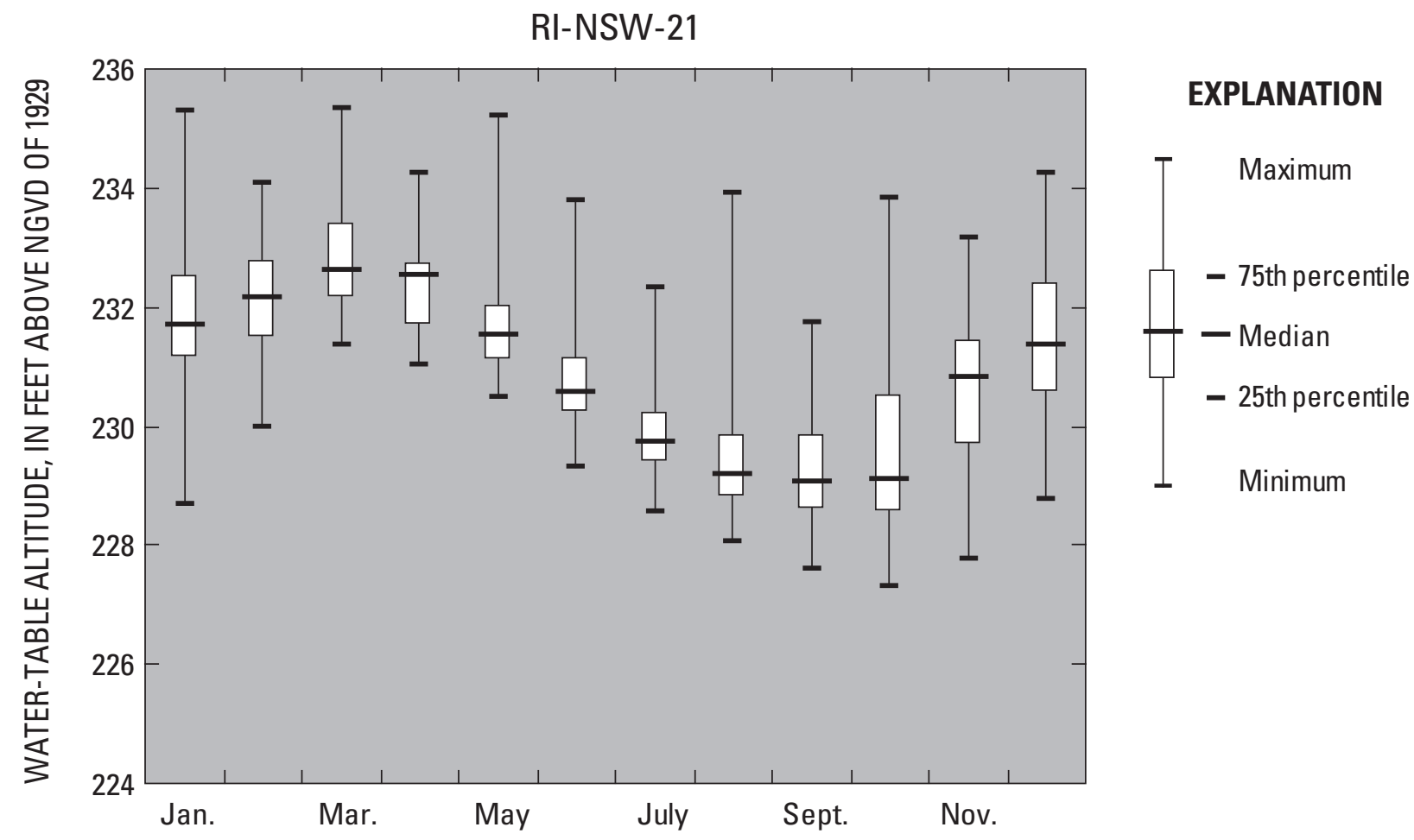

Figure 3. Seasonal changes in the altitude of the water table in North Smithfield well 21 (RI-NSW-21) for the 1940s through 2003, Blackstone River Basin, northern Rhode Island. Well location shown on figure 1 and plate 1. 
21 is reported to have been affected by pumping for domestic water supplies from 1947 to 1980 (Socolow and others, 2005).

Data describing land-use change, water withdrawals, evapotranspiration, and wastewater disposal during the past 60 years are insufficient to determine how these factors affected the altitude of the water table. A likely explanation for rising water-table altitudes is the precipitation increase in the Rhode Island part of the Blackstone River Basin (fig. 4). At climatological station 379423 in Woonsocket, R.I., the only long-term station in the basin, annual precipitation increased by about 11 in. from 1949 to 2003 (fig. 4) on the basis of a linear-trend fit to annual precipitation data (National Climate Data Center, 2003). Other stations within $20 \mathrm{mi}$ of the basin also show increased annual precipitation. Station 376698 in Providence, R.I., showed a change of +1.2 in. from 1949 to 2001; station 198367 in Taunton, Mass., showed a change of +7.8 in. from 1949 to 1993; and station 199316 in West Medway, Mass., showed a change of $+7.6 \mathrm{in}$. from 1957 to 2000 , based on linear-trend fits to annual precipitation data (National Climate Data Center, 2003). These long-term increases in Blackstone River Basin precipitation are further supported by streamflow records from 1929 to 2000 for the Blackstone River at the Woonsocket, R.I., (USGS station 01112500), which show an increase in streamflow of about 18 percent (Robinson and others, 2003).
The annual precipitation increase of about $11 \mathrm{in.} \mathrm{recorded}$ at Woonsocket would be expected to raise the ground-water level in the unconfined aquifers of the basin. A rough estimate of the expected ground-water-level rise caused by an increase in recharge can be obtained from a modification of the solution to Forchheimer's equation (Bear, 1972, eq. 8.2.26):

$$
m^{\prime}=N^{\prime} L^{2} / 8 K h_{0}
$$

where $m^{\prime}=$ change in ground-water level at groundwater divide (L),

$N^{\prime}=$ change in recharge rate $(\mathrm{L} / \mathrm{T})$,

$L=$ distance between drainages $(\mathrm{L})$,

$K=$ hydraulic conductivity $(\mathrm{L} / \mathrm{T})$, and

$h_{0}=$ height of drainage stage above the bottom of the aquifer (L).

Substituting $N^{\prime}=0.92 \mathrm{ft} / \mathrm{yr}$ (under the assumption that all additional precipitation goes to recharge), $L=2,430 \mathrm{ft}$ (an estimate of average distance between drainage streams obtained by dividing the basin area by $1.361 \times 10^{10} \mathrm{mi}$, the total length of stream centerlines in the study area), $K=100 \mathrm{ft} / \mathrm{d}$ (an estimate of average hydraulic conductivity based on the transmissivity data discussed above), and $h_{0}=40 \mathrm{ft}$ (an estimate of aquifer thickness below streams) yields

$$
m^{\prime}=0.5 \mathrm{ft} \text {. }
$$

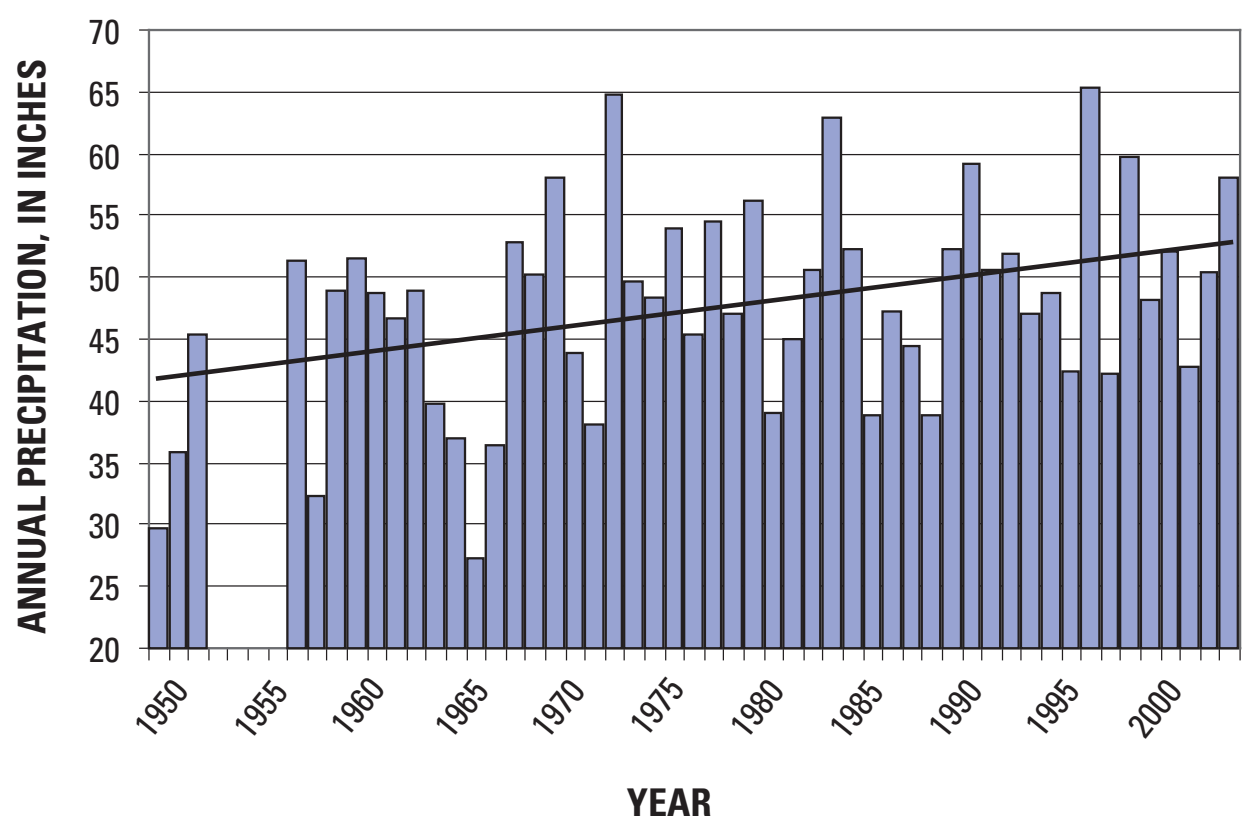

Figure 4. Annual precipitation at climatological station 379423 in Woonsocket, Rhode Island for 1949-2003. Straight line is the linear regression line. Location of station shown on figure 1 and plate 1. 
Equation 2 produces a calculated ground-water-level rise of $0.5 \mathrm{ft}$, which would occur halfway between two drainages (streams). Moving from a ground-water-level high toward a drainage, the ground-water-level rise would lessen and be zero at the drainage. The calculated rise of $0-0.5 \mathrm{ft}$ accounts for a part of the observed ground-water-level rises of 0 to $1.4 \mathrm{ft}$. So the observed ground-water-level rise is likely due in part to increased precipitation, but other factors are also probably contributing. More detailed study would be needed to confirm this hypothesis.

\section{Uncertainty in Water Levels}

Water levels were contoured for stratified glacial deposits in the study area (plate 1). Contours were initially produced with an automated routine and then checked and manually modified. Uncertainty in the water-table altitudes shown on the plate is due to the varied timing of the measurements, measurement errors, variations in water-table altitude with well depth, changes caused by pumping, and interpolation errors. Because water levels have risen over time, older measurements will tend to underestimate the current levels. Measurements were made during different seasons of the year, which adds further variability. The variation of water levels over time at one location is illustrated by measurements at well RI-NSW 21. Based on 685 water-level measurements taken from the 1940s through 2003 (fig. 3), the difference between maximum and minimum individual values is $8.0 \mathrm{ft}$ and the difference between maximum and minimum monthly mean values (March-September) is $3.7 \mathrm{ft}$.

Further assessment of uncertainty can be made by comparing water levels measured in closely spaced wells. There are 298 pairs of water-level measurements made at varying times in wells less than $100 \mathrm{ft}$ apart horizontally. Levels measured less than $100 \mathrm{ft}$ apart horizontally in the same aquifer are expected to agree quite closely, for example with a difference of less than $3 \mathrm{ft}$, unless there is nearby ground-water pumping, the wells are in steep terrain, or the wells are screened at different depths. For each of the 298 well pairs, water levels were subtracted from each other, yielding 298 differences. The average water-level difference is $15.5 \mathrm{ft}$ and the standard deviation is $24.7 \mathrm{ft}$. Using these differences as an indication of uncertainty in water levels suggests that the actual level can be expected to vary from the mapped level, at any point, by $15 \mathrm{ft}$ (plate 1).

\section{Movement of Ground Water}

Ground water in the study area flows towards major streams and rivers, which occupy regional topographic lows. The direction of ground-water flow, inferred from the contours of the altitude of the water table, is indicated by black arrows on plate 1. Ground water generally discharges to streams, ponds, and wetlands unless flowing to a pumped well. Exceptions to this pattern may be found locally where a stream crosses a transition to more permeable aquifer sediments, causing the stream to lose water to the aquifer and ground water to flow away from the stream. No such transitions are seen on plate 1 , in part because the spatial scale is too coarse to show such local effects.

\section{Transmissivity}

For a given aquifer thickness, transmissivity is controlled by lithology. Sand and gravel deposits generally have higher transmissivity than fine-grained stratified glacial deposits, till deposits, or bedrock. Estimated transmissivity values in the study area range from near zero to more than $25,000 \mathrm{ft}^{2} / \mathrm{d}$. Of the total of 553 transmissivity values, 152 (28 percent) are less than $50 \mathrm{ft}^{2} / \mathrm{d}$. Transmissivity values less than $50 \mathrm{ft}^{2} / \mathrm{d}$ are mainly in areas where bedrock or till is at the land surface. Statistics for the 390 transmissivity values in the sand and gravel aquifer are shown in table 2 .

Table 2. Descriptive statistics for transmissivity values in the sand and gravel aquifer, Blackstone River Basin, northern Rhode Island.

$[<$, less than $]$

\begin{tabular}{lc}
\hline Statistic & $\begin{array}{c}\text { Transmissivity, in feet } \\
\text { squared per day }\end{array}$ \\
\hline Count & 390 \\
Mean & 4,420 \\
Minimum & $<50$ \\
$10^{\text {th }}$ percentile & 200 \\
$25^{\text {th }}$ percentile & 1,000 \\
Median & 2,990 \\
$75^{\text {th }}$ percentile & 6,690 \\
$90^{\text {th }}$ percentile & 10,980 \\
Maximum & 22,650 \\
\hline
\end{tabular}


Transmissivity values greater than approximately 1,400 $\mathrm{ft}^{2} / \mathrm{d}$ "represent good aquifers for water well exploitation" (Freeze and Cherry, 1979, p. 60). Of the 357 transmissivity values in the sand and gravel aquifer greater than $50 \mathrm{ft}^{2} / \mathrm{d}, 74$ percent of the values are greater than $1,400 \mathrm{ft}^{2} / \mathrm{d}$.

Spatial patterns of transmissivity are predominately controlled by the thickness of stratified glacial deposits. The greatest transmissivity values are seen in the valleys of the Branch, Chepachet, Nipmuc, and Blackstone Rivers, where deep sand and gravel deposits are found (plate 2) and where wells may induce infiltration from surface-water bodies. Transmissivity values greater than $10,000 \mathrm{ft}^{2} / \mathrm{d}$ are seen in every town in the study area except Smithfield, within which no transmissivity measurements were made within the study area, and which has very little area with stratified glacial deposits. Based on the contours on plate 2 , the stratified glacial deposits in about $22 \mathrm{mi}^{2}$, or 16 percent of the study area, have transmissivity values greater than $1,000 \mathrm{ft}^{2} / \mathrm{d}$.

Although plates 1 and 2 do not show contours of watertable altitude or transmissivity in areas of till and bedrock, ground water is present in these areas. Areas of till and bedrock generally have lower transmissivity values and well yields, but some water-supply wells are located in these areas to serve small communities, small businesses, or private households. This study does not include an analysis of till and bedrock areas and should not be used to infer transmissivity values or ground-water levels for such areas.

Because the transmissivity map in this study is based on most of the same data used by Johnston and Dickerman (1974a,b) to construct their transmissivity maps, there are many similarities between the maps. Of the 533 transmissivity values used to construct plate 2, 48 percent, or 256 values, were also used by Johnston and Dickerman. Differences between plate 2 and the 1974 maps include the display of transmissivity point data, display of the entire Rhode Island part of the Blackstone River Basin, and modified transmissivity contours in those areas where additional transmissivity data were available. Areas of high transmissivity (greater than $5,000 \mathrm{ft}^{2} / \mathrm{d}$ ) on plate 2 differ somewhat from the ground-water reservoirs identified by the state of Rhode Island (Rhode Island Statewide Planning Program,1979; Rhode Island
Department of Environmental Management, 1991). Along the Blackstone River in the southern part of Cumberland and in the Chepachet River valley, the new map shows less extensive areas of high transmissivity. In other parts of the basin, such as near the Pascoag and Wilson Reservoirs, the areas of high transmissivity are more extensive than the previously mapped ground-water reservoirs.

\section{Summary}

This study of ground-water resources in the Rhode Island portion of the Blackstone River Basin was performed in cooperation with the Rhode Island Water Resources Board. Spatial and temporal trends in ground-water levels are presented, and transmissivity data are compiled into a contour map that presents a more regional view of aquifer transmissivity than do previous maps.

Ground-water levels rose in the study area from 1947 to 2003. Water levels are known to decline locally near pumping wells, but these declines are limited in areal extent by the narrow geometry of the sand and gravel aquifers and the proximity of surface water to most wells in the study area. The measured increase in precipitation rate, about 11 inches per year from 1949 to 2003 in Woonsocket, R.I., is likely a contributor to the observed water-level increases. Data from four wells with long-term water-level records have good temporal detail, but because long-term data are available from only a small number of wells in the study area, it is not known if water levels have risen throughout the watershed.

Transmissivity is greatest in areas of thick sand and gravel deposits, which typically occur in stream valley bottoms. Some high-transmissivity wells are seen in areas not previously identified by the state of Rhode Island as groundwater reservoirs. Other areas show lower transmissivity than the previously mapped ground-water reservoirs. The contours in plate 2 and wells listed in the Appendix give more detailed and more accessible information about transmissivity than has previously been available for the Blackstone River Basin in Rhode Island. 


\section{References Cited}

Barlow, L.K., 2003, Estimated water use and availability in the lower Blackstone River Basin, northern Rhode Island and south-central Massachusetts, 1995-1999: U.S. Geological Survey Water-Resources Investigations Report 03-4190, $75 \mathrm{p}$.

Bear, J., 1972, Dynamics of fluids in porous media: New York, Dover Publications, 764 p.

Dickerman, D.C., and Bell, R.W., 1993, Hydrogeology, water quality, and ground-water development alternatives in the Upper Wood River ground-water reservoir, Rhode Island: U.S. Geological Survey Water-Resources Investigations Report 92-4119, 87 p.

Dickerman, D.C., Trench, E.C.T., and Russell, J.P., 1990, Hydrogeology, water quality and ground-water development alternatives in lower Wood River ground-water reservoir, Rhode Island: U.S. Geological Survey Water-Resources Investigations Report 89-4031, 109 p.

Dickerman, D.C., Kliever, J.D., Stone, J.R., 1997, Hydrogeology, water quality, and simulation of ground-water development alternatives in the Usquepaug-Queen ground-water reservoir, Rhode Island: U.S. Geological Survey WaterResources Investigations Report 97-4126, 48 p.

Freeze, R.A., and Cherry, J.A., 1979, Groundwater: Englewood Cliffs, NJ, Prentice Hall, 604 p.

Johnston, H.E., and Dickerman, D.C., 1974a, Availability of ground water in the Branch River basin, Providence County, Rhode Island: U.S. Geological Survey Water-Resources Investigations Report 18-74, 39 p.

Johnston, H.E., and Dickerman, D.C., 1974b, Availability of ground water in the Blackstone River area, Rhode Island and Massachusetts: U.S. Geological Survey WaterResources Investigations Report 4-74, 1 pl.

Johnston, H.E., and Dickerman, D.C., 1974c, Geologic and hydrologic data for the Blackstone River area, Rhode Island, U.S. Geological Survey Hydrologic Bulletin 7, 44 p.
National Climate Data Center, Annual climatological summary, 1948-2003, accessed on Jan. 3, 2005, at http://www. ncdc.noaa.gov/oa/mppsearch.html

Rhode Island Department of Environmental Management, 1991, Policies and procedures for mapping recharge areas to groundwater reservoirs for GAA classification: Providence, Rhode Island, memorandum, unnumbered.

Rhode Island Statewide Planning Program, 1979, Water quality management plan for Rhode Island-Final plan, August, 1979: Providence, Rhode Island, 468 p.

Robinson, K.W., Campbell, J.P., and Jaworski, N.A., 2003, Water-quality trends in New England rivers during the 20th century: U.S. Geological Survey Water-Resources Investigations Report 03-4012, 20 p.

Rosenshein, J.S., Gonthier, J.B., and Allen, W.B., 1968, Hydrologic characteristics and sustained yield of principal ground-water units, Potowomut-Wickford area, Rhode Island: U.S. Geological Survey Water-Supply Paper 1775, $38 \mathrm{p}$.

Socolow, R.S., Comeau, L.Y., and Domenic Murino, Jr., 2005, Water resources data for Massachusetts and Rhode Island, water year 2004: U.S. Geological Survey Water-Data Report MA-RI-04-1, 326 p.

U.S. Fish and Wildlife Service, 1981, Interim regional policy for New England stream flow recommendations: Memorandum from H.N. Larsen, Director, Region 5, U.S. Fish and Wildlife Service, Newton Corner, Massachusetts, 3 p.

U.S. Census Bureau, 2000, Census 2000, accessed on Jan. 4, 2005 at http://www.census.gov/. 


\section{Glossary}

aquifer An underground formation of earth, sand, gravel, or porous stone that yields significant quantities of water to wells or springs.

base flow The water in streams and rivers that has come from ground-water discharge. During periods of little or no precipitation, typically all the water in a stream is base flow.

confined aquifer An aquifer that is covered by a layer of impermeable material, such as rock or clay, so that the water level in a well rises above the top of the aquifer.

evapotranspiration The movement of water from the land surface to the atmosphere. The word is formed by combining "evaporation," meaning the conversion of water from fluid to vapor, and "transpiration," meaning the release of water vapor to the atmosphere by plants. transmissivity A measure of the ability of an aquifer to transmit water; indicates the suitability of an aquifer as a water source. Units are length squared/time, for instance feet squared per day.

unconfined aquifer An aquifer not covered by an impermeable layer in which the water table forms the upper boundary. At the water table the pressure of the water equals the pressure of the atmosphere.

unconsolidated Refers to loose materials such as sand, gravel, and clay that are not cemented together, as opposed to solid rock. 

Appendix. Hydrogeologic Data for the
Blackstone River Basin, Northern Rhode Island 


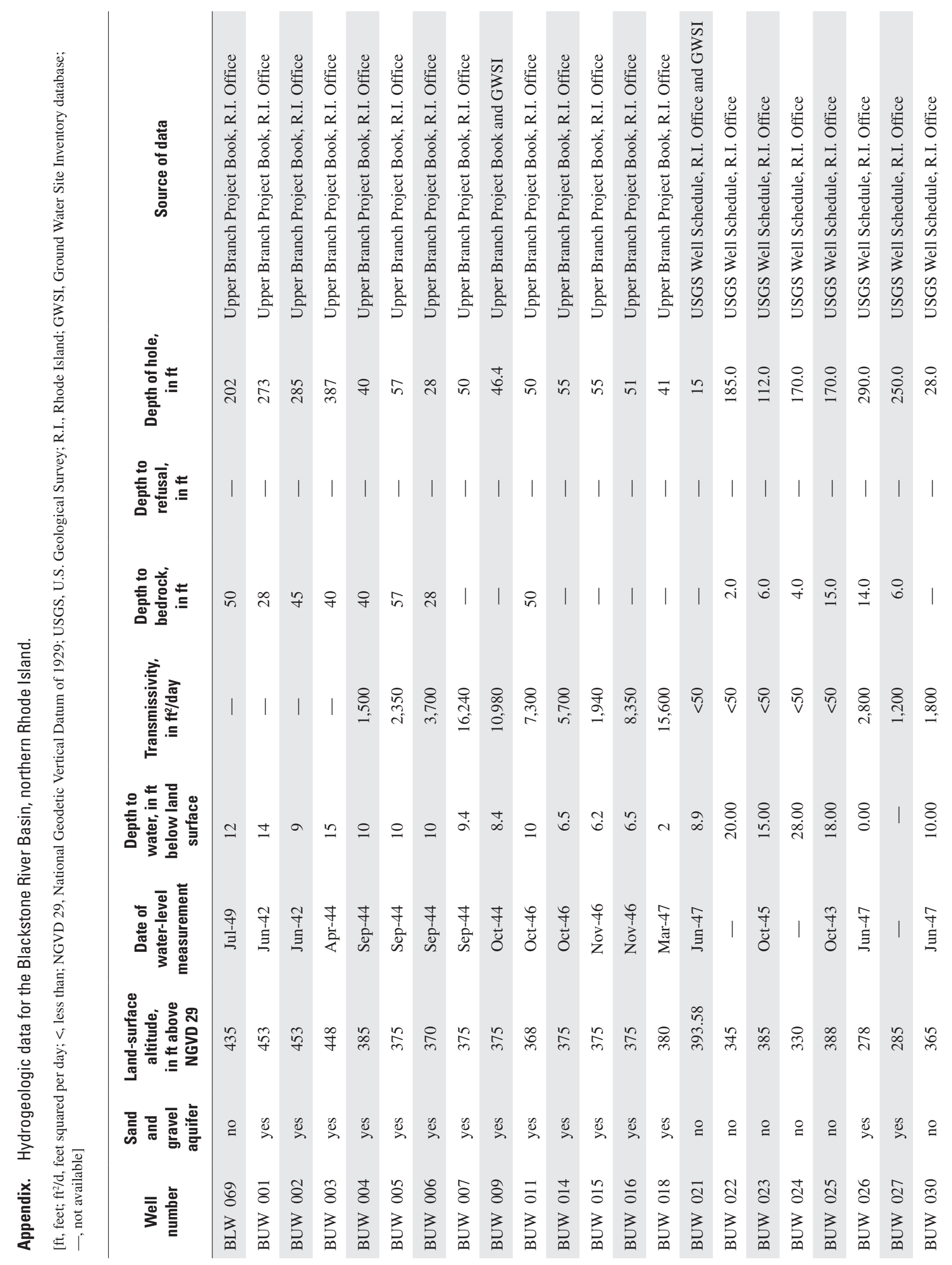




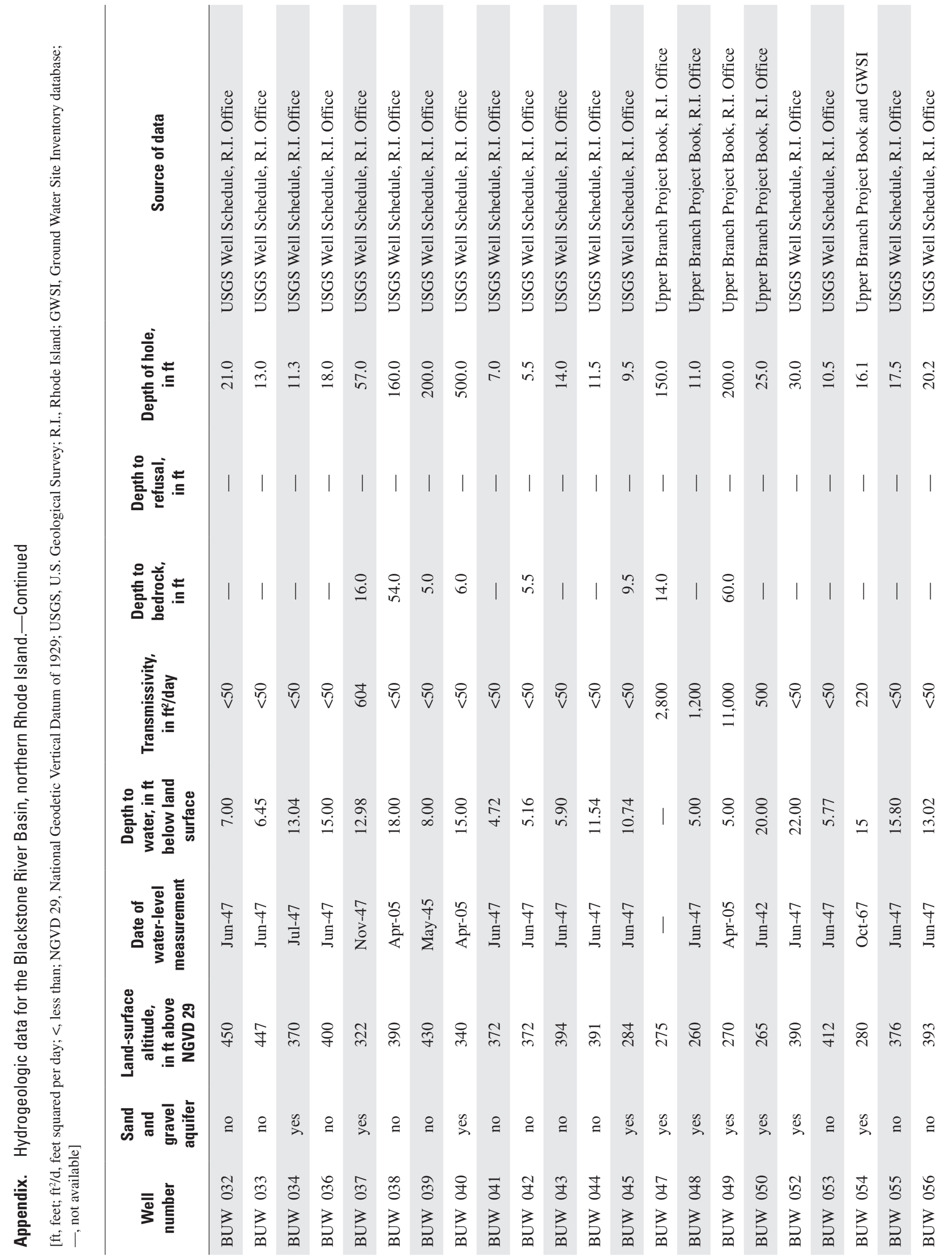




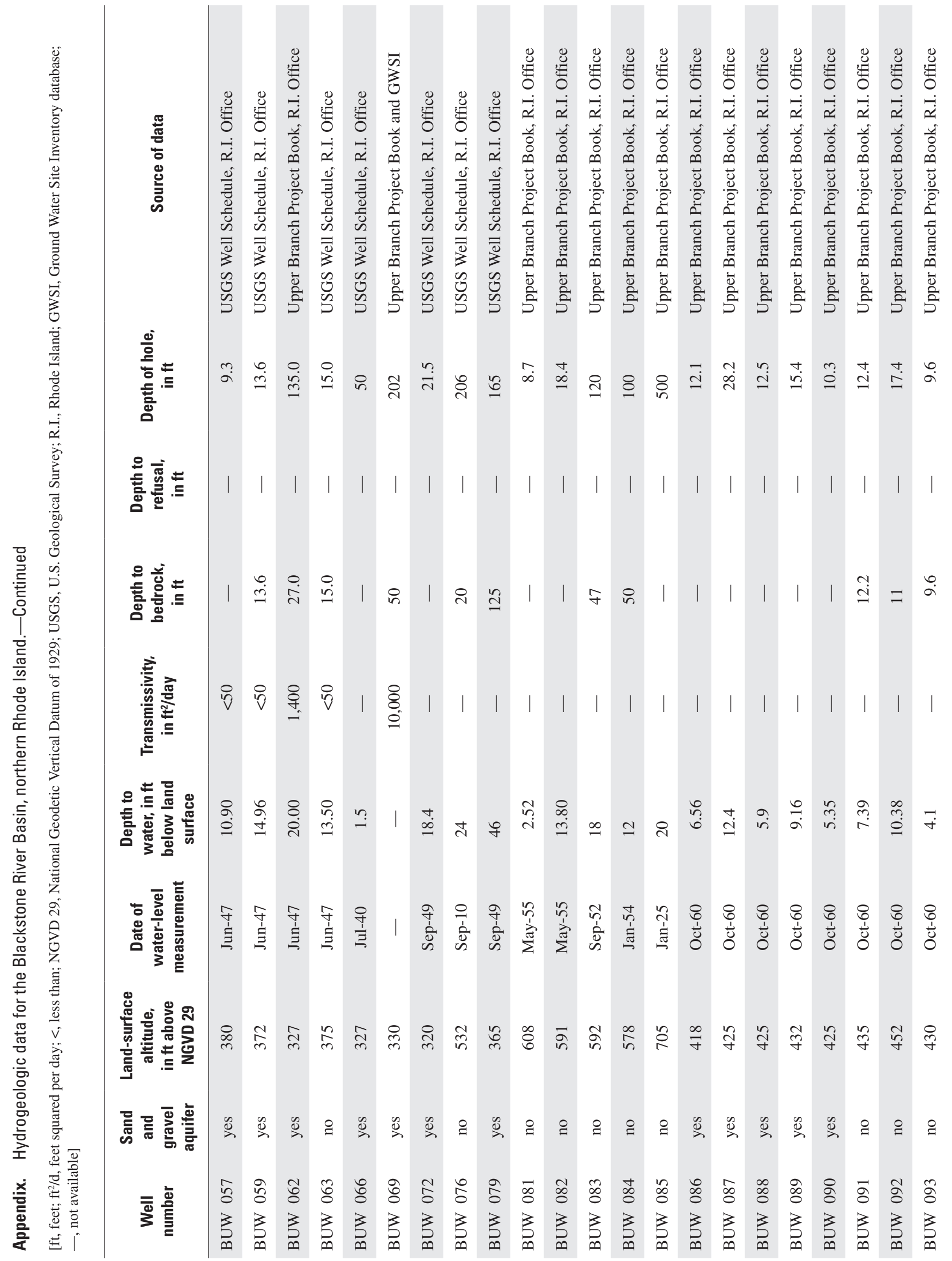




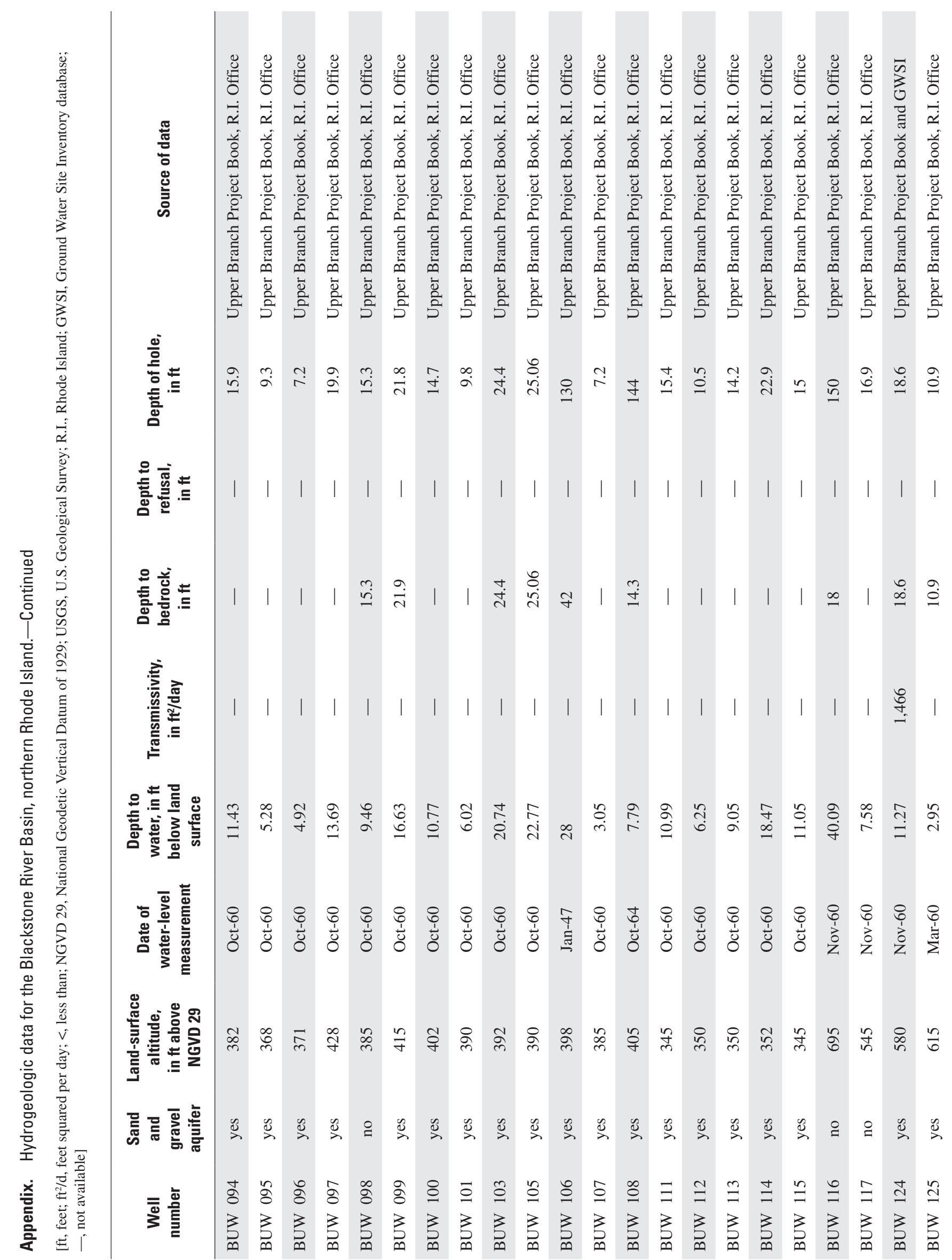




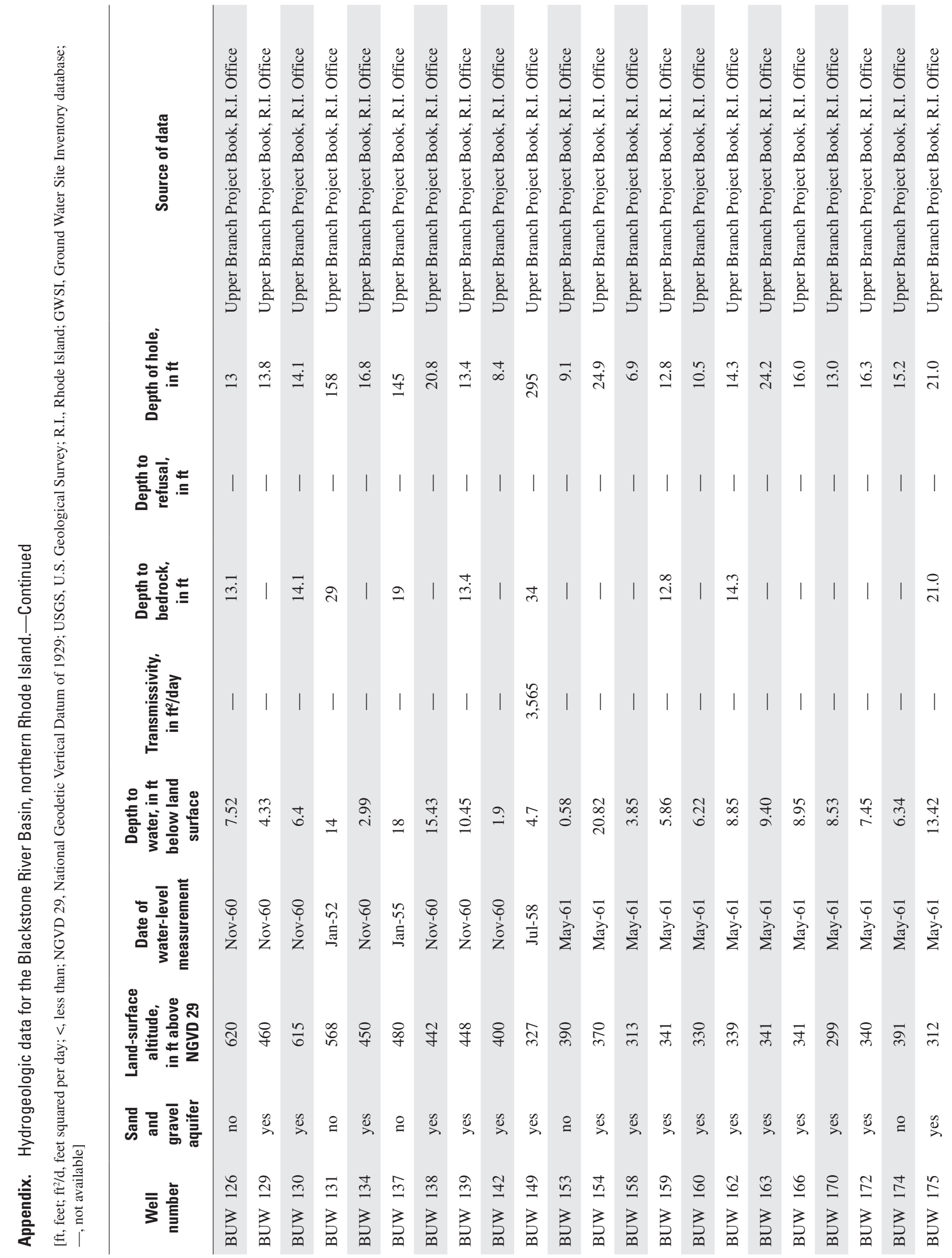




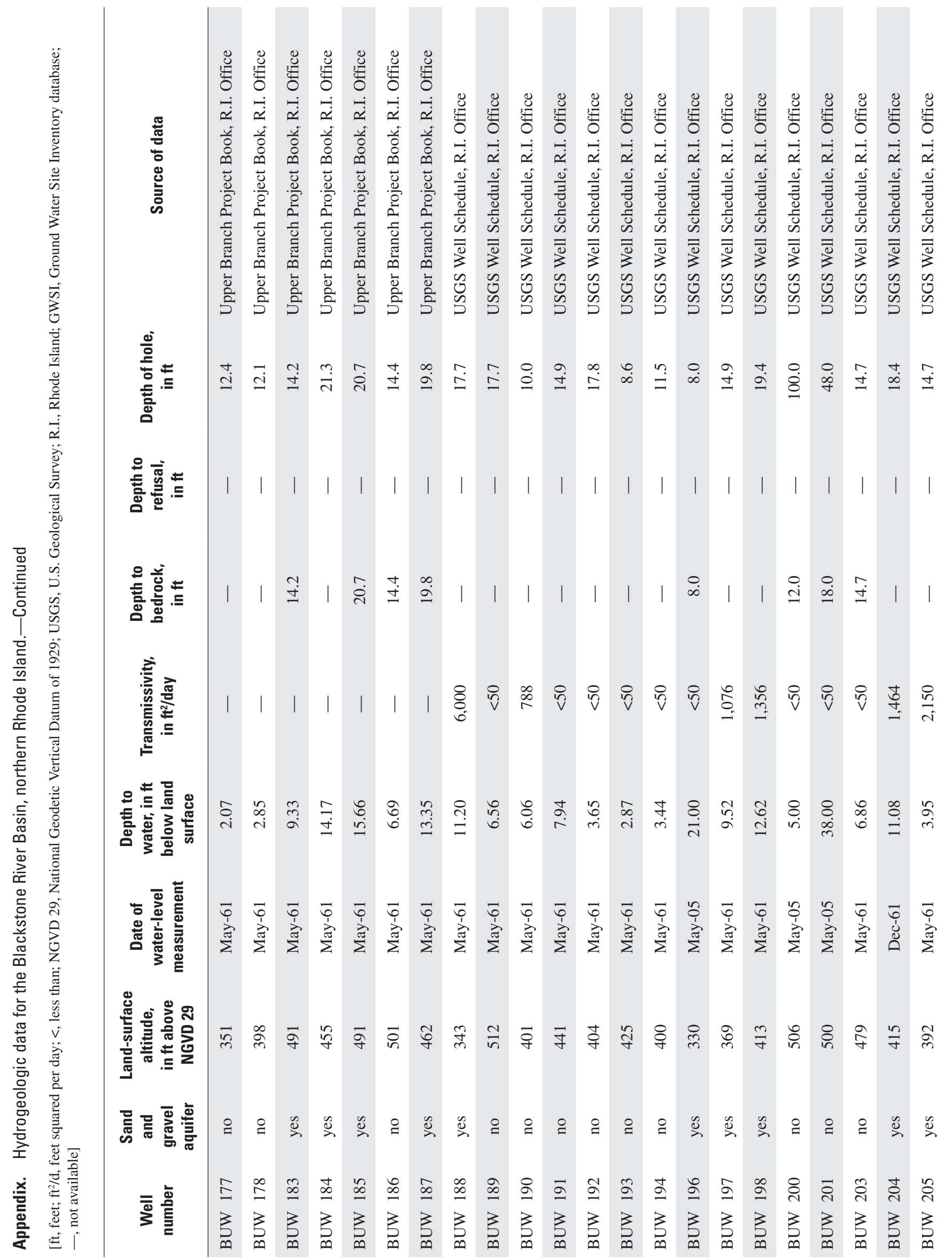




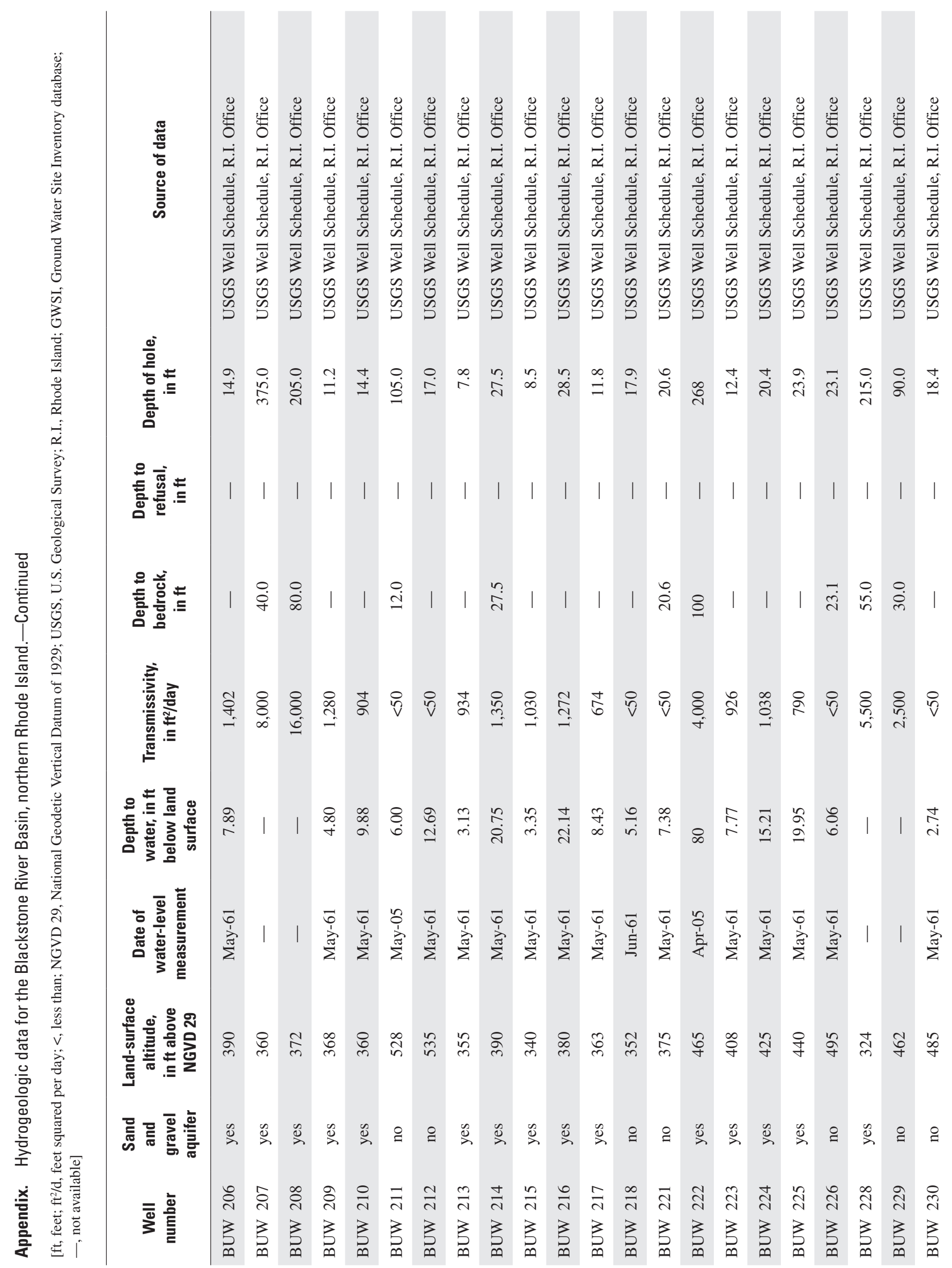




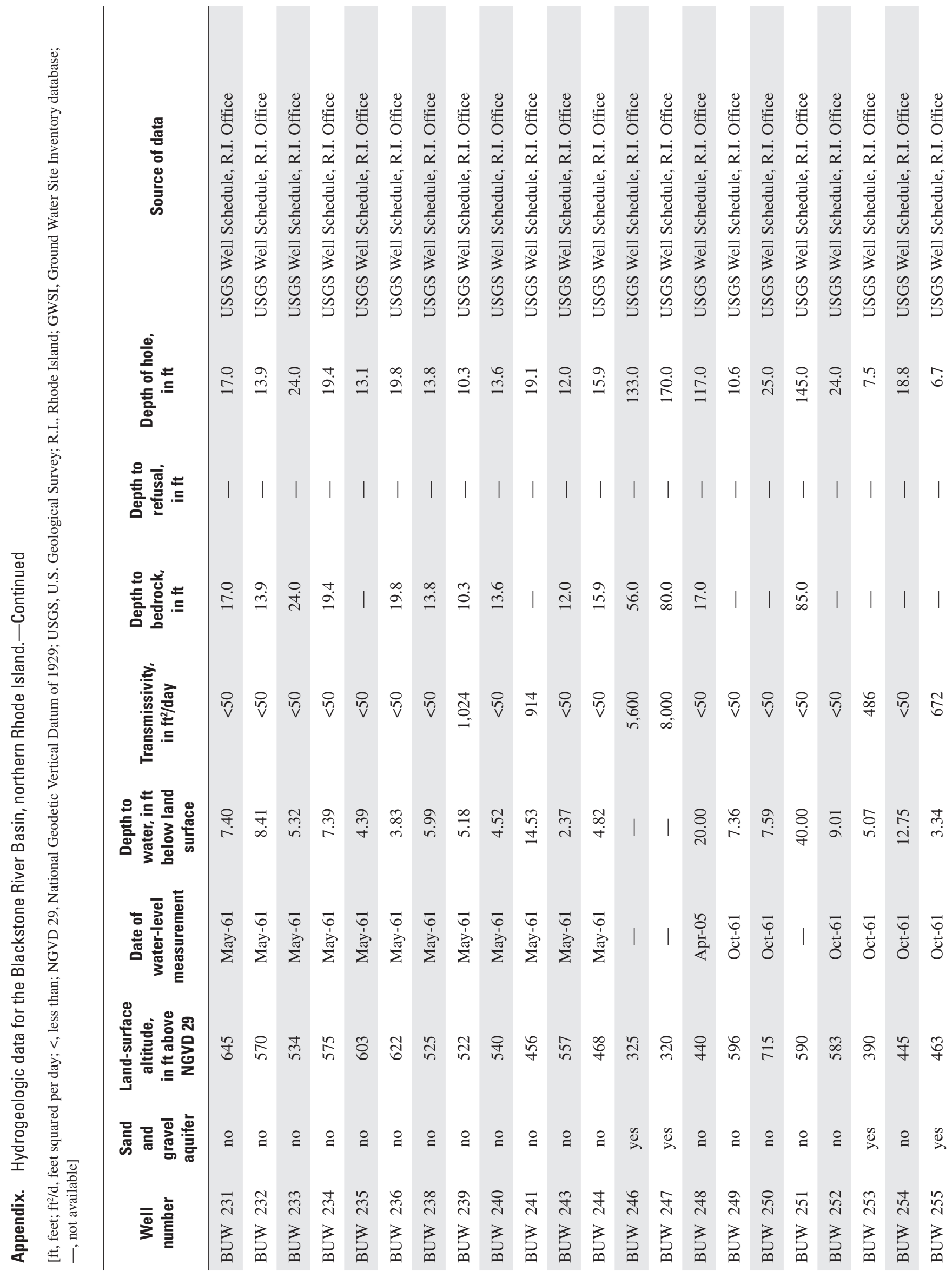




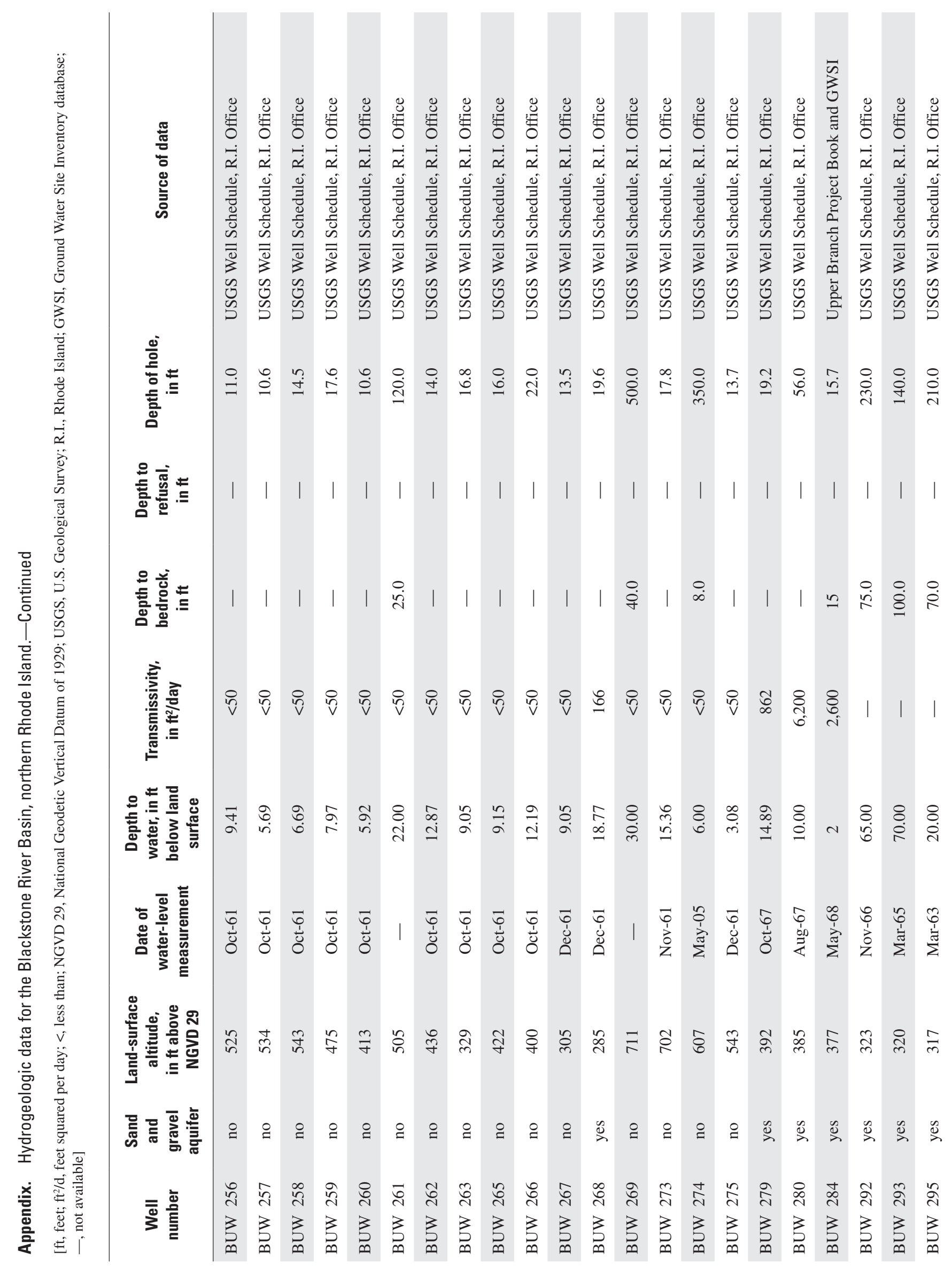




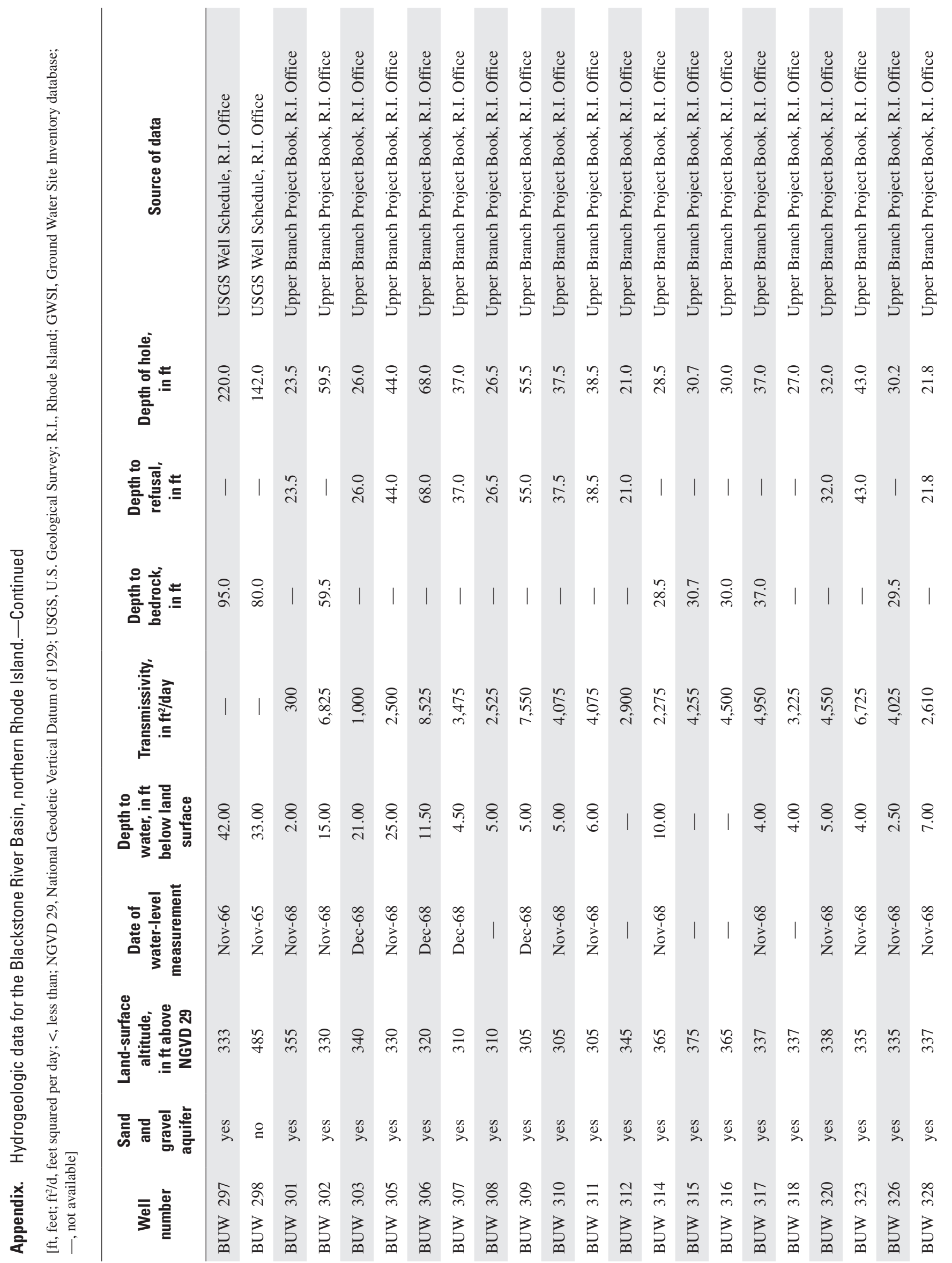




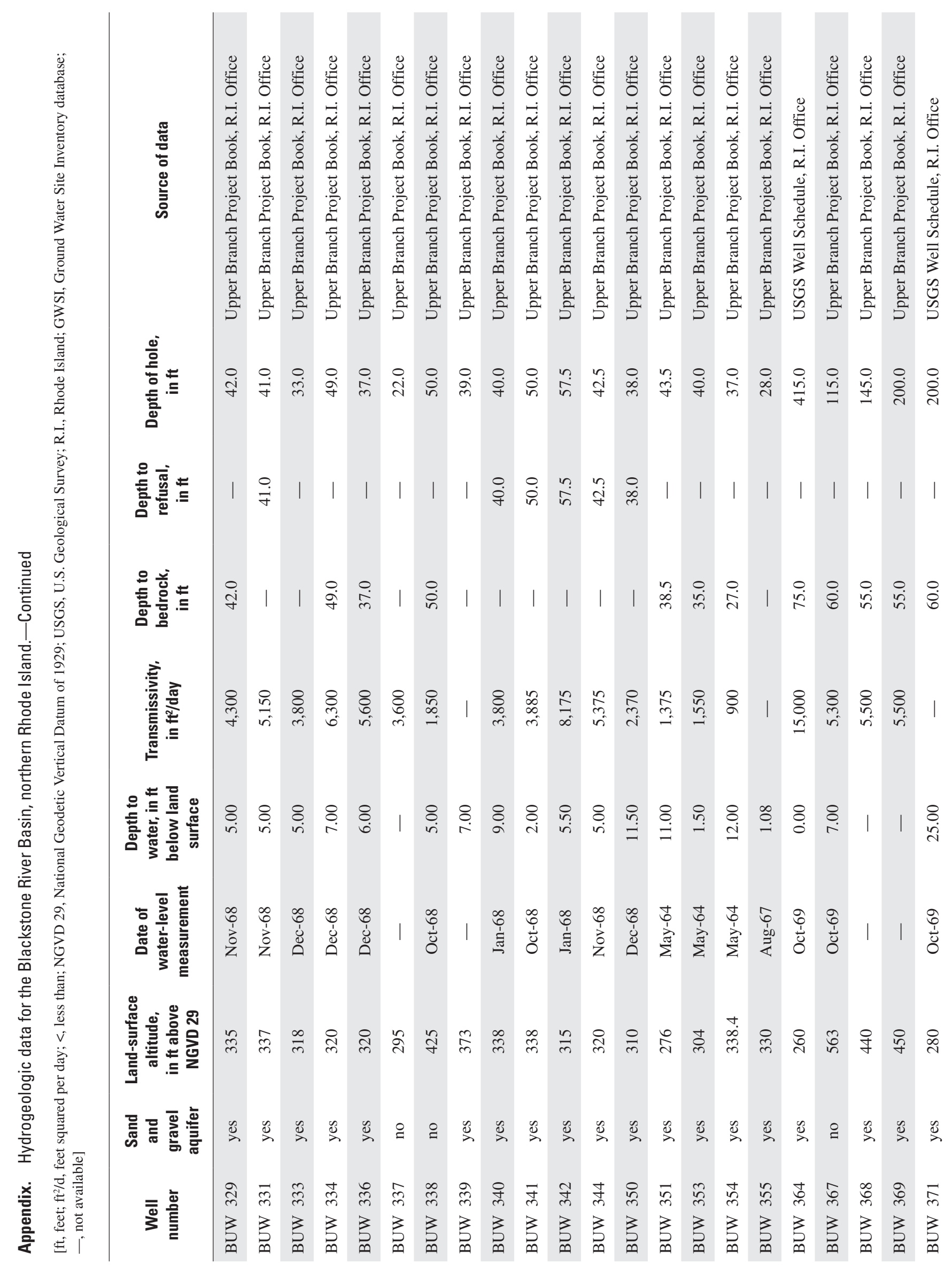




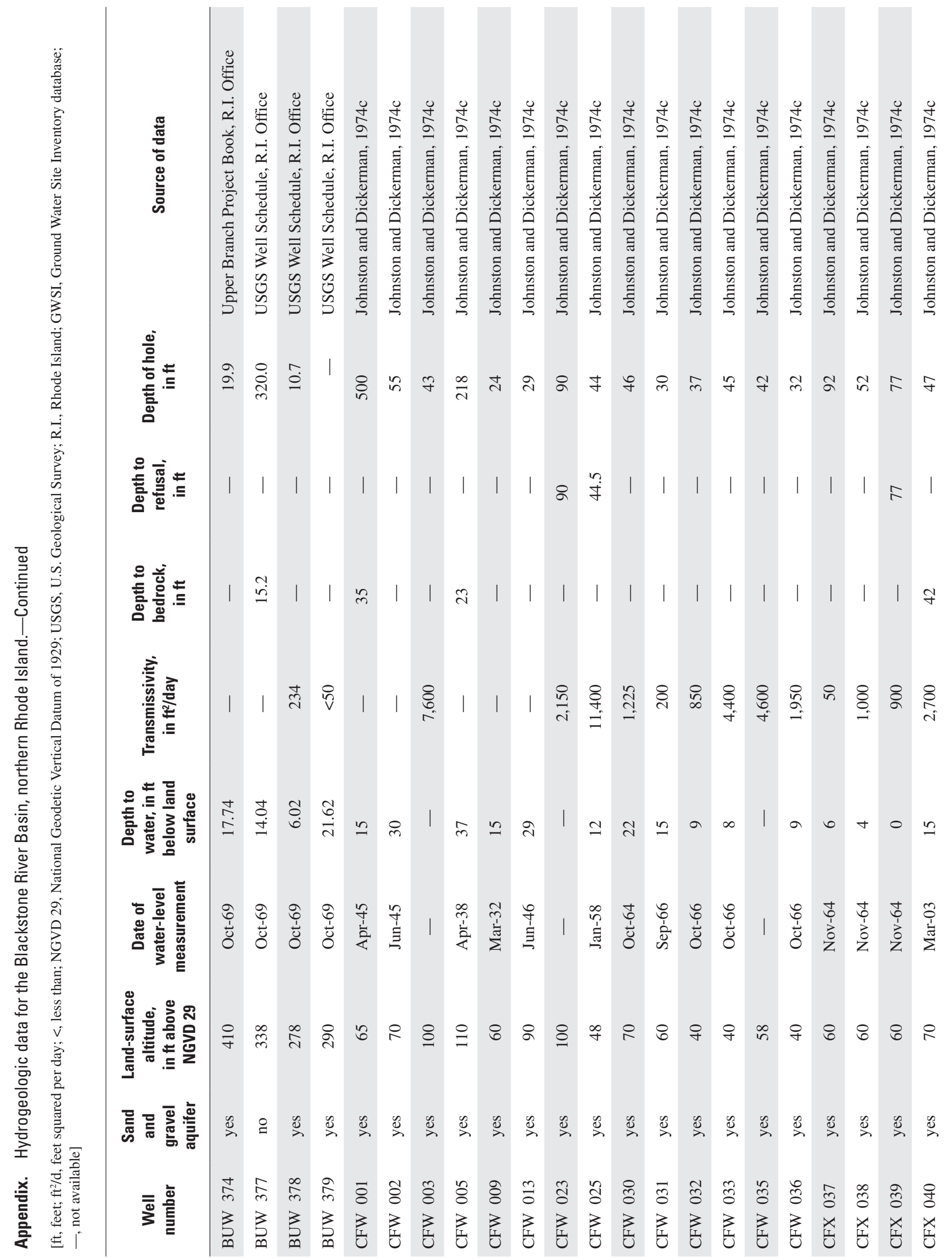




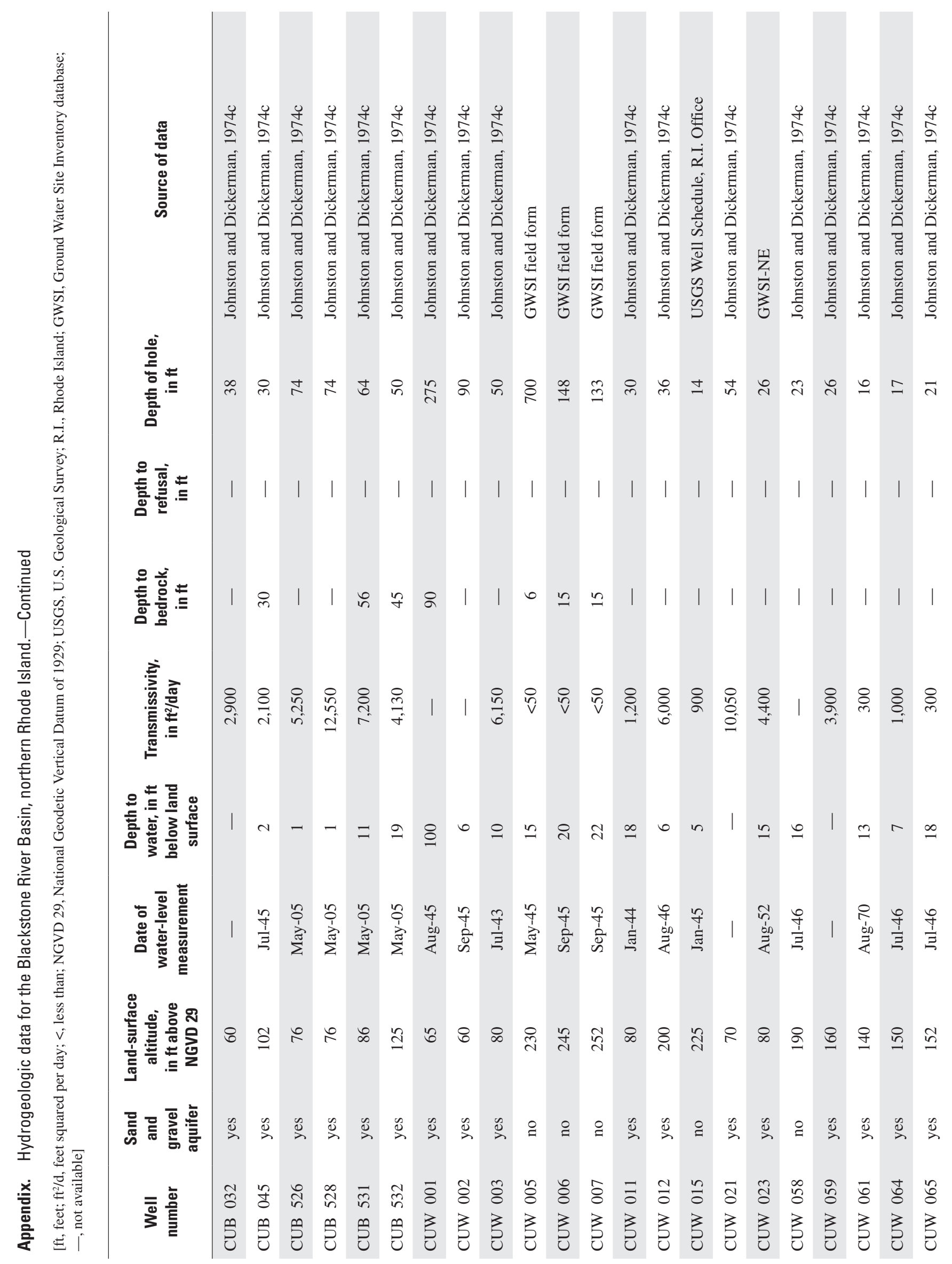




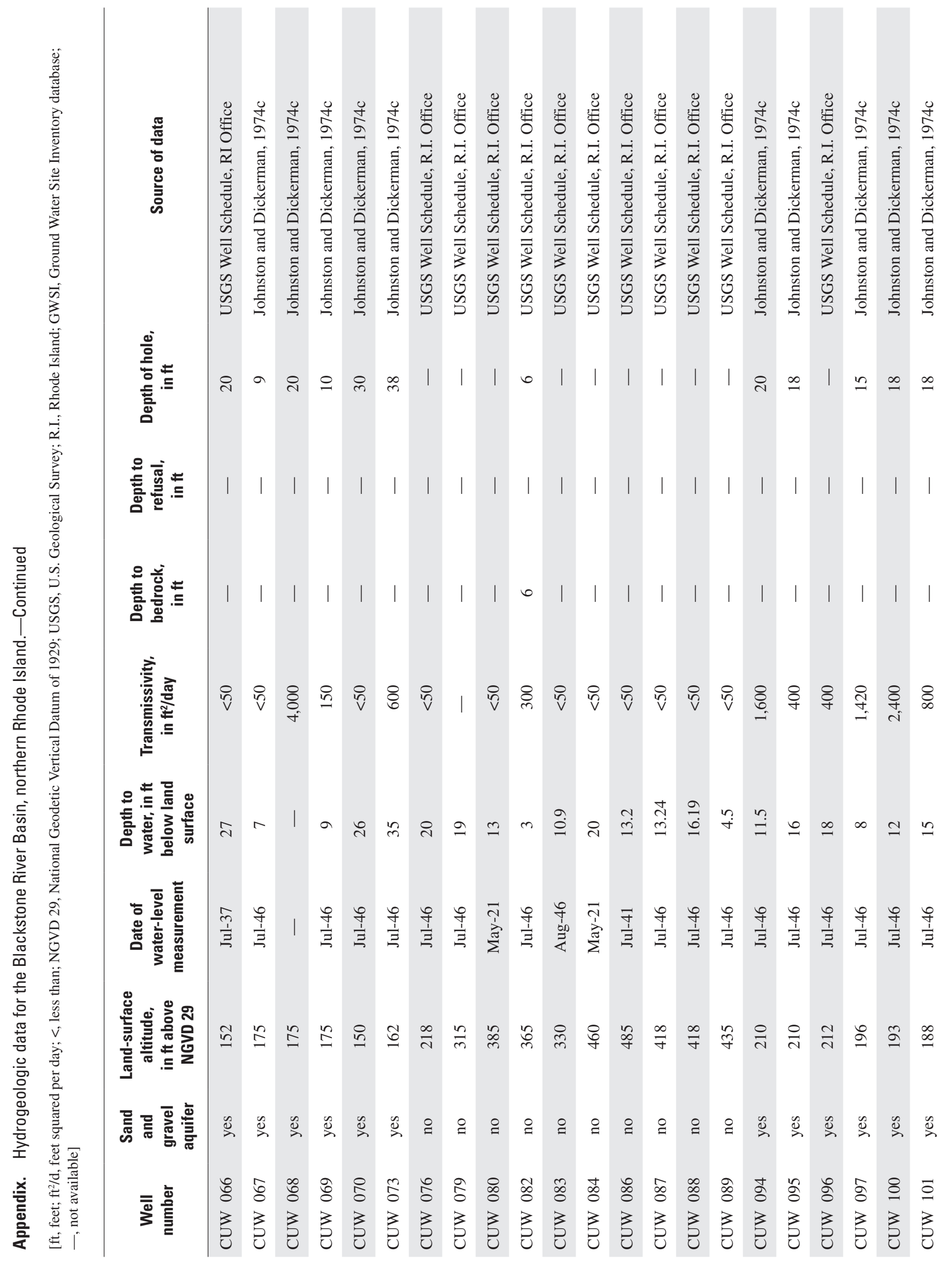




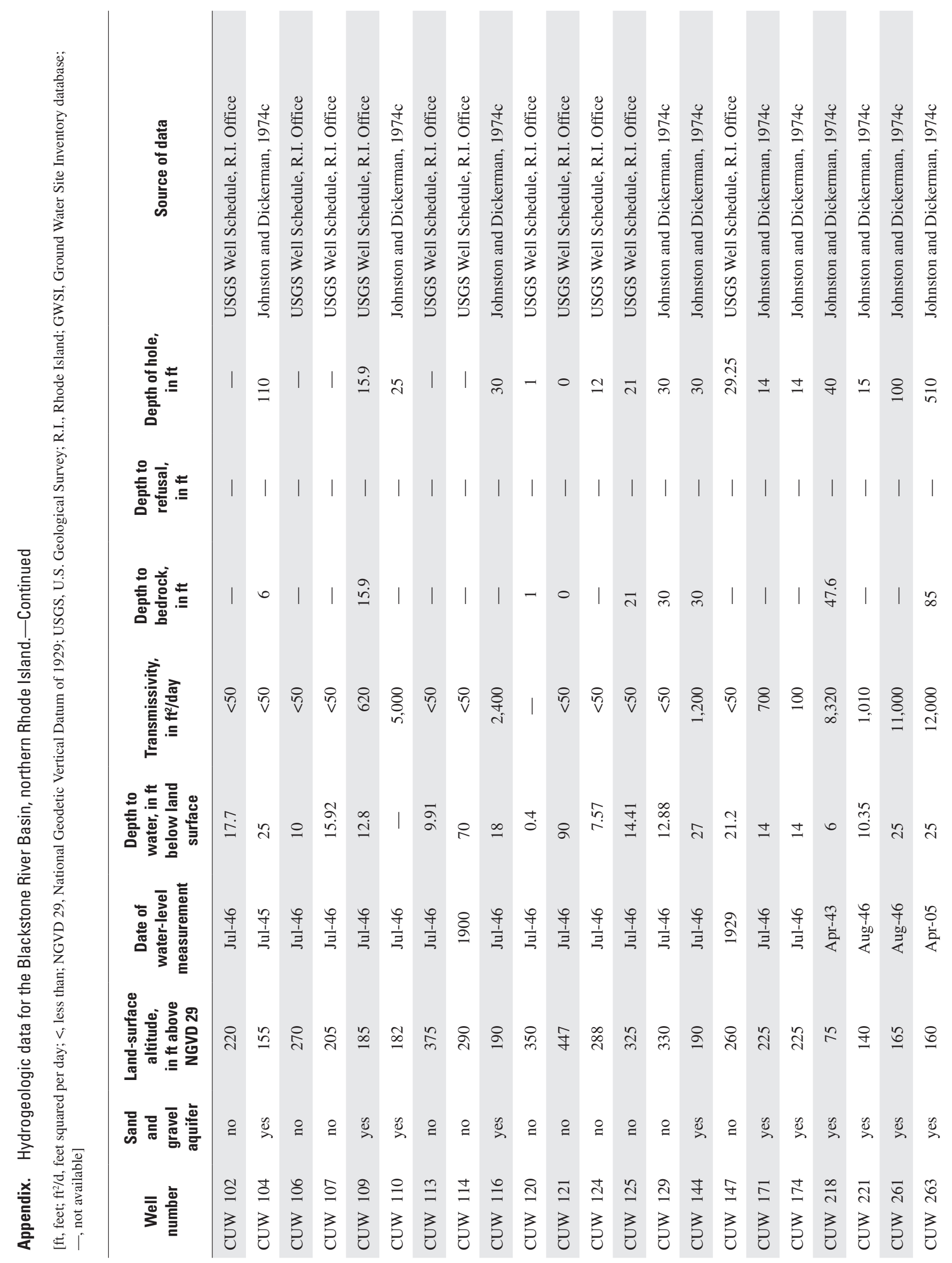




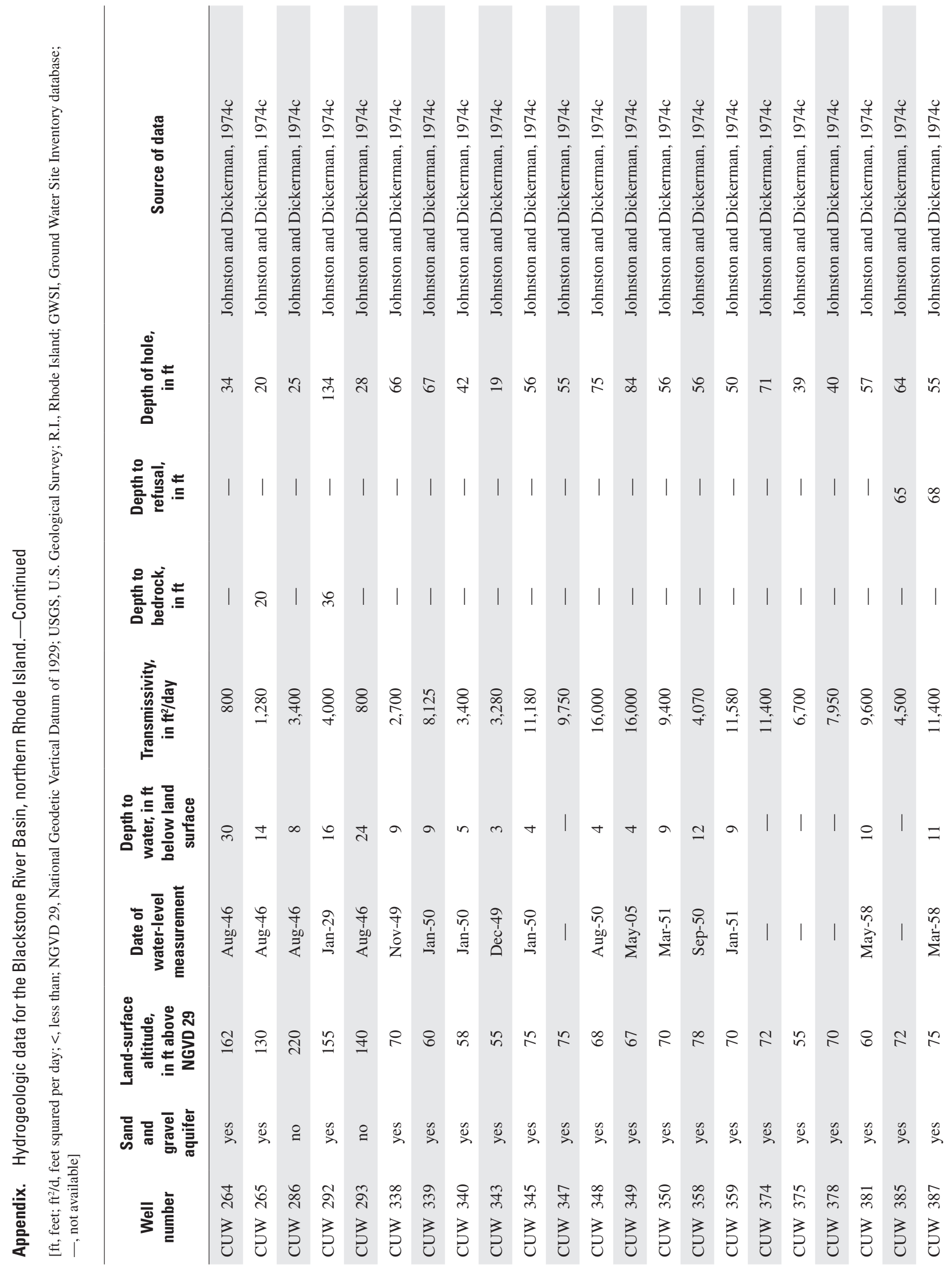




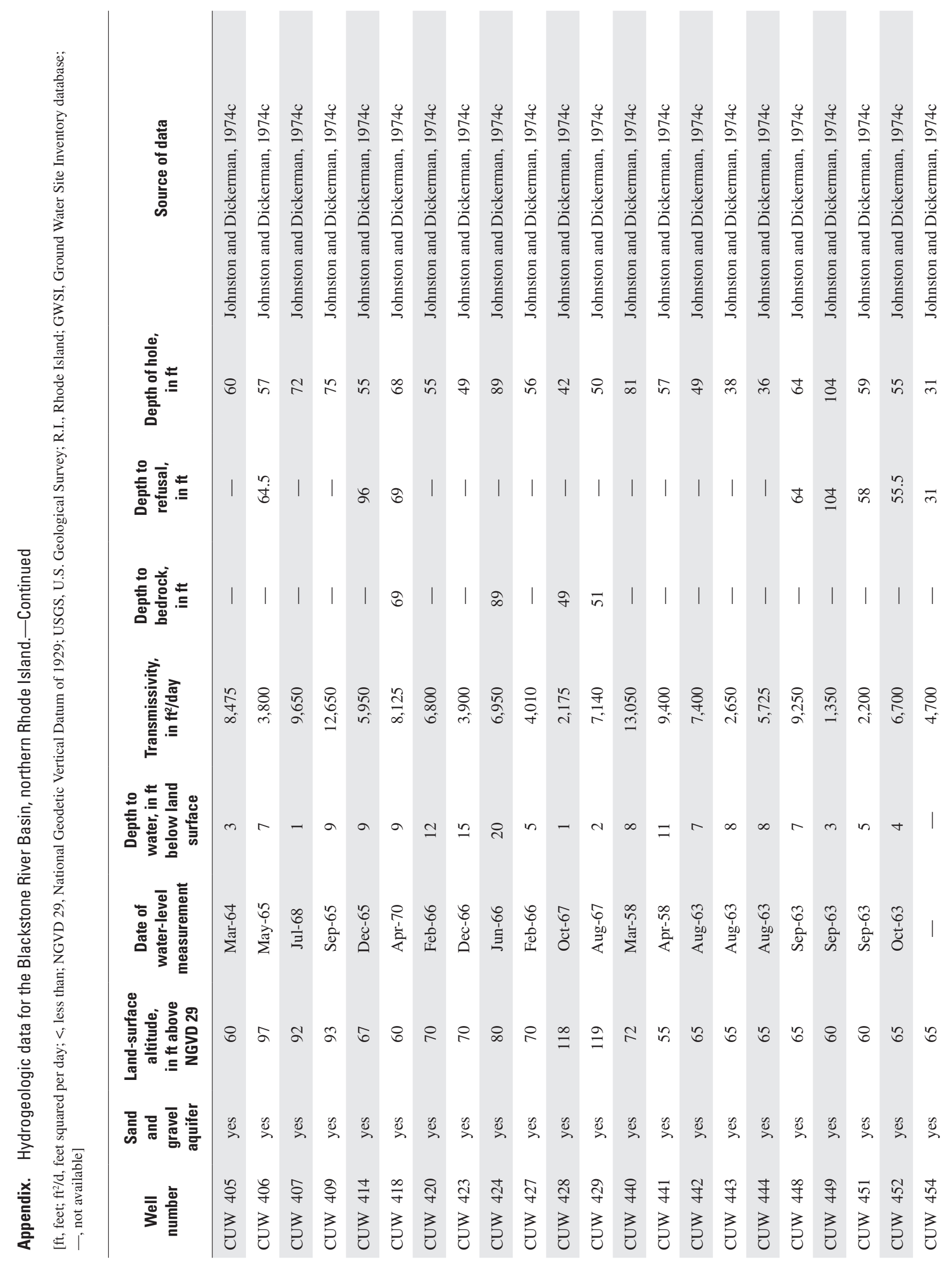




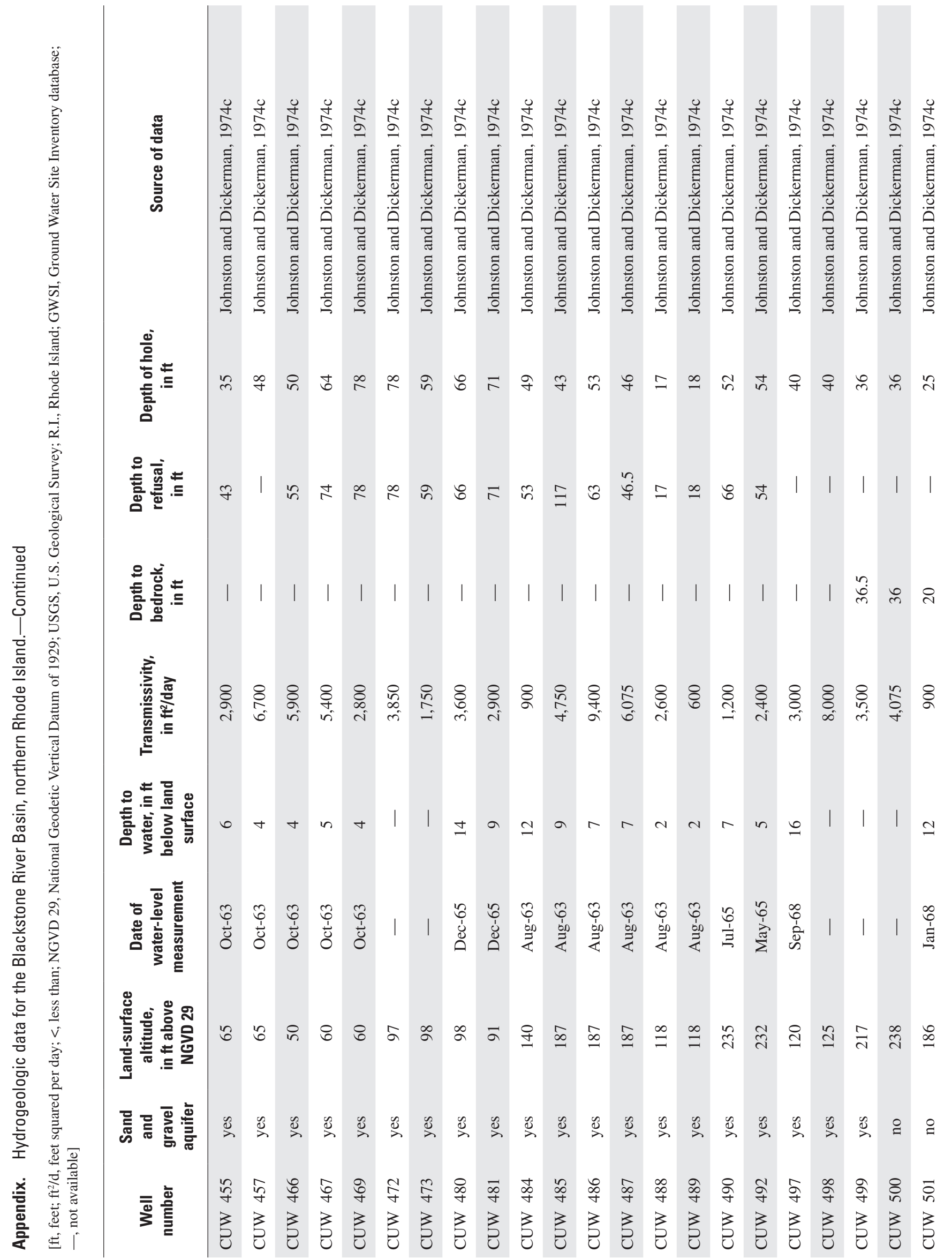




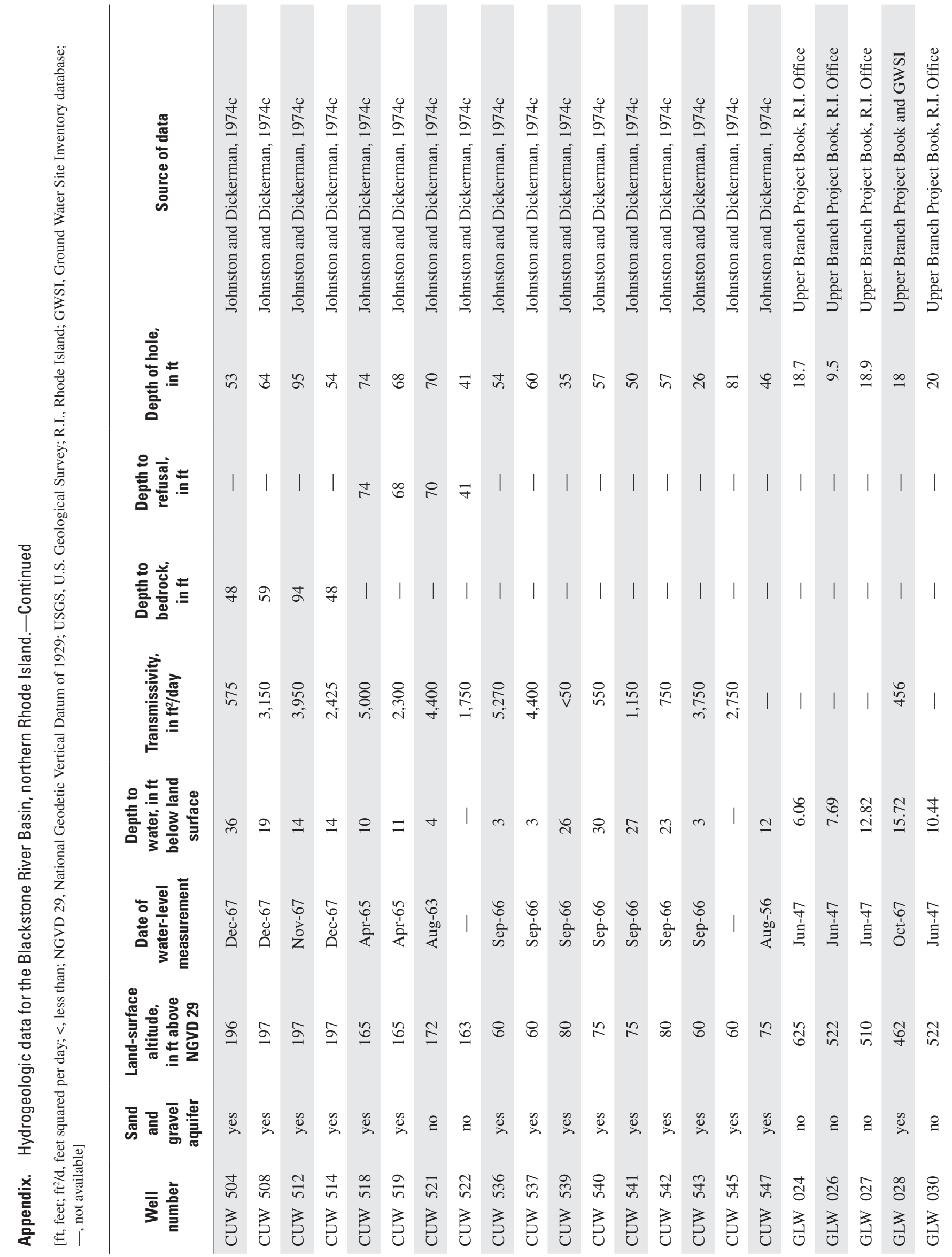




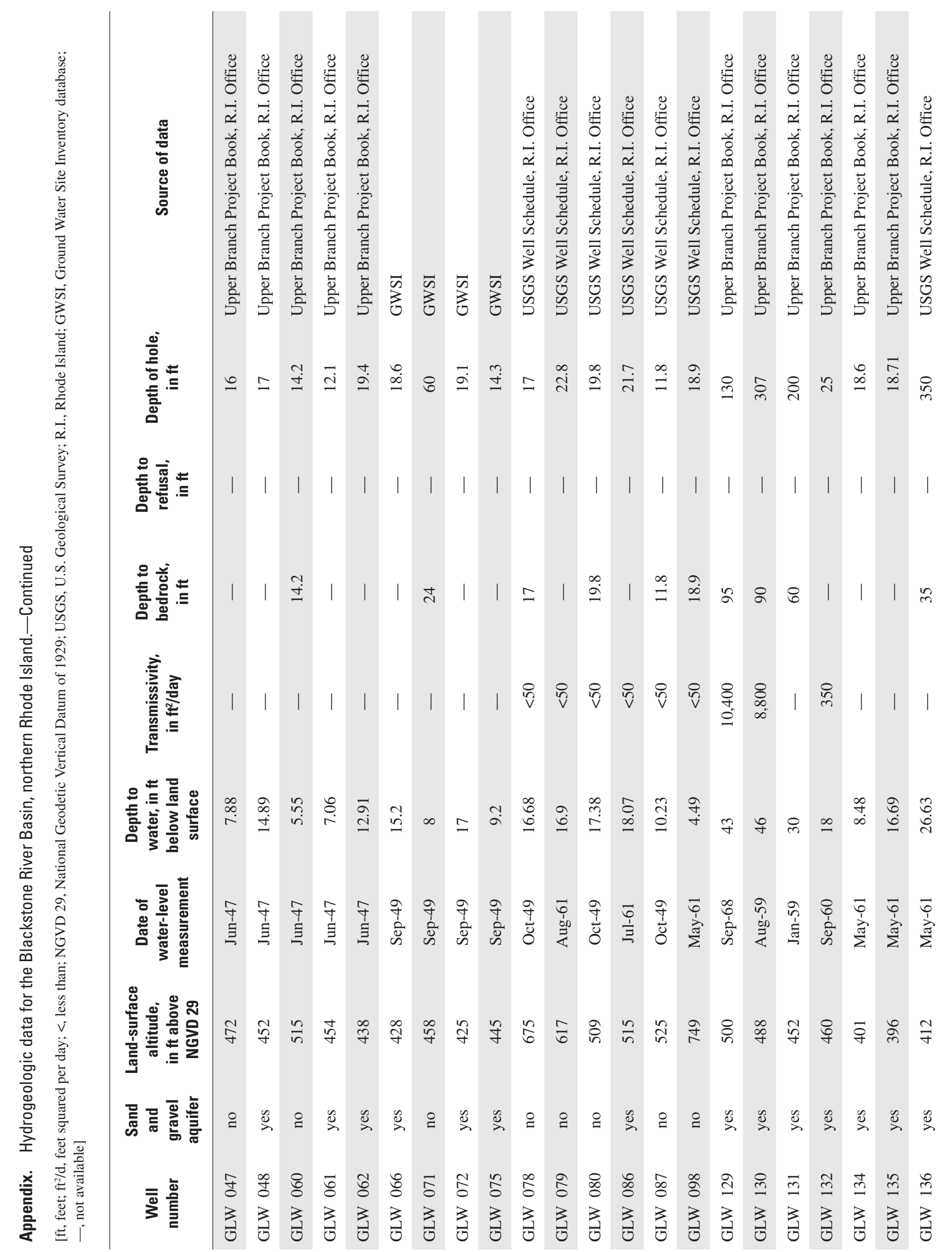




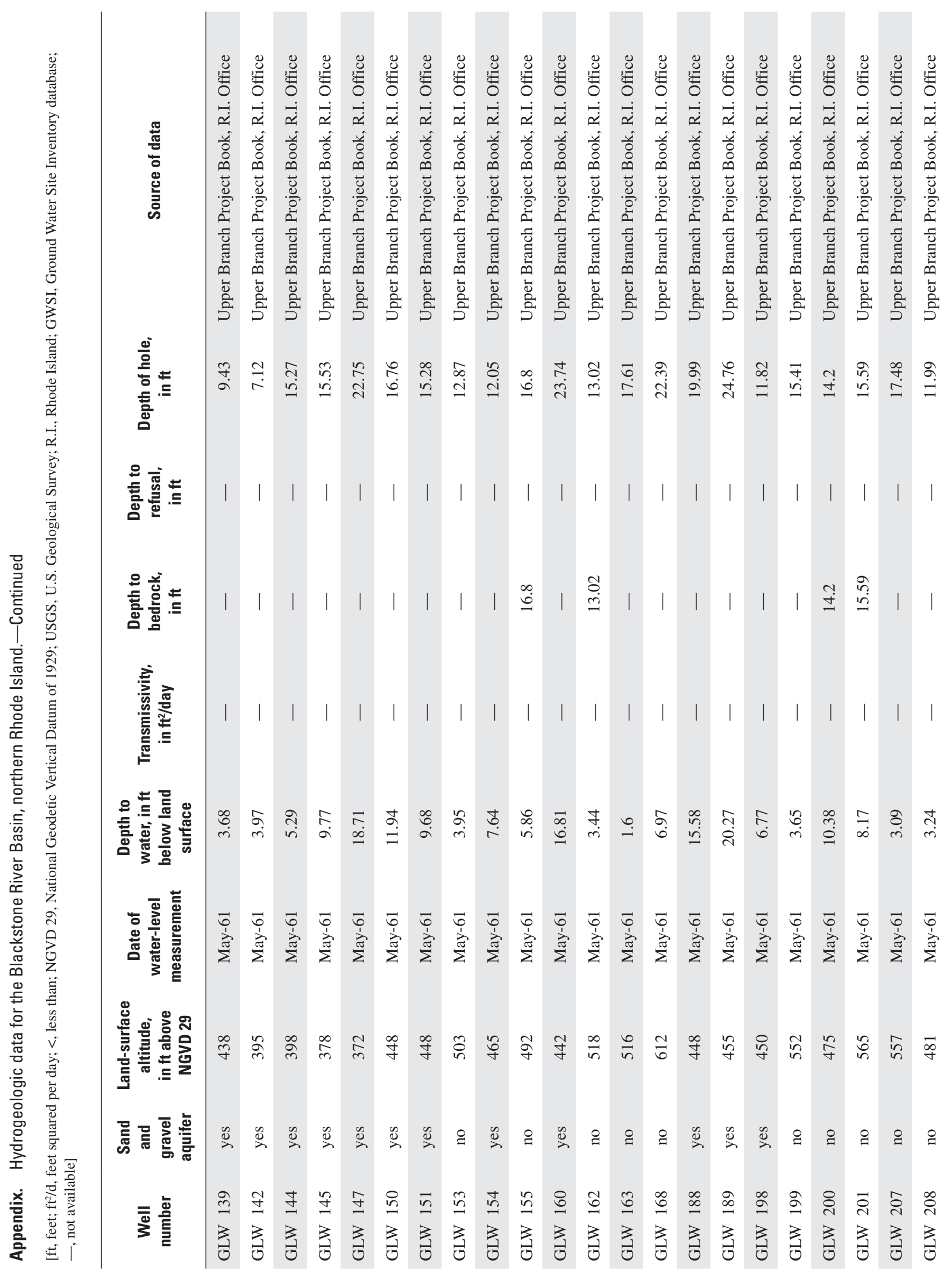




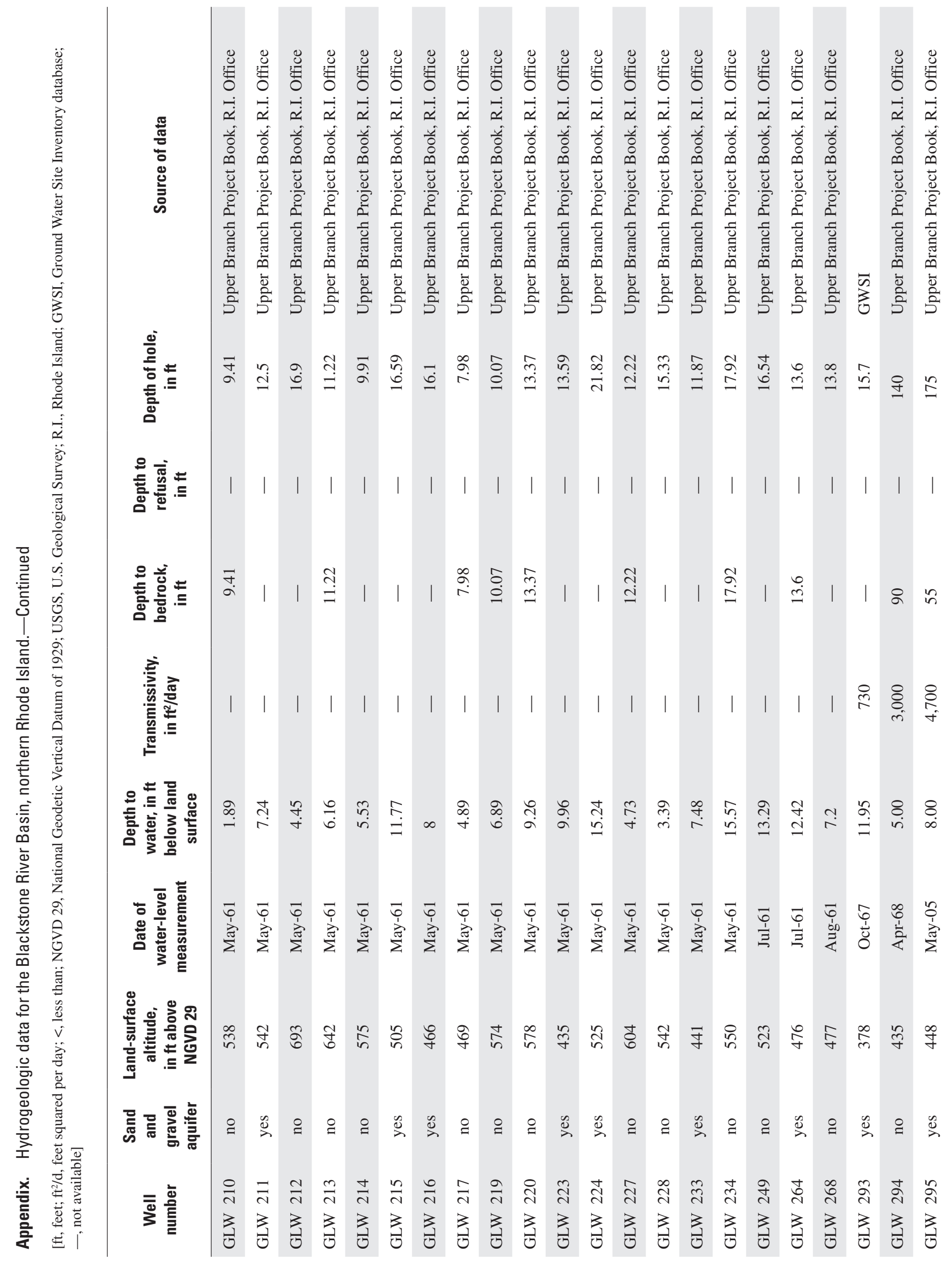




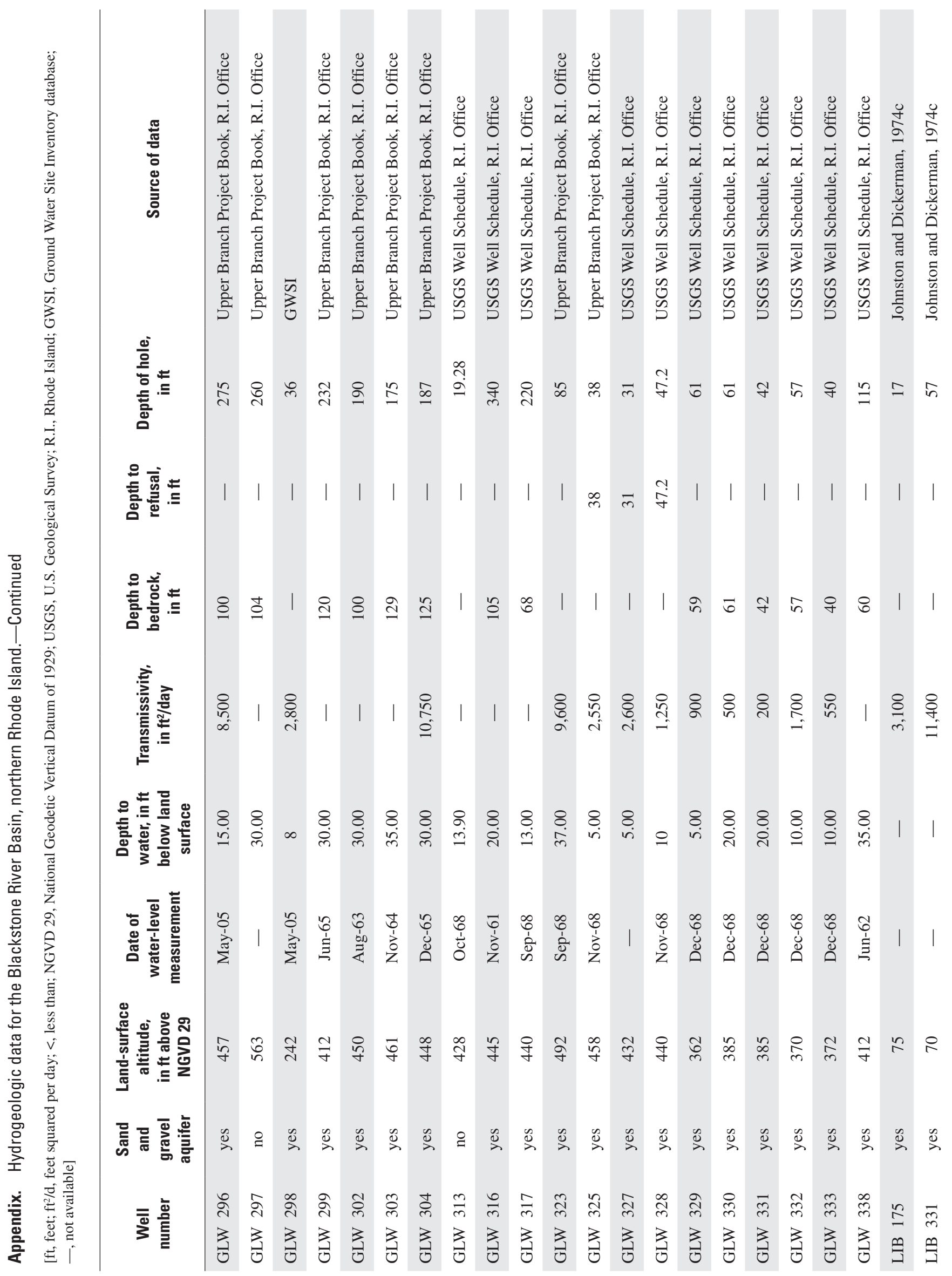




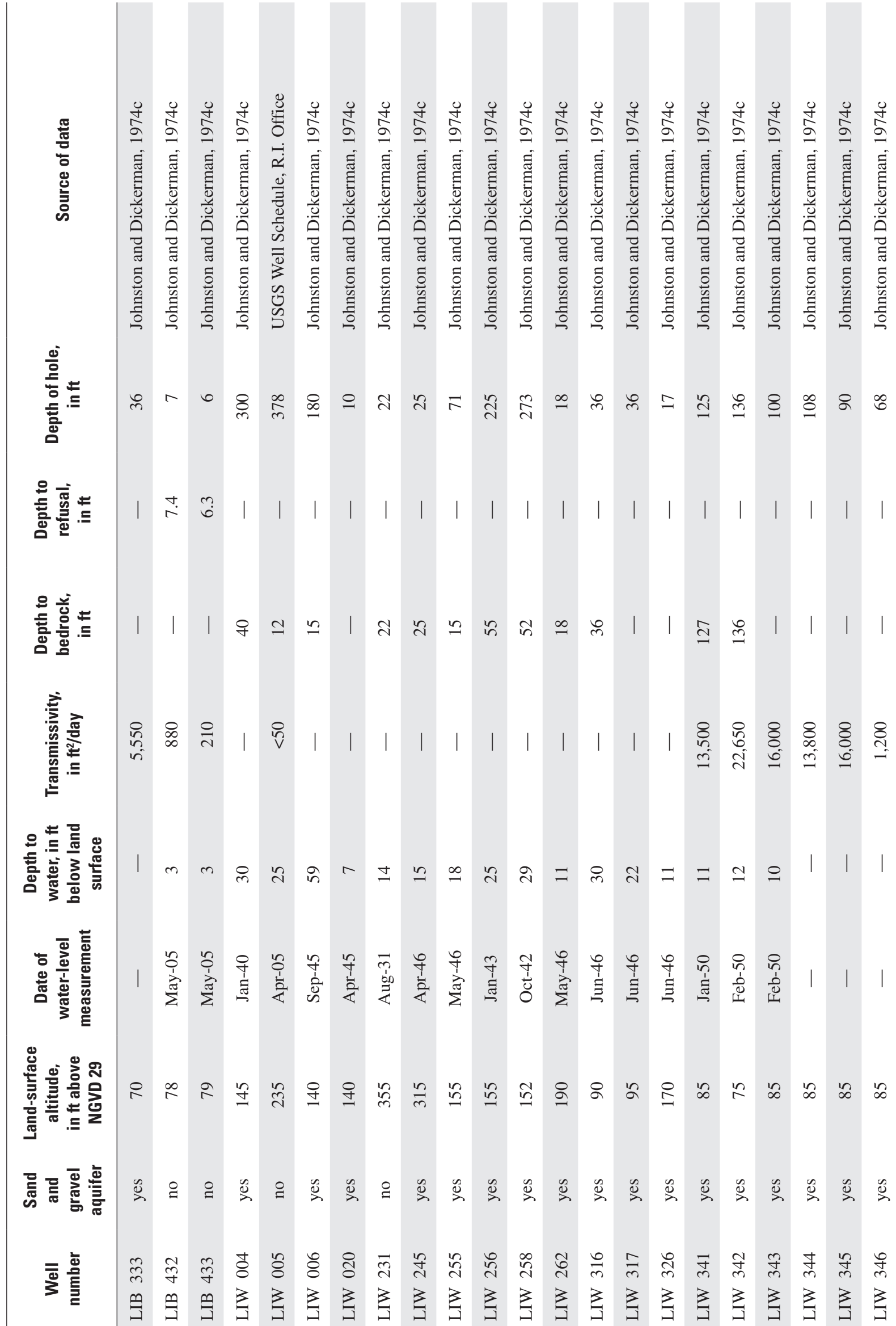




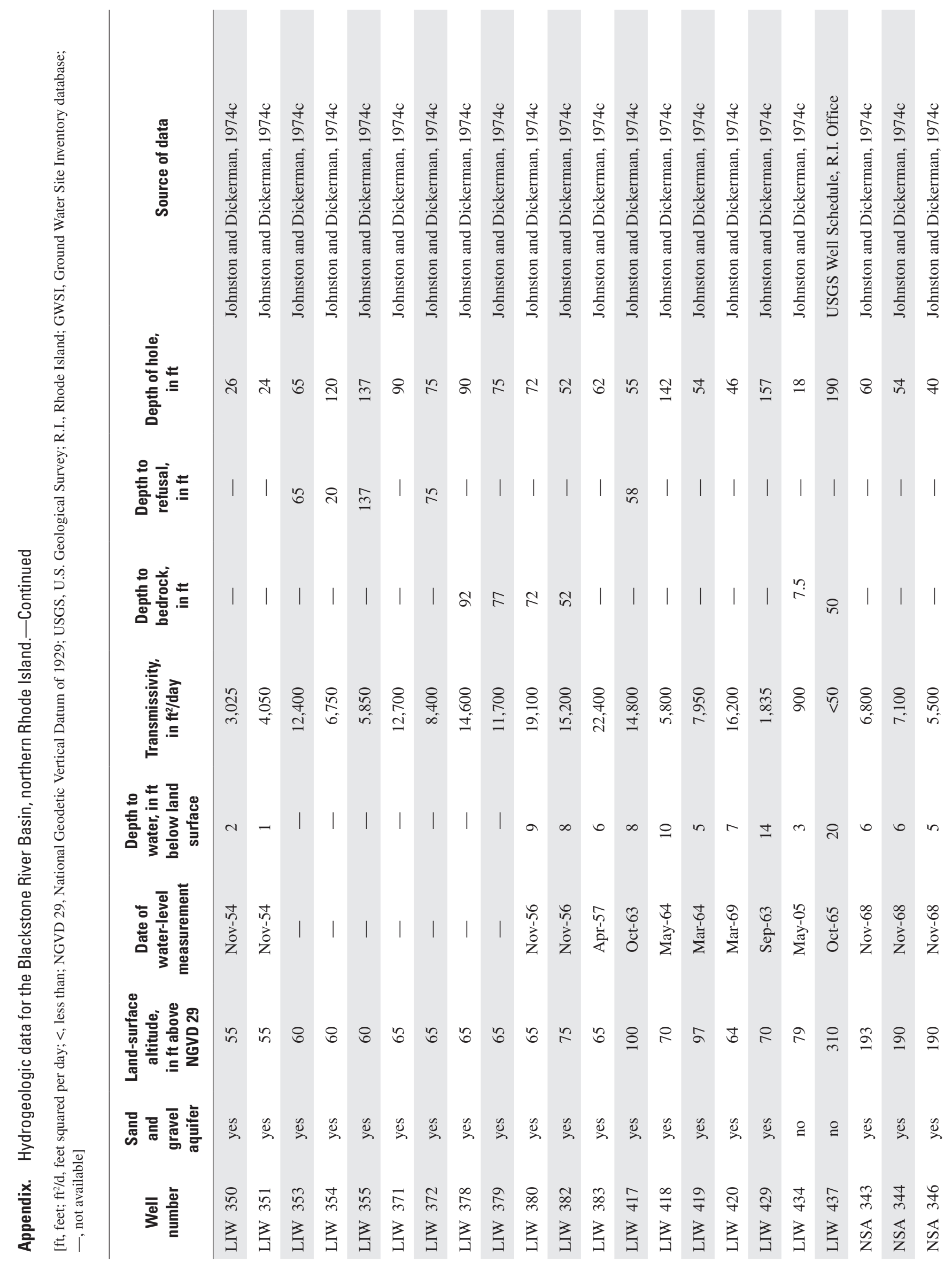




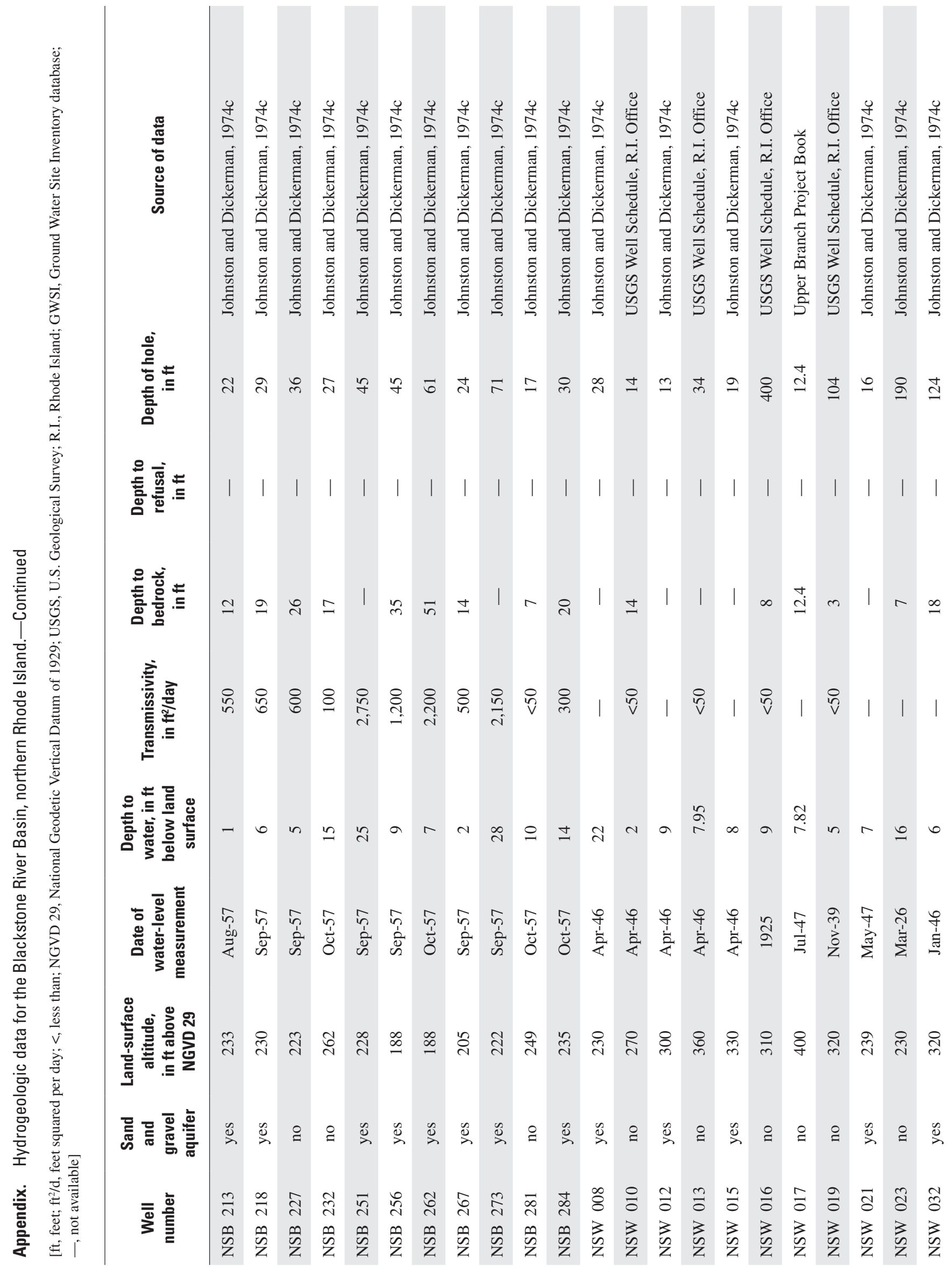




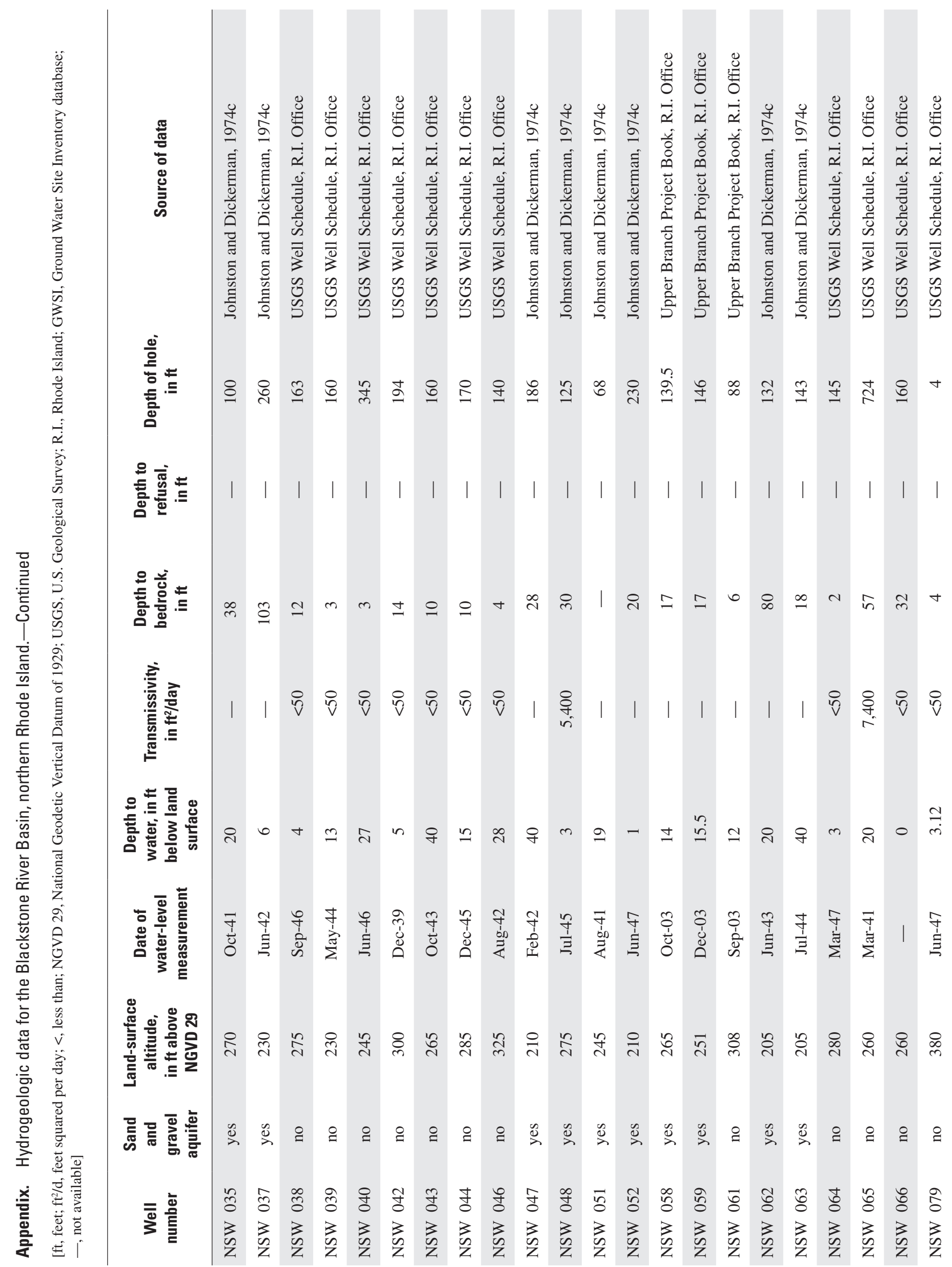




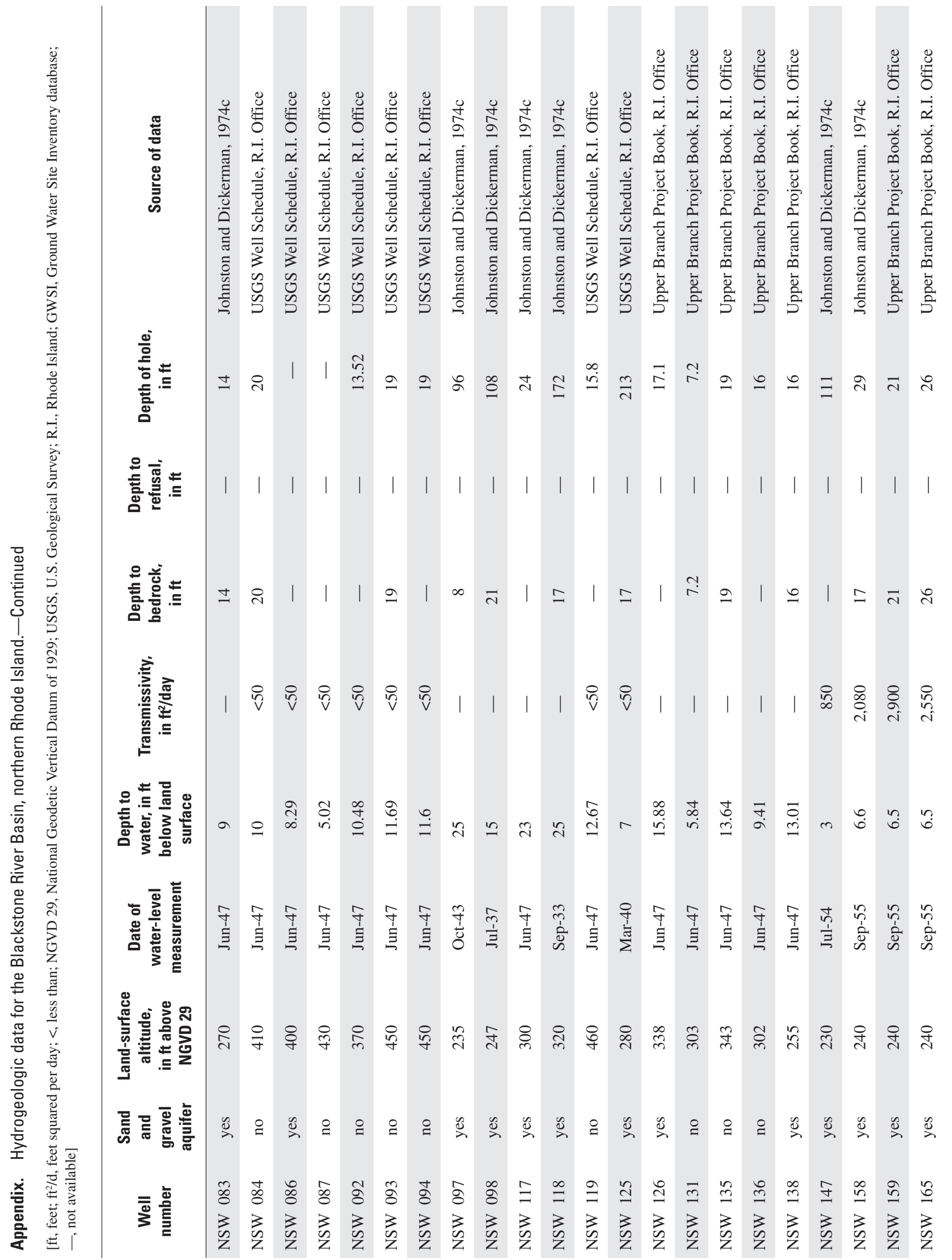




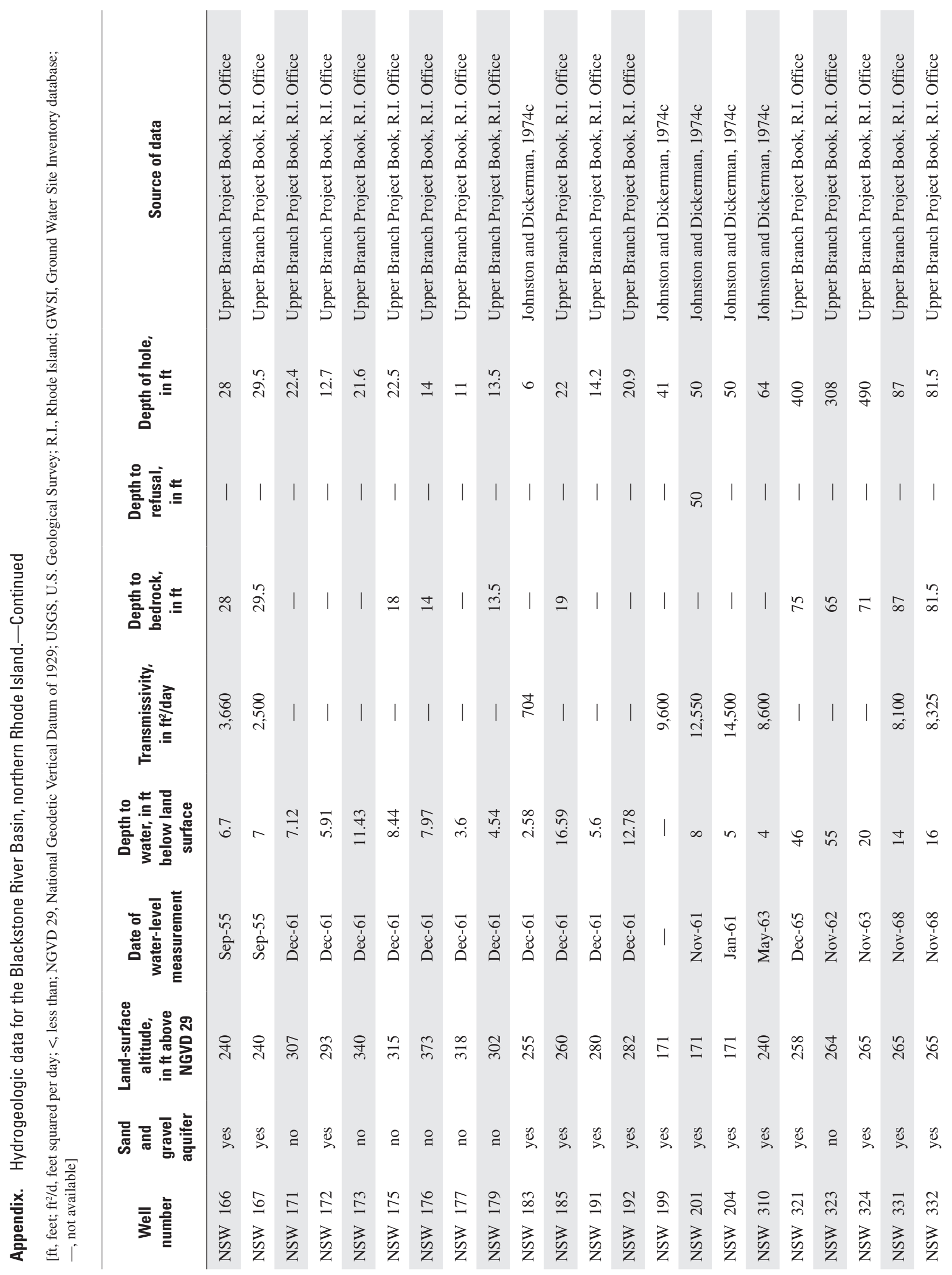




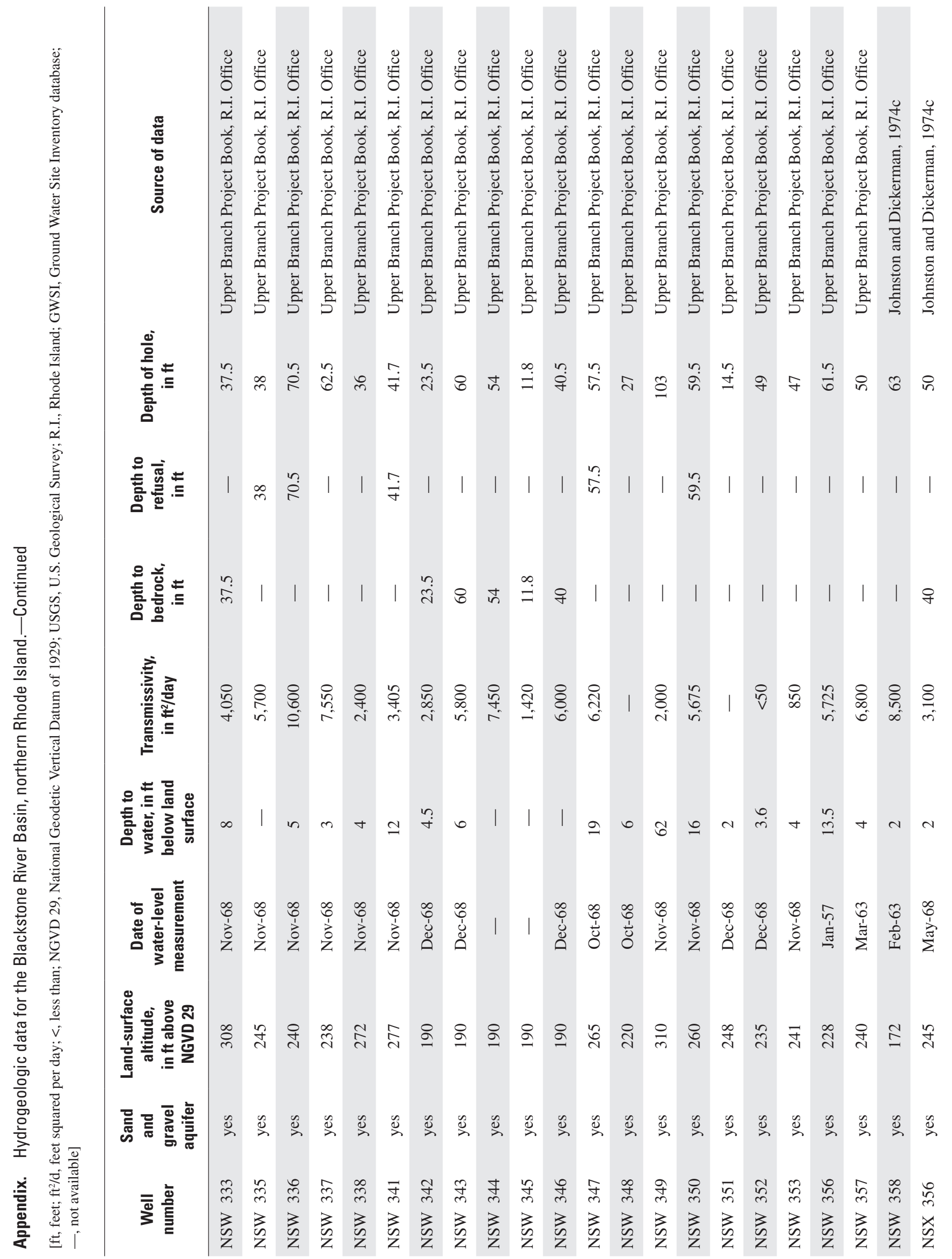




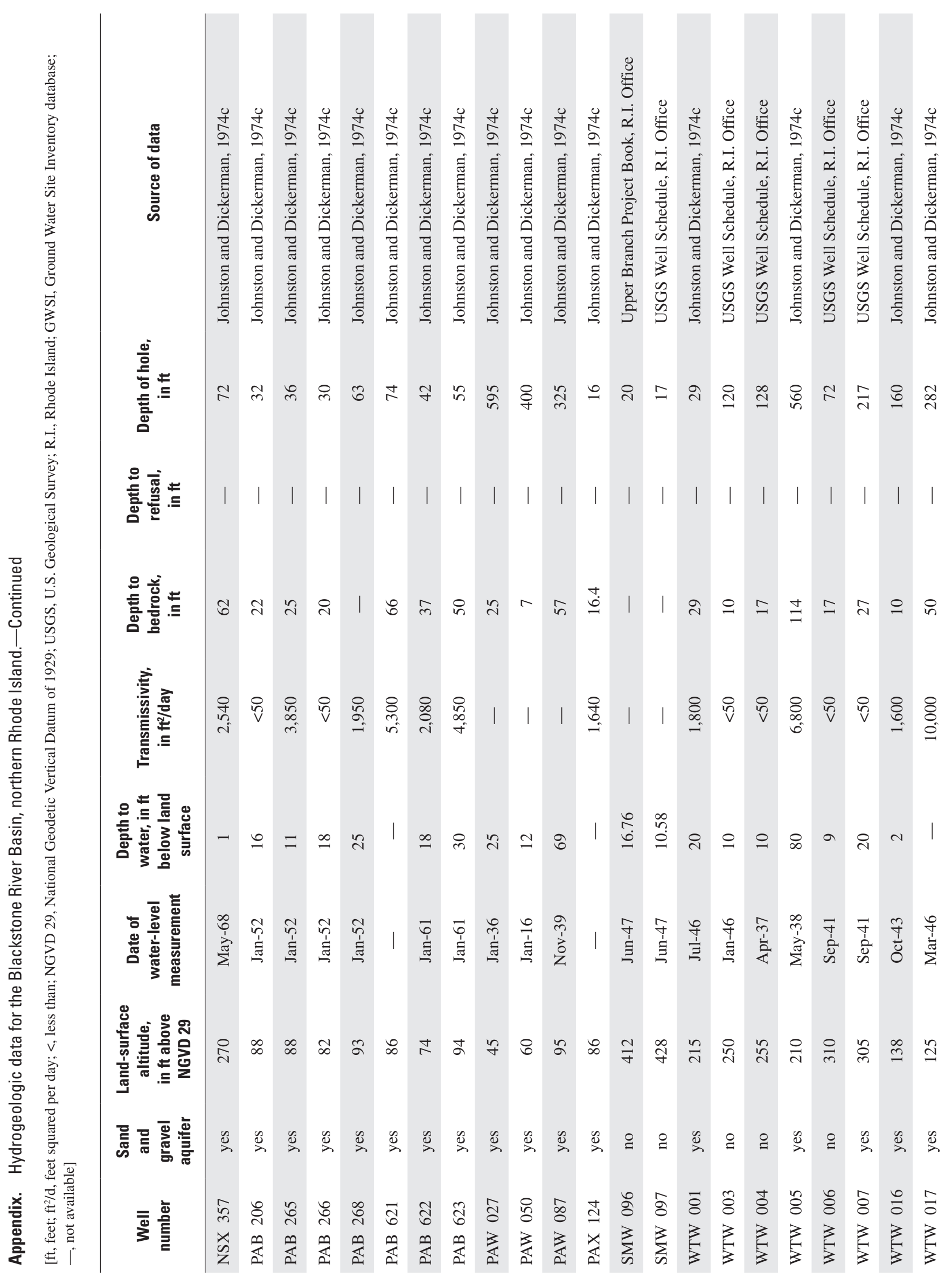




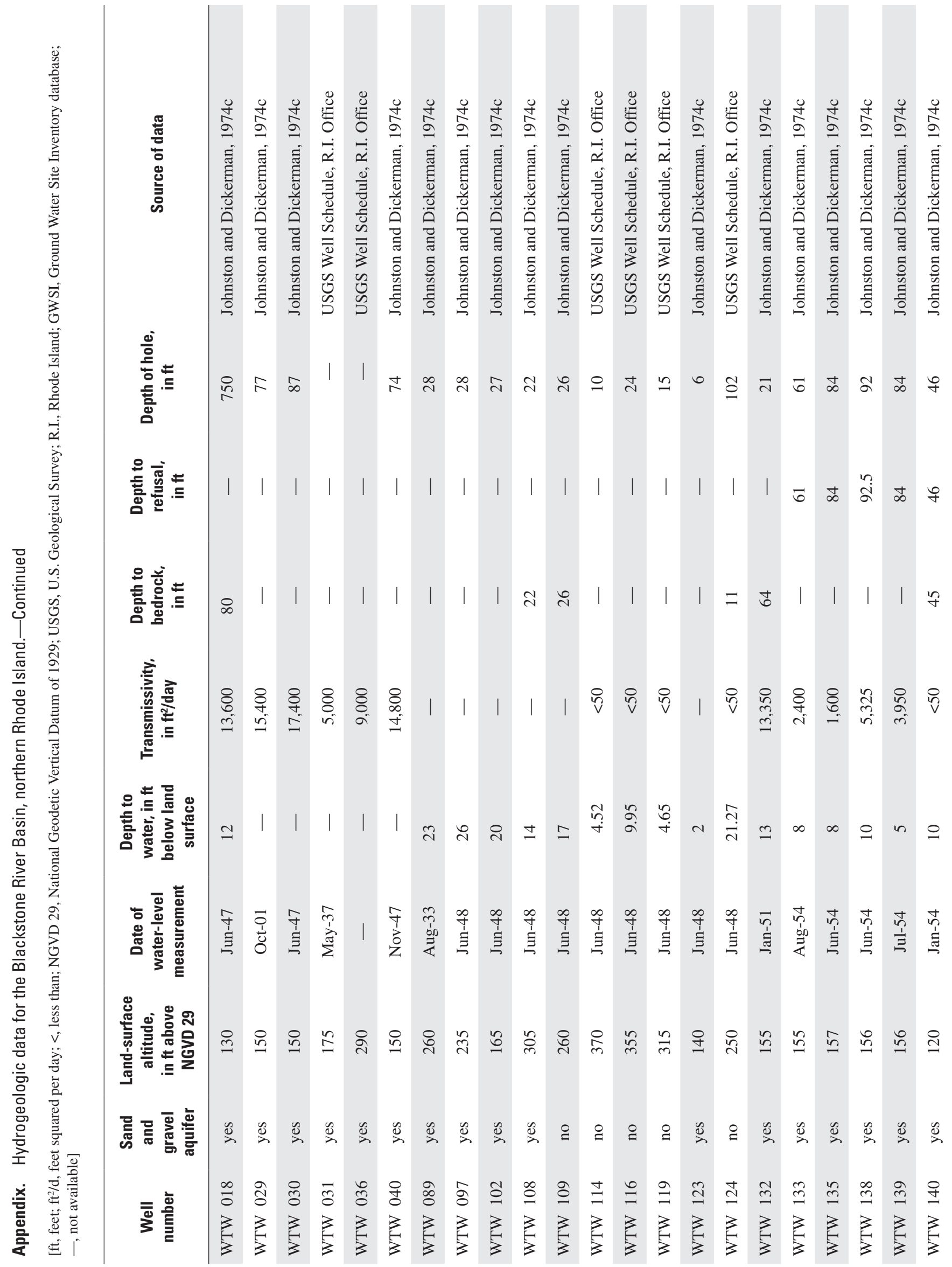




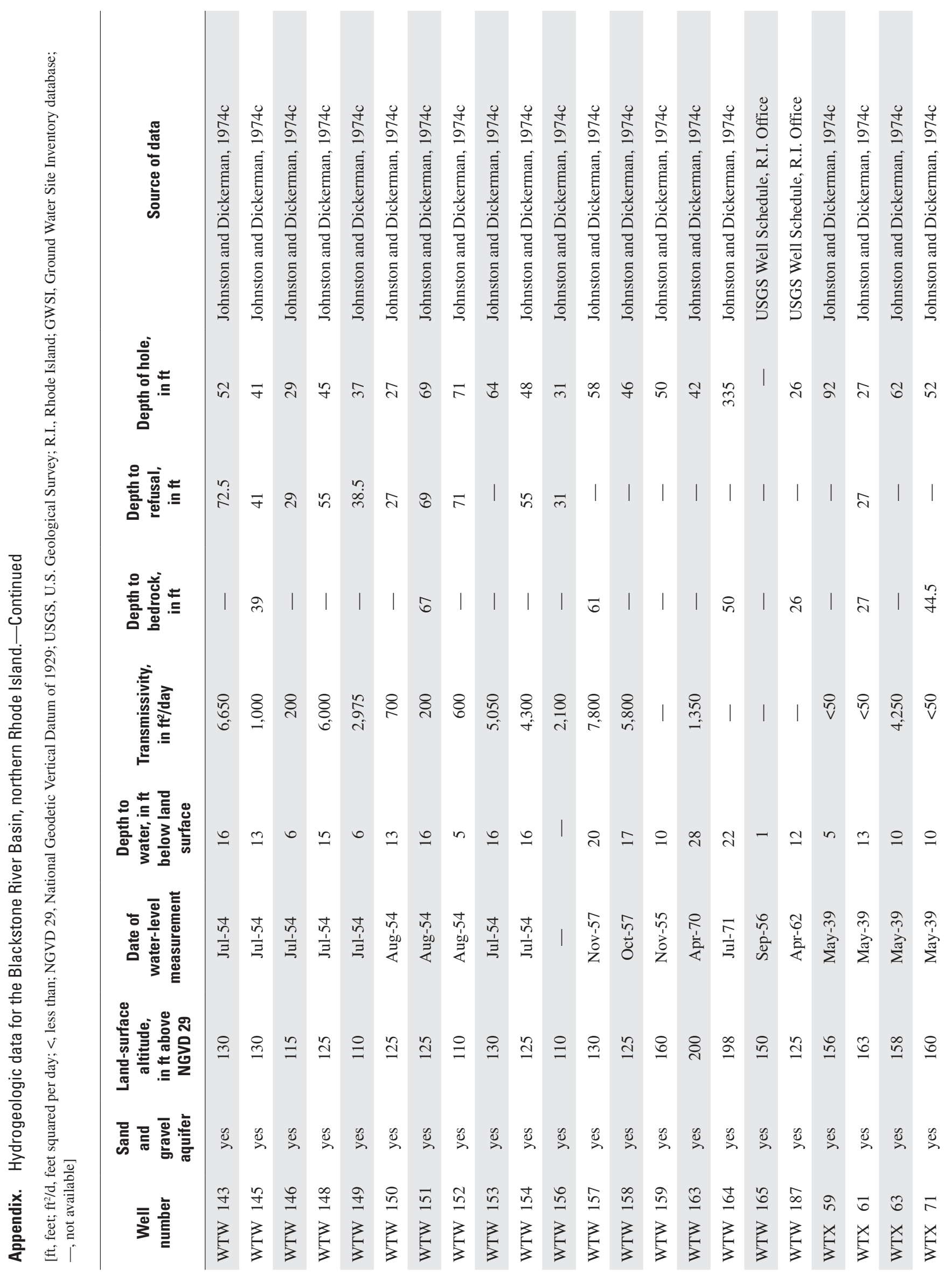




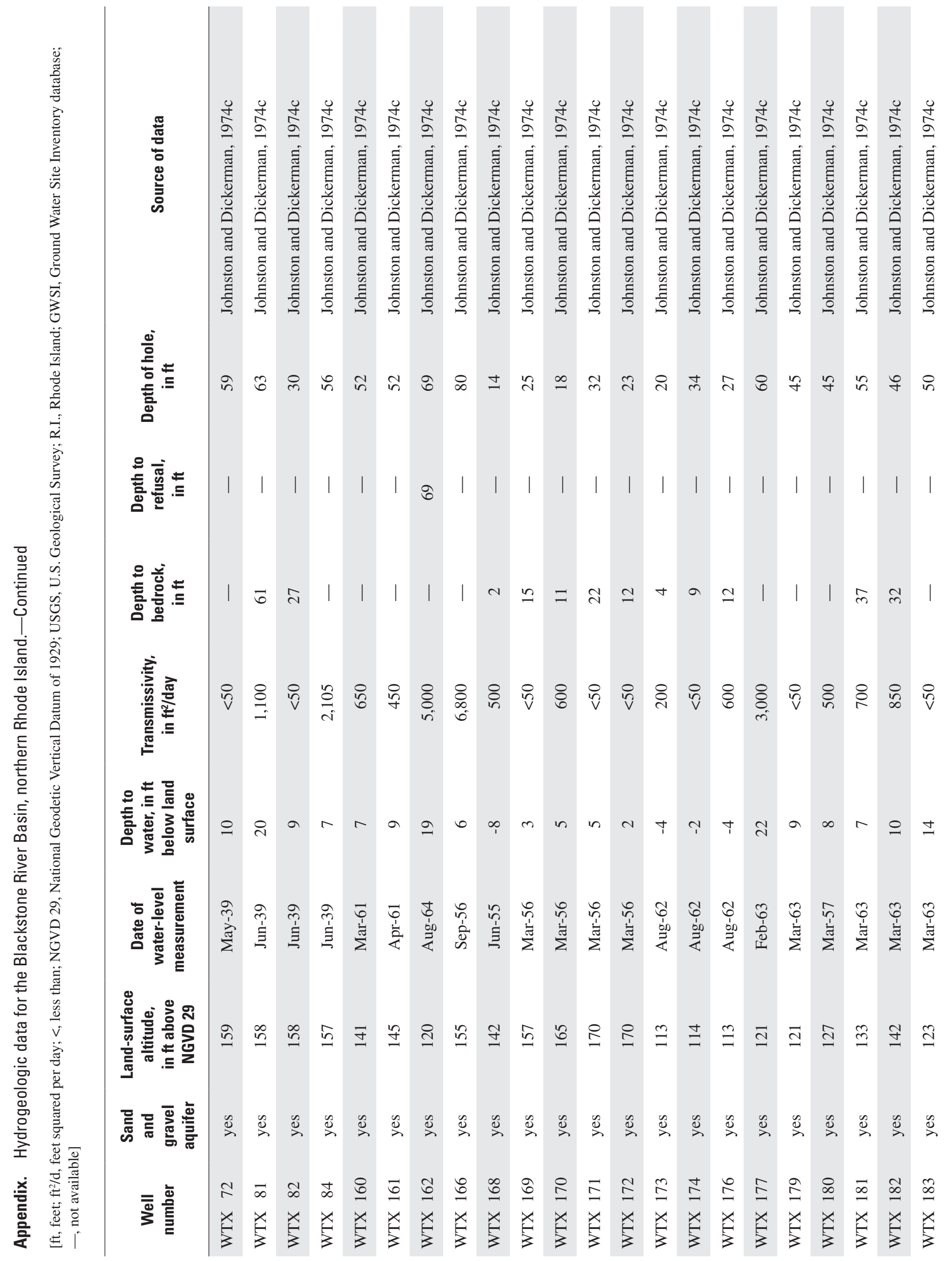




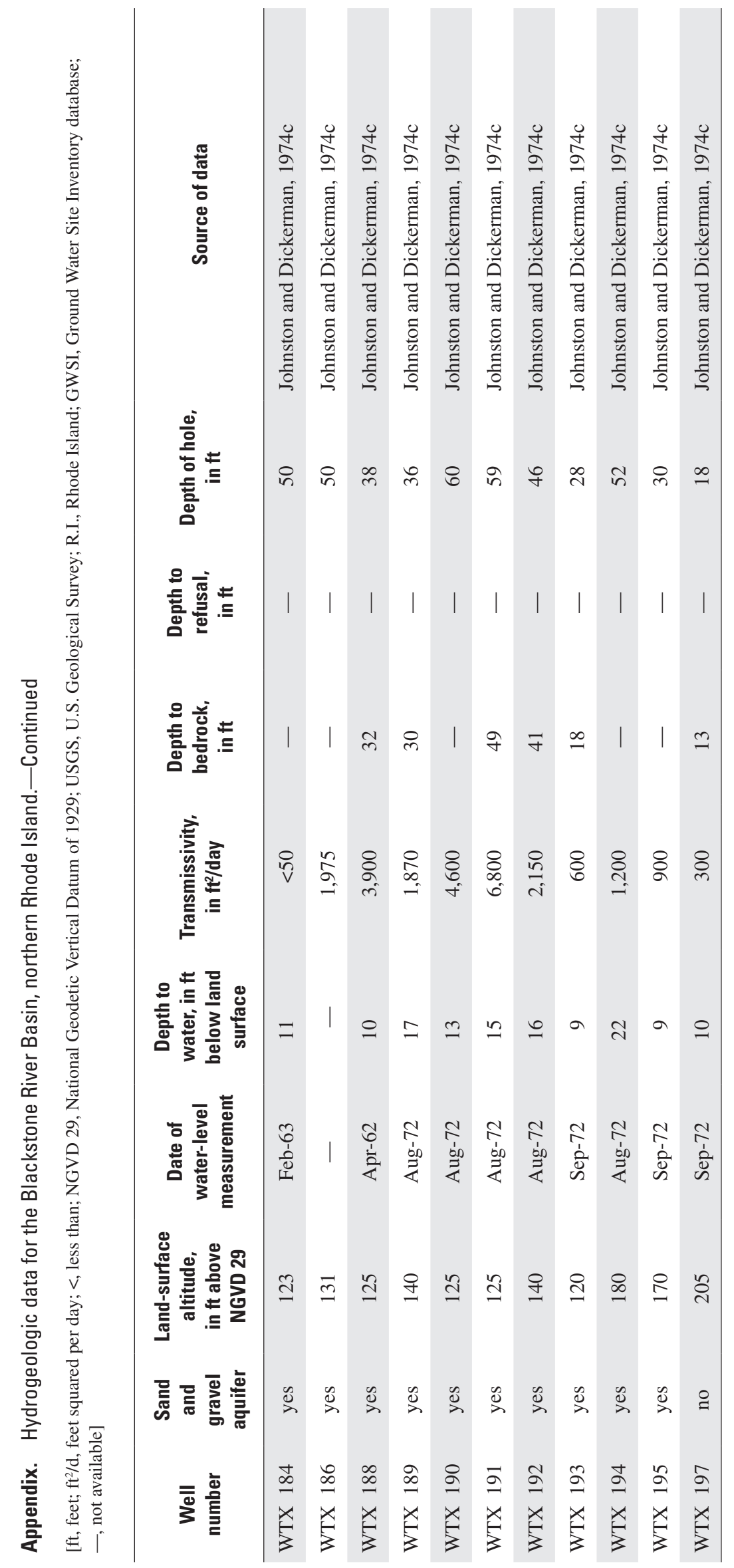




\title{
Long-Term Ground-Water Levels and Transmissivity in the Blackstone River Basin, Northern Rhode Island
}

\author{
By Jack R. Eggleston, Peter E. Church, and Jeffrey R. Barbaro
}

\section{Abstract}

Ground water provides about 7.7 million gallons per day, or 28 percent of total water use in the Rhode Island part of the Blackstone River Basin. Primary aquifers in the basin are stratified glacial deposits, composed mostly of sand and gravel along valley bottoms. The ground-water and surface-water system in the Blackstone River Basin is under stress due to population growth, out-of-basin water transfers, industrialization, and changing land-use patterns. Streamflow periodically drops below the Aquatic Base Flow standard, and groundwater withdrawals add to stress on aquatic habitat during low-flow periods.

Existing hydrogeologic data were reviewed to examine historical water-level trends and to generate contour maps of water-table altitudes and transmissivity of the sand and gravel aquifer in the Blackstone River Basin in Rhode Island. On the basis of data from four long-term observation wells, water levels appear to have risen slightly in the study area during the past 55 years. Analysis of available data indicates that increased rainfall during the same period is a likely contributor to the water-level rise. Spatial patterns of transmissivity are shown over larger areas and have been refined on the basis of more detailed data coverage as compared to previous mapping studies.

\section{Introduction}

The Blackstone River flows $46 \mathrm{mi}$ from its headwaters near Worcester, Massachusetts, the third largest city in New England, to the head of Narragansett Bay at Providence, Rhode Island, the second largest city in New England. About 126,600 people live in the Rhode Island part of the Blackstone River Basin (U.S. Census Bureau, 2000), and the population increased about 3.4 percent from 1990 to 2000. In addition to population growth, water transfers out of the basin, commercial and industrial growth, and changing land-use patterns have led to greater water use and stress on the water resources of the basin (Barlow, 2003). Ground water is an important source of water supply in the Rhode Island part of the Blackstone River Basin, providing about 7.7 Mgal/d, or
28 percent of total water use (Barlow, 2003). The U.S. Geological Survey (USGS), in cooperation with the Rhode Island Water Resources Board (RIWRB), is studying ground-water availability in the basin to help prepare for future population growth and increased water demand. This report focuses on the ground-water resources of the Blackstone River Basin in Rhode Island with a compilation and analysis of aquifer transmissivity and ground-water-level data. The results of this study can be used in developing water-resource management plans.

\section{Purpose and Scope}

This report presents an analysis of ground-water resources in the Rhode Island portion of the Blackstone River Basin. Spatial and temporal trends in ground-water levels, expressed as the altitude of the water table above the National Geodetic Vertical Datum (NGVD) of 1929, are analyzed and mapped. Available transmissivity data are used to compile a contour map that updates previous maps (Johnston and Dickerman, 1974a,b) and presents a broader regional view of transmissivity of the sand and gravel aquifer.

\section{Previous Investigations}

Water use and availability in the lower Blackstone River Basin, including the parts of the basin in both Rhode Island and Massachusetts, were documented by Barlow (2003). Ground water is withdrawn for private use and public watersupply use within the basin. An average of $2.12 \mathrm{Mgal} / \mathrm{d}$ of ground water was withdrawn for public supplies in the Rhode Island part of the Blackstone River Basin in 1995-1999 (Barlow, 2003, table 4). An additional 2.14 Mgal/d of ground water is estimated to supply private use, both domestic and commercial (Barlow, 2003, table 5, subtracting known surface water withdrawals). In 2003-2004, parts of the basin experienced low-flow conditions, with streamflow periodically dropping below the Aquatic Base Flow standard (ABF) (U.S. Fish and Wildlife Service, 1981). Withdrawals at wells have been shown to deplete streamflow, exacerbating effects on aquatic habitat during periods of low streamflow (Barlow, 2003).

Previous investigations have examined ground-water resources in part of the Blackstone River Basin in Rhode 
Island. Johnston and Dickerman examined ground-water availability and quality in the Branch River subbasin (1974a) and the eastern part of the Blackstone River Basin (1974b). Information from those reports was used in this study, in addition to information from the USGS Ground-Water Site Inventory (GWSI) database in the National Water Information System (http://waterdata.usgs.gov/nwis/), and unpublished well logs recorded by private drilling companies and by the USGS.

\section{Description of the Study Area}

The study area is the Blackstone River Basin in Rhode Island (fig. 1 and plate 1), which has a drainage area of 140 $\mathrm{mi}^{2}$; the entire Blackstone River Basin has a drainage area of $474 \mathrm{mi}^{2}$ in Rhode Island and Massachusetts. Nine towns are in the Rhode Island part of the basin: Burrillville, Central Falls, Cumberland, Glocester, Lincoln, North Smithfield, Pawtucket, Smithfield, and Woonsocket (fig. 1). Land-surface altitudes in the Rhode Island part of the basin range from sea level at the outlet of the basin to $804 \mathrm{ft}$ in the southwestern part of the basin. Topography is dominated by narrow river valleys bordered by relatively steep hills. The Blackstone River was once known as the "hardest working river in America," a reference to the many dams powering mills along the river.

The largest tributary to the Blackstone River in Rhode Island is the Branch River, which is formed by the confluence of the Clear River and the Chepachet River in the town of Burrillville. The Branch River has a drainage area of $91 \mathrm{mi}^{2}$, or 65 percent of the Blackstone River Basin in Rhode Island. The Branch River joins the Blackstone River in the northeastern corner of North Smithfield, about $1 \mathrm{mi}$ upstream from Woonsocket. The only other major tributary to the Blackstone River with drainage area in Rhode Island is Abbot Run, which joins the Blackstone River at the border between Cumberland and Central Falls, less than 2 mi upstream from the Seekonk River. Abbott Run has a drainage area of $28 \mathrm{mi}^{2}$, or 20 percent of the Blackstone River Basin in Rhode Island.

\section{Land Use and Water Use}

Land in the basin is mostly forested (53 percent), with the remainder composed of residential areas (19 percent), water/wetlands (14 percent), urban/industrial areas ( 9 percent), and agricultural lands (5 percent). Geospatial data describing land use, surface geology, and surface-water occurrence were compiled for this study.

All of the towns in the basin are at least partly supplied with water from public water-supply authorities. Water is withdrawn from a few surface-water reservoirs and from ground-water wells throughout the basin to meet water demands. Although the sand and gravel aquifer is the source of most ground-water supplies, till and bedrock deposits do supply ground water to numerous private wells. Barlow (2003) reported that surface-water and ground-water withdrawals in the Rhode Island part of the Blackstone River Basin averaged 27.7 Mgal/d during 1995-1999, with ground-water withdrawals constituting $7.7 \mathrm{Mgal} / \mathrm{d}$ or 28 percent of the total.

\section{Hydrogeology}

Unconsolidated stratified glacial deposits underlie 30 percent of the Blackstone River Basin in Rhode Island; the remainder of the basin has exposed bedrock ( 2 percent), till (64 percent), or open water (4 percent) at the land surface. The irregularly shaped valleys are filled with stratified glacial deposits ranging in grain size from clay to gravel. Coarsegrained sand and gravel form the primary aquifer deposits, which are thin, discontinuous, and unconfined (plate 1).

Due to high aquifer permeability and short ground-water travel distances to streams, typically less than 3,000 ft, water withdrawals from the sand and gravel aquifer can cause relatively rapid flow reductions in nearby streams. Although the sand and gravel aquifer is the principal source of ground-water supplies, small withdrawals also are made from wells in till and bedrock areas, generally from private wells supplying a single home or business.

The RIWRB has published a map of ground-water reservoirs, which are the parts of the state's sand and gravel aquifers that have the greatest potential for supplying ground water, a saturated thickness of $40 \mathrm{ft}$ or greater, and a transmissivity of $4,000 \mathrm{ft}^{2} / \mathrm{d}$ or greater (Rhode Island Statewide Planning Program,1979; Rhode Island Department of Environmental Management, 1991).

\section{Precipitation}

Precipitation in the basin increased from 1949 to 2003 , but averaged $46 \mathrm{in} / \mathrm{yr}$, based on records at the National Oceanographic and Atmospheric Administration (NOAA) climatological station 379423 in Woonsocket, Rhode Island (fig. 1). Evapotranspiration (ET) can be estimated from streamflow records for the Branch River streamflow-gaging station at Forestdale, R.I. (USGS station 01111500), which represents 91 $\mathrm{mi}^{2}$, the largest unregulated part of the Blackstone River Basin in Rhode Island. Streamflow at the Forestdale, R.I. station averages $25.9 \mathrm{in} / \mathrm{yr}$ based on mean annual streamflow from 1941 through 2003. If the difference between precipitation and streamflow is assumed to be lost to ET, then ET equals 20.1 in/yr, or 44 percent of precipitation, for the Branch River Basin. Recharge to the aquifer in the Branch River Basin is $19.0 \mathrm{in} / \mathrm{yr}$, or 41 percent of precipitation, based on a hydrograph separation estimate of base flow at the Forestdale station from 1941 to 2003. 


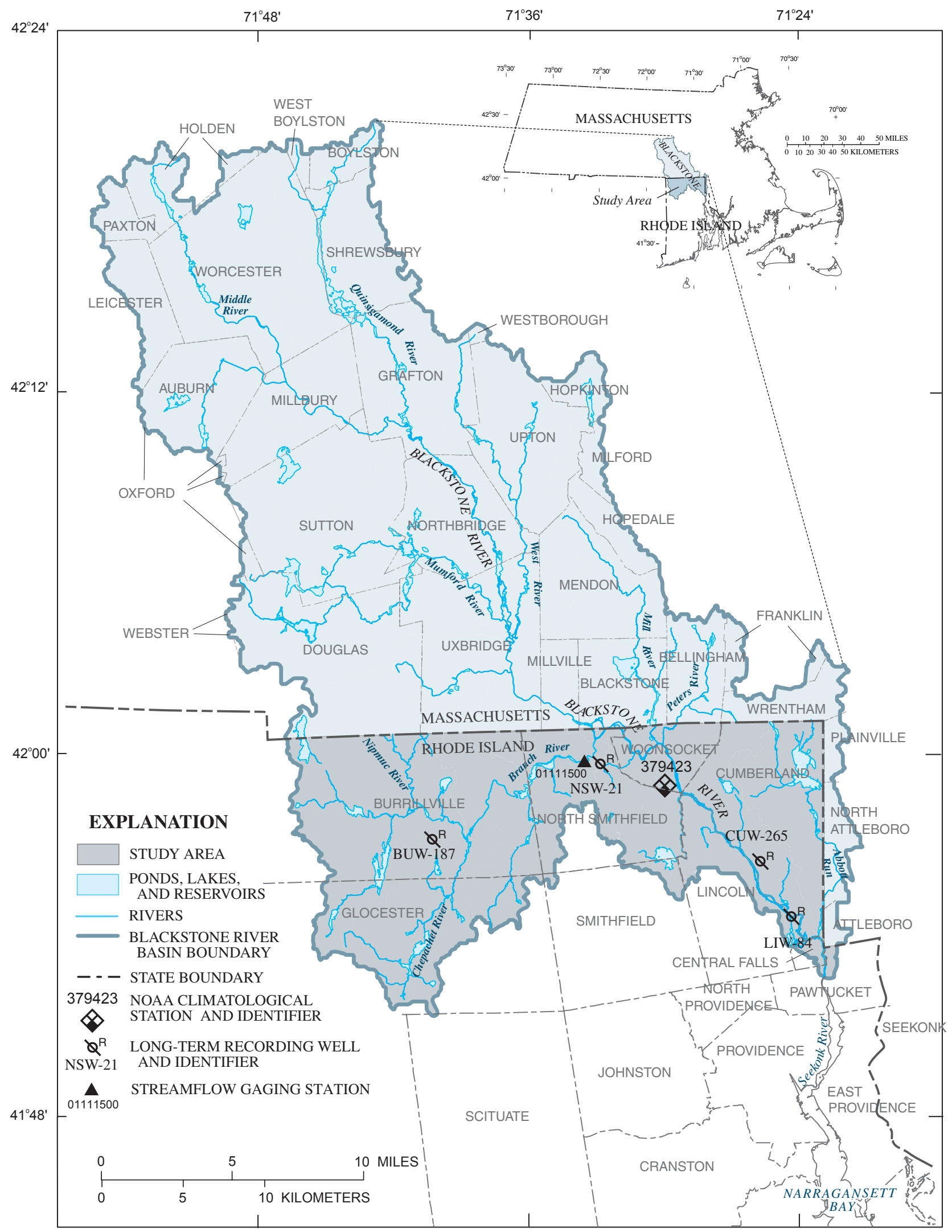

Base from the National Resource Conservation Service

12-digit HUC base map, 1:24,000, 2001

Projection: Rhode Island State Plane

1983 North American datum

Figure 1. Blackstone River Basin and study area, northern Rhode Island. 


\section{Data Compilation}

For this study, hydrogeologic data were compiled from previously published studies. A comprehensive literature search was conducted to find hydraulic conductivity, aquifer thickness, and ground-water-level data. The data were then formatted and organized in a database for ease of access and analysis. The Appendix contains the hydrogeologic data on which the mapping and analysis were based.

\section{Ground-Water Levels}

A contour map of the altitude of the water table in the sand and gravel aquifer was constructed on the basis of 726 water-level measurements made in wells (plate 1). The water levels were measured from 1900 to 2003 at various times of the year. In cases where water levels were measured more than once at a single well, the measurements were averaged.

Because the water table is close to the land surface throughout the Blackstone River Basin and the aquifer is unconfined, it is assumed that ground water is hydraulically connected to surface water. Therefore, altitudes of surfacewater bodies such as streams, ponds, and reservoirs were used to map the altitude of the water table. The altitudes of surface-water bodies and stream reaches were estimated from geospatial data obtained from the Rhode Island Geographic Information System (RIGIS). Altitudes at 15,815 surfacewater points were obtained in this manner and used to contour the water-table altitude.

Long-term, detailed, water-level records were compiled for four observation wells (RI-LIW-84, RI-CUW-265, RINSW-21, and RI-BUW-187) screened in the stratified glacial deposits (fig. 1). Periodic water-level measurements from the 1940s through 2003, obtained from the GWSI database, were used to develop time series of water-table altitudes for these wells (fig. 2).

\section{Transmissivity}

Transmissivity $(\mathrm{T})$ is a variable that expresses the ability of an aquifer to transmit water and indicates the suitability of an aquifer as a water-supply source. For this study, transmissivity values were determined by estimating saturated thickness (b) and hydraulic conductivity (K) from information in drilling logs. Drilling log records were obtained from previously published reports (Johnston and Dickerman, 1974a,b,c), from the GWSI database, and from unpublished water-well logs on file at the USGS Massachusetts-Rhode Island Water Science Center. The drilling logs contained 69 different descriptions of soil class/lithology. Each described lithology was placed in one of six categories and assigned a $\mathrm{K}$ value (table 1) based on earlier studies (Dickerman and Bell, 1993; Dickerman and others, 1990; Dickerman and others, 1997; Johnston and Dickerman, 1974a,b; Rosenshein and others, 1968). Silt, clay, till, and bedrock were assumed to have very low $\mathrm{K}$ of less than $10^{-4} \mathrm{ft} / \mathrm{d}$ and were assigned a value of zero when calculating transmissivity. Observed saturated intervals were recorded and $\mathrm{T}$ values were calculated using equation 1 below. In cases in which drilling logs did not indicate a water level, a transmissivity value was calculated using a water-table altitude estimated from the contours shown on plate 1 .

$$
T=\sum_{i=1}^{\mathrm{n}} b_{i} K_{i}
$$

where $n=$ number of lithologic units,

$i=$ lithologic unit indicator,

$b_{i}=$ saturated thickness of unit $i$, and

$K_{i}=$ hydraulic conductivity of unit $i$.

Equation 1 sums up the contribution to aquifer transmissivity from each permeable layer encountered when drilling a well. Values from 533 wells in the basin were used to construct a map of transmissivity of the sand and gravel aquifer. Transmissivity values greater than $50 \mathrm{ft}^{2} / \mathrm{d}$ are plotted on plate 2 . Forty-eight percent of the transmissivity values were based on data from the Johnston and Dickerman studies (1974a,b,c).

Table 1. Lithologic categories and assigned hydraulic conductivity values in the Blackstone River Basin, northern Rhode Island.

$[<$, less than $]$

\begin{tabular}{lc}
\hline \multicolumn{1}{c}{ Lithologic category } & $\begin{array}{c}\text { Hydraulic conductivity, } \\
\text { in feet per day }\end{array}$ \\
\hline Silt, clay, till, and bedrock & $<10^{-4}$ \\
Silty sand & 10 \\
Fine to medium sand & 50 \\
Medium to coarse sand & 100 \\
Sand and gravel & 200 \\
Coarse gravel & 400 \\
\hline
\end{tabular}


RI-LIW-84
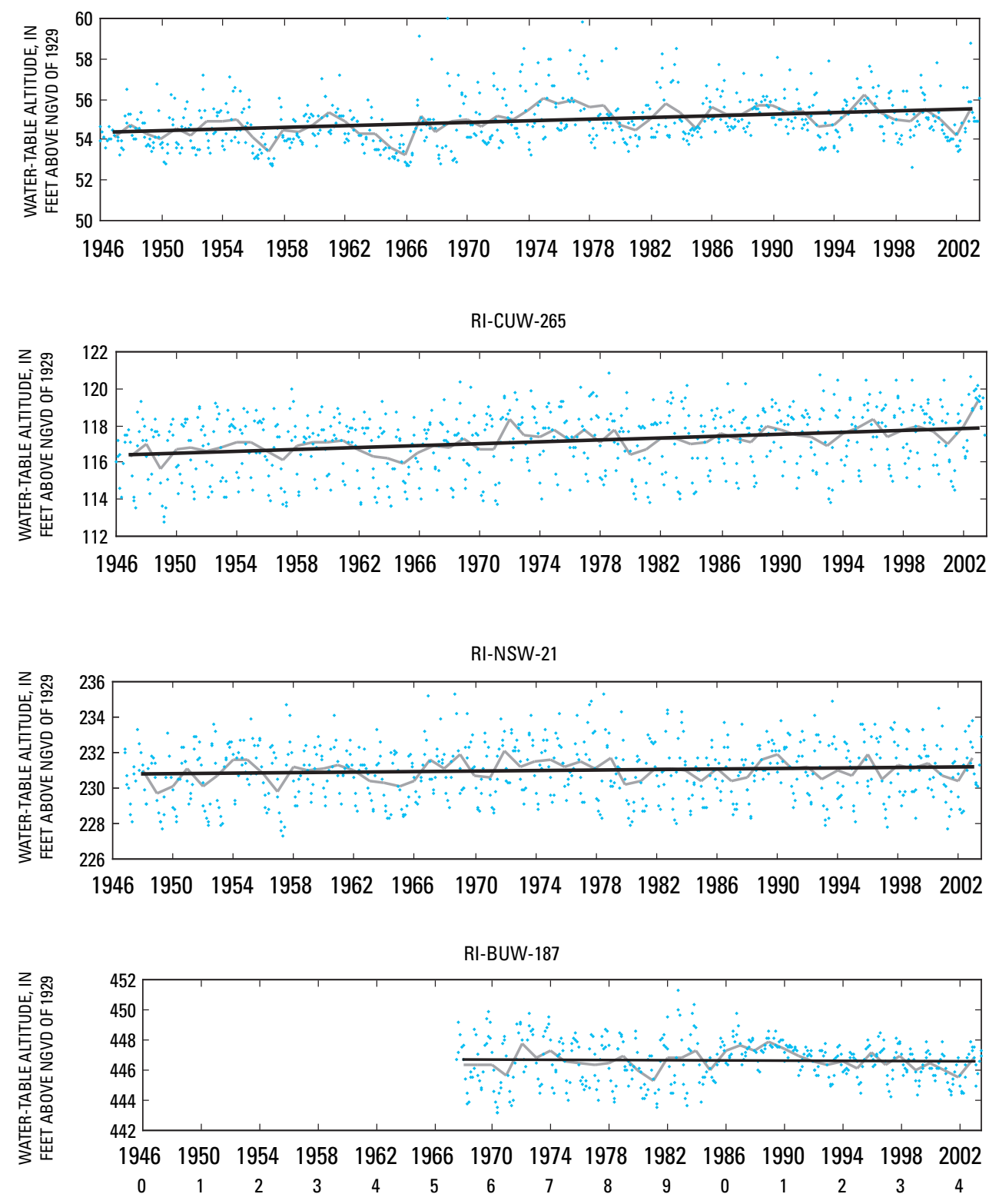

\section{EXPLANATION}

Annual average linear regression

Annual average watertable altitude

Water-table altitude

Figure 2. Water-table altitudes for the 1940s through 2003 in wells RI-LIW-84, RI-CUW-265, RI-NSW-21, and RI-BUW-187, Blackstone River Basin, northern Rhode Island. 


\section{Ground-Water Levels and Transmissivity in the Blackstone River Basin in Northern Rhode Island}

The water-level and transmissivity data were analyzed for spatial and temporal trends. The findings are discussed below with emphasis on their relation to water-supply availability.

\section{Ground-Water Levels}

The water level at any point in an aquifer can change over time. Periodic changes in ground-water levels occur in response to seasonal variations in precipitation and evapotranspiration. Other factors that can affect ground-water levels include changes in land use, ground-water and surface-water withdrawals, and wastewater disposal.

Changes in water levels in long-term observation well RINSW-21 give an example of typical seasonal patterns

(fig. 3) for the period 1947 to 2003 . Water levels in the aquifer are lowest during the late summer and early fall and highest during the early spring. Well RI-NSW-21 has an annual average water-level fluctuation of $3.6 \mathrm{ft}$, which is typical of wells in stratified glacial deposits.

\section{Spatial Patterns}

Water levels in the sand and gravel aquifer are higher in the western part of the study area where land-surface altitudes also are high. The highest ground-water levels in the study area, more than $700 \mathrm{ft}$ above NGVD 1929, are near Burlingame Reservoir in the town of Glocester. The lowest groundwater levels, less than $100 \mathrm{ft}$ above NGVD 1929, are near Central Falls, where the Blackstone River empties into the Seekonk River.

Water-table altitudes are affected by altitudes of nearby streams. Local patterns show that water-table altitudes decrease as ground water moves from ridge tops to valley bottoms. Near streams and lakes, water-table altitudes are nearly the same as surface-water altitudes.

\section{Long-Term Trends}

Water-table altitudes have risen in the study area from the 1940s through 2003; three of the four long-term observation wells in the basin show increasing altitudes and the fourth shows no trend (fig. 2). Annual average altitudes in wells CUW-265, LIW-84, and NSW-21 rose from the 1940s to 2003 by $1.1,1.4$, and $0.4 \mathrm{ft}$, respectively, whereas the altitude in BUW-187 declined $0.1 \mathrm{ft}$ between 1968 and 2003. Well NSW-

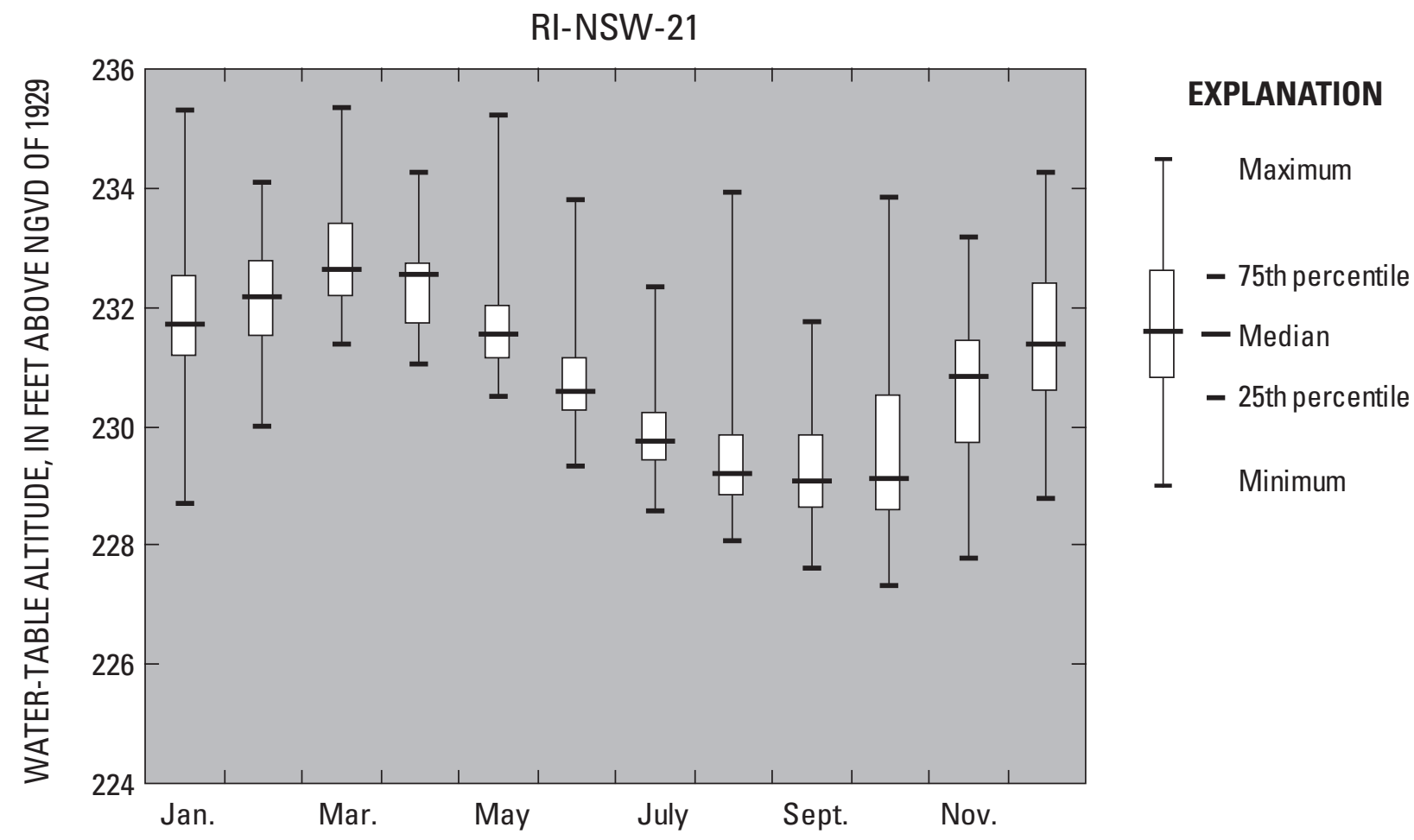

Figure 3. Seasonal changes in the altitude of the water table in North Smithfield well 21 (RI-NSW-21) for the 1940s through 2003, Blackstone River Basin, northern Rhode Island. Well location shown on figure 1 and plate 1. 
21 is reported to have been affected by pumping for domestic water supplies from 1947 to 1980 (Socolow and others, 2005).

Data describing land-use change, water withdrawals, evapotranspiration, and wastewater disposal during the past 60 years are insufficient to determine how these factors affected the altitude of the water table. A likely explanation for rising water-table altitudes is the precipitation increase in the Rhode Island part of the Blackstone River Basin (fig. 4). At climatological station 379423 in Woonsocket, R.I., the only long-term station in the basin, annual precipitation increased by about 11 in. from 1949 to 2003 (fig. 4) on the basis of a linear-trend fit to annual precipitation data (National Climate Data Center, 2003). Other stations within $20 \mathrm{mi}$ of the basin also show increased annual precipitation. Station 376698 in Providence, R.I., showed a change of +1.2 in. from 1949 to 2001; station 198367 in Taunton, Mass., showed a change of +7.8 in. from 1949 to 1993; and station 199316 in West Medway, Mass., showed a change of $+7.6 \mathrm{in}$. from 1957 to 2000 , based on linear-trend fits to annual precipitation data (National Climate Data Center, 2003). These long-term increases in Blackstone River Basin precipitation are further supported by streamflow records from 1929 to 2000 for the Blackstone River at the Woonsocket, R.I., (USGS station 01112500), which show an increase in streamflow of about 18 percent (Robinson and others, 2003).
The annual precipitation increase of about $11 \mathrm{in.} \mathrm{recorded}$ at Woonsocket would be expected to raise the ground-water level in the unconfined aquifers of the basin. A rough estimate of the expected ground-water-level rise caused by an increase in recharge can be obtained from a modification of the solution to Forchheimer's equation (Bear, 1972, eq. 8.2.26):

$$
m^{\prime}=N^{\prime} L^{2} / 8 K h_{0}
$$

where $m^{\prime}=$ change in ground-water level at groundwater divide (L),

$N^{\prime}=$ change in recharge rate $(\mathrm{L} / \mathrm{T})$,

$L=$ distance between drainages $(\mathrm{L})$,

$K=$ hydraulic conductivity $(\mathrm{L} / \mathrm{T})$, and

$h_{0}=$ height of drainage stage above the bottom of the aquifer (L).

Substituting $N^{\prime}=0.92 \mathrm{ft} / \mathrm{yr}$ (under the assumption that all additional precipitation goes to recharge), $L=2,430 \mathrm{ft}$ (an estimate of average distance between drainage streams obtained by dividing the basin area by $1.361 \times 10^{10} \mathrm{mi}$, the total length of stream centerlines in the study area), $K=100 \mathrm{ft} / \mathrm{d}$ (an estimate of average hydraulic conductivity based on the transmissivity data discussed above), and $h_{0}=40 \mathrm{ft}$ (an estimate of aquifer thickness below streams) yields

$$
m^{\prime}=0.5 \mathrm{ft} \text {. }
$$

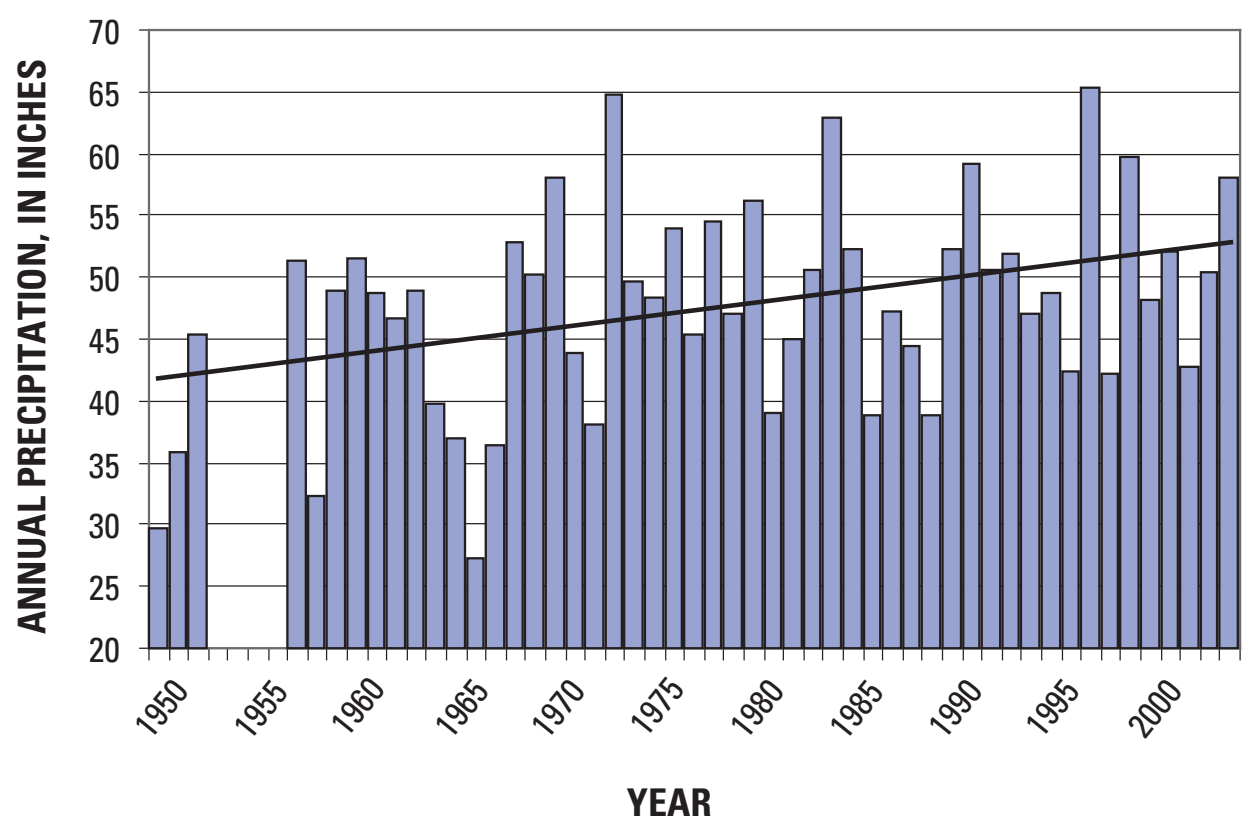

Figure 4. Annual precipitation at climatological station 379423 in Woonsocket, Rhode Island for 1949-2003. Straight line is the linear regression line. Location of station shown on figure 1 and plate 1. 
Equation 2 produces a calculated ground-water-level rise of $0.5 \mathrm{ft}$, which would occur halfway between two drainages (streams). Moving from a ground-water-level high toward a drainage, the ground-water-level rise would lessen and be zero at the drainage. The calculated rise of $0-0.5 \mathrm{ft}$ accounts for a part of the observed ground-water-level rises of 0 to $1.4 \mathrm{ft}$. So the observed ground-water-level rise is likely due in part to increased precipitation, but other factors are also probably contributing. More detailed study would be needed to confirm this hypothesis.

\section{Uncertainty in Water Levels}

Water levels were contoured for stratified glacial deposits in the study area (plate 1). Contours were initially produced with an automated routine and then checked and manually modified. Uncertainty in the water-table altitudes shown on the plate is due to the varied timing of the measurements, measurement errors, variations in water-table altitude with well depth, changes caused by pumping, and interpolation errors. Because water levels have risen over time, older measurements will tend to underestimate the current levels. Measurements were made during different seasons of the year, which adds further variability. The variation of water levels over time at one location is illustrated by measurements at well RI-NSW 21. Based on 685 water-level measurements taken from the 1940s through 2003 (fig. 3), the difference between maximum and minimum individual values is $8.0 \mathrm{ft}$ and the difference between maximum and minimum monthly mean values (March-September) is $3.7 \mathrm{ft}$.

Further assessment of uncertainty can be made by comparing water levels measured in closely spaced wells. There are 298 pairs of water-level measurements made at varying times in wells less than $100 \mathrm{ft}$ apart horizontally. Levels measured less than $100 \mathrm{ft}$ apart horizontally in the same aquifer are expected to agree quite closely, for example with a difference of less than $3 \mathrm{ft}$, unless there is nearby ground-water pumping, the wells are in steep terrain, or the wells are screened at different depths. For each of the 298 well pairs, water levels were subtracted from each other, yielding 298 differences. The average water-level difference is $15.5 \mathrm{ft}$ and the standard deviation is $24.7 \mathrm{ft}$. Using these differences as an indication of uncertainty in water levels suggests that the actual level can be expected to vary from the mapped level, at any point, by $15 \mathrm{ft}$ (plate 1).

\section{Movement of Ground Water}

Ground water in the study area flows towards major streams and rivers, which occupy regional topographic lows. The direction of ground-water flow, inferred from the contours of the altitude of the water table, is indicated by black arrows on plate 1. Ground water generally discharges to streams, ponds, and wetlands unless flowing to a pumped well. Exceptions to this pattern may be found locally where a stream crosses a transition to more permeable aquifer sediments, causing the stream to lose water to the aquifer and ground water to flow away from the stream. No such transitions are seen on plate 1 , in part because the spatial scale is too coarse to show such local effects.

\section{Transmissivity}

For a given aquifer thickness, transmissivity is controlled by lithology. Sand and gravel deposits generally have higher transmissivity than fine-grained stratified glacial deposits, till deposits, or bedrock. Estimated transmissivity values in the study area range from near zero to more than $25,000 \mathrm{ft}^{2} / \mathrm{d}$. Of the total of 553 transmissivity values, 152 (28 percent) are less than $50 \mathrm{ft}^{2} / \mathrm{d}$. Transmissivity values less than $50 \mathrm{ft}^{2} / \mathrm{d}$ are mainly in areas where bedrock or till is at the land surface. Statistics for the 390 transmissivity values in the sand and gravel aquifer are shown in table 2 .

Table 2. Descriptive statistics for transmissivity values in the sand and gravel aquifer, Blackstone River Basin, northern Rhode Island.

$[<$, less than $]$

\begin{tabular}{lc}
\hline Statistic & $\begin{array}{c}\text { Transmissivity, in feet } \\
\text { squared per day }\end{array}$ \\
\hline Count & 390 \\
Mean & 4,420 \\
Minimum & $<50$ \\
$10^{\text {th }}$ percentile & 200 \\
$25^{\text {th }}$ percentile & 1,000 \\
Median & 2,990 \\
$75^{\text {th }}$ percentile & 6,690 \\
$90^{\text {th }}$ percentile & 10,980 \\
Maximum & 22,650 \\
\hline
\end{tabular}


Transmissivity values greater than approximately 1,400 $\mathrm{ft}^{2} / \mathrm{d}$ "represent good aquifers for water well exploitation" (Freeze and Cherry, 1979, p. 60). Of the 357 transmissivity values in the sand and gravel aquifer greater than $50 \mathrm{ft}^{2} / \mathrm{d}, 74$ percent of the values are greater than $1,400 \mathrm{ft}^{2} / \mathrm{d}$.

Spatial patterns of transmissivity are predominately controlled by the thickness of stratified glacial deposits. The greatest transmissivity values are seen in the valleys of the Branch, Chepachet, Nipmuc, and Blackstone Rivers, where deep sand and gravel deposits are found (plate 2) and where wells may induce infiltration from surface-water bodies. Transmissivity values greater than $10,000 \mathrm{ft}^{2} / \mathrm{d}$ are seen in every town in the study area except Smithfield, within which no transmissivity measurements were made within the study area, and which has very little area with stratified glacial deposits. Based on the contours on plate 2 , the stratified glacial deposits in about $22 \mathrm{mi}^{2}$, or 16 percent of the study area, have transmissivity values greater than $1,000 \mathrm{ft}^{2} / \mathrm{d}$.

Although plates 1 and 2 do not show contours of watertable altitude or transmissivity in areas of till and bedrock, ground water is present in these areas. Areas of till and bedrock generally have lower transmissivity values and well yields, but some water-supply wells are located in these areas to serve small communities, small businesses, or private households. This study does not include an analysis of till and bedrock areas and should not be used to infer transmissivity values or ground-water levels for such areas.

Because the transmissivity map in this study is based on most of the same data used by Johnston and Dickerman (1974a,b) to construct their transmissivity maps, there are many similarities between the maps. Of the 533 transmissivity values used to construct plate 2, 48 percent, or 256 values, were also used by Johnston and Dickerman. Differences between plate 2 and the 1974 maps include the display of transmissivity point data, display of the entire Rhode Island part of the Blackstone River Basin, and modified transmissivity contours in those areas where additional transmissivity data were available. Areas of high transmissivity (greater than $5,000 \mathrm{ft}^{2} / \mathrm{d}$ ) on plate 2 differ somewhat from the ground-water reservoirs identified by the state of Rhode Island (Rhode Island Statewide Planning Program,1979; Rhode Island
Department of Environmental Management, 1991). Along the Blackstone River in the southern part of Cumberland and in the Chepachet River valley, the new map shows less extensive areas of high transmissivity. In other parts of the basin, such as near the Pascoag and Wilson Reservoirs, the areas of high transmissivity are more extensive than the previously mapped ground-water reservoirs.

\section{Summary}

This study of ground-water resources in the Rhode Island portion of the Blackstone River Basin was performed in cooperation with the Rhode Island Water Resources Board. Spatial and temporal trends in ground-water levels are presented, and transmissivity data are compiled into a contour map that presents a more regional view of aquifer transmissivity than do previous maps.

Ground-water levels rose in the study area from 1947 to 2003. Water levels are known to decline locally near pumping wells, but these declines are limited in areal extent by the narrow geometry of the sand and gravel aquifers and the proximity of surface water to most wells in the study area. The measured increase in precipitation rate, about 11 inches per year from 1949 to 2003 in Woonsocket, R.I., is likely a contributor to the observed water-level increases. Data from four wells with long-term water-level records have good temporal detail, but because long-term data are available from only a small number of wells in the study area, it is not known if water levels have risen throughout the watershed.

Transmissivity is greatest in areas of thick sand and gravel deposits, which typically occur in stream valley bottoms. Some high-transmissivity wells are seen in areas not previously identified by the state of Rhode Island as groundwater reservoirs. Other areas show lower transmissivity than the previously mapped ground-water reservoirs. The contours in plate 2 and wells listed in the Appendix give more detailed and more accessible information about transmissivity than has previously been available for the Blackstone River Basin in Rhode Island. 


\section{References Cited}

Barlow, L.K., 2003, Estimated water use and availability in the lower Blackstone River Basin, northern Rhode Island and south-central Massachusetts, 1995-1999: U.S. Geological Survey Water-Resources Investigations Report 03-4190, $75 \mathrm{p}$.

Bear, J., 1972, Dynamics of fluids in porous media: New York, Dover Publications, 764 p.

Dickerman, D.C., and Bell, R.W., 1993, Hydrogeology, water quality, and ground-water development alternatives in the Upper Wood River ground-water reservoir, Rhode Island: U.S. Geological Survey Water-Resources Investigations Report 92-4119, 87 p.

Dickerman, D.C., Trench, E.C.T., and Russell, J.P., 1990, Hydrogeology, water quality and ground-water development alternatives in lower Wood River ground-water reservoir, Rhode Island: U.S. Geological Survey Water-Resources Investigations Report 89-4031, 109 p.

Dickerman, D.C., Kliever, J.D., Stone, J.R., 1997, Hydrogeology, water quality, and simulation of ground-water development alternatives in the Usquepaug-Queen ground-water reservoir, Rhode Island: U.S. Geological Survey WaterResources Investigations Report 97-4126, 48 p.

Freeze, R.A., and Cherry, J.A., 1979, Groundwater: Englewood Cliffs, NJ, Prentice Hall, 604 p.

Johnston, H.E., and Dickerman, D.C., 1974a, Availability of ground water in the Branch River basin, Providence County, Rhode Island: U.S. Geological Survey Water-Resources Investigations Report 18-74, 39 p.

Johnston, H.E., and Dickerman, D.C., 1974b, Availability of ground water in the Blackstone River area, Rhode Island and Massachusetts: U.S. Geological Survey WaterResources Investigations Report 4-74, 1 pl.

Johnston, H.E., and Dickerman, D.C., 1974c, Geologic and hydrologic data for the Blackstone River area, Rhode Island, U.S. Geological Survey Hydrologic Bulletin 7, 44 p.
National Climate Data Center, Annual climatological summary, 1948-2003, accessed on Jan. 3, 2005, at http://www. ncdc.noaa.gov/oa/mppsearch.html

Rhode Island Department of Environmental Management, 1991, Policies and procedures for mapping recharge areas to groundwater reservoirs for GAA classification: Providence, Rhode Island, memorandum, unnumbered.

Rhode Island Statewide Planning Program, 1979, Water quality management plan for Rhode Island-Final plan, August, 1979: Providence, Rhode Island, 468 p.

Robinson, K.W., Campbell, J.P., and Jaworski, N.A., 2003, Water-quality trends in New England rivers during the 20th century: U.S. Geological Survey Water-Resources Investigations Report 03-4012, 20 p.

Rosenshein, J.S., Gonthier, J.B., and Allen, W.B., 1968, Hydrologic characteristics and sustained yield of principal ground-water units, Potowomut-Wickford area, Rhode Island: U.S. Geological Survey Water-Supply Paper 1775, $38 \mathrm{p}$.

Socolow, R.S., Comeau, L.Y., and Domenic Murino, Jr., 2005, Water resources data for Massachusetts and Rhode Island, water year 2004: U.S. Geological Survey Water-Data Report MA-RI-04-1, 326 p.

U.S. Fish and Wildlife Service, 1981, Interim regional policy for New England stream flow recommendations: Memorandum from H.N. Larsen, Director, Region 5, U.S. Fish and Wildlife Service, Newton Corner, Massachusetts, 3 p.

U.S. Census Bureau, 2000, Census 2000, accessed on Jan. 4, 2005 at http://www.census.gov/. 


\section{Glossary}

aquifer An underground formation of earth, sand, gravel, or porous stone that yields significant quantities of water to wells or springs.

base flow The water in streams and rivers that has come from ground-water discharge. During periods of little or no precipitation, typically all the water in a stream is base flow.

confined aquifer An aquifer that is covered by a layer of impermeable material, such as rock or clay, so that the water level in a well rises above the top of the aquifer.

evapotranspiration The movement of water from the land surface to the atmosphere. The word is formed by combining "evaporation," meaning the conversion of water from fluid to vapor, and "transpiration," meaning the release of water vapor to the atmosphere by plants. transmissivity A measure of the ability of an aquifer to transmit water; indicates the suitability of an aquifer as a water source. Units are length squared/time, for instance feet squared per day.

unconfined aquifer An aquifer not covered by an impermeable layer in which the water table forms the upper boundary. At the water table the pressure of the water equals the pressure of the atmosphere.

unconsolidated Refers to loose materials such as sand, gravel, and clay that are not cemented together, as opposed to solid rock. 
Appendix. Hydrogeologic Data for the
Blackstone River Basin, Northern Rhode Island 


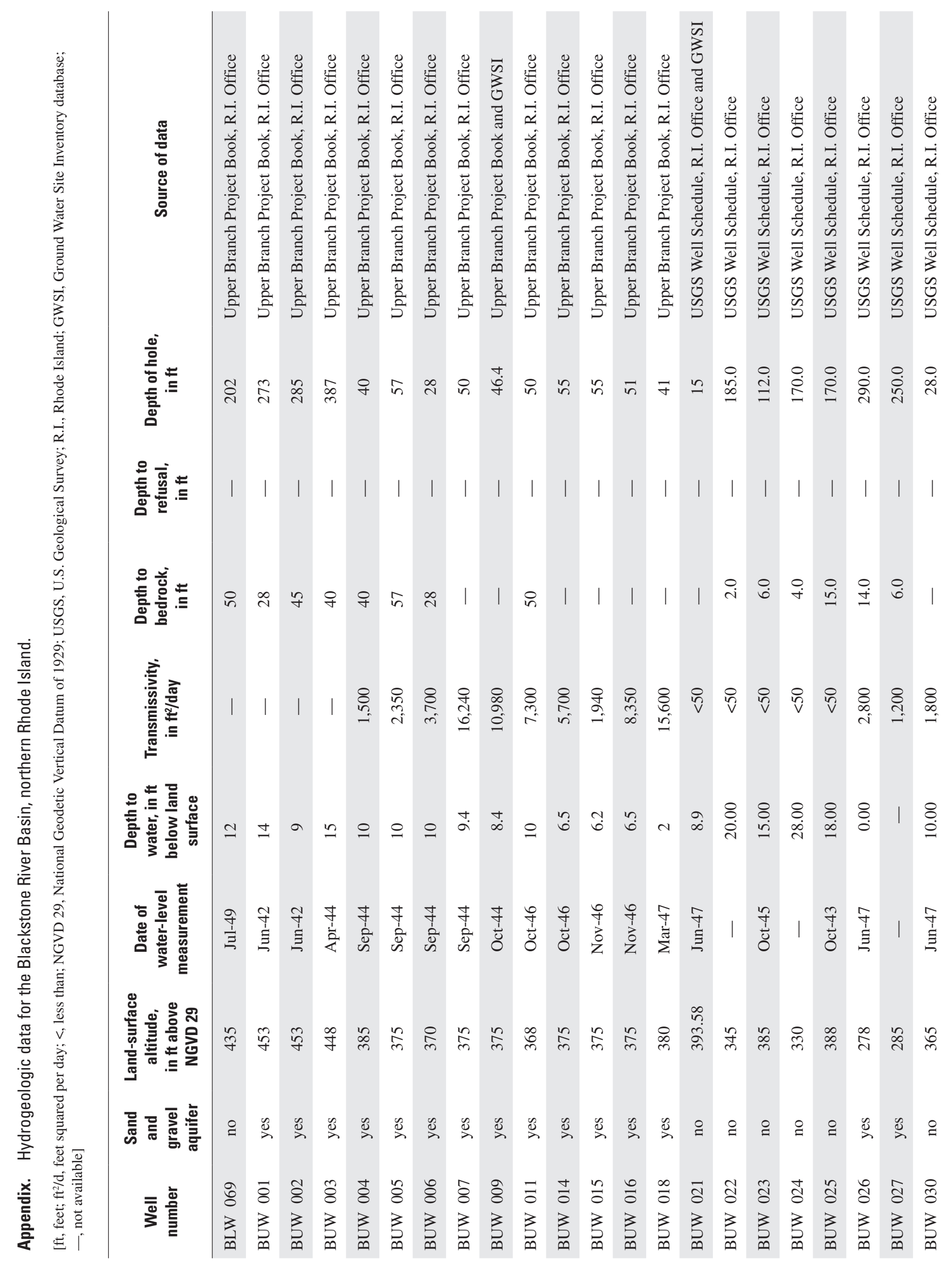




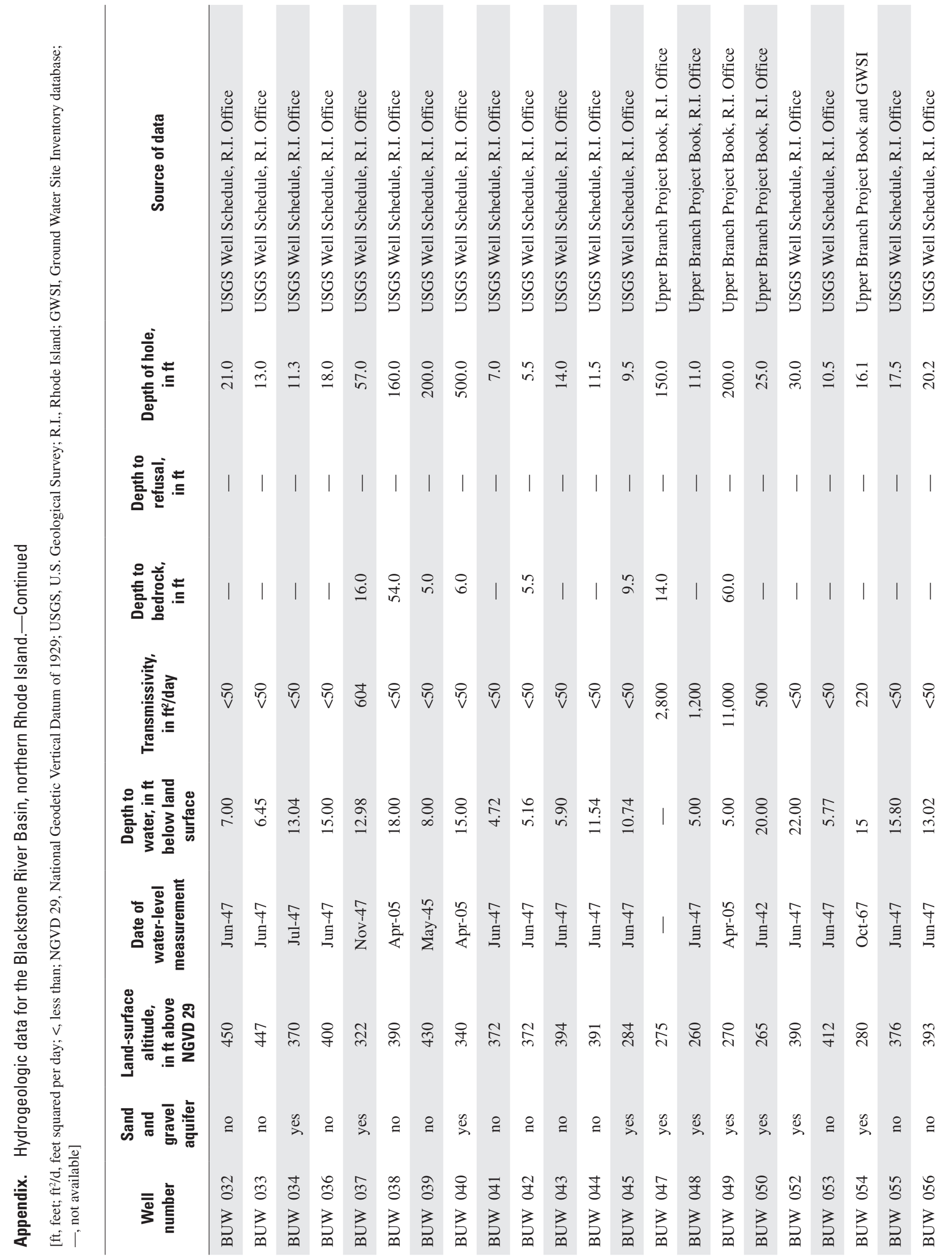




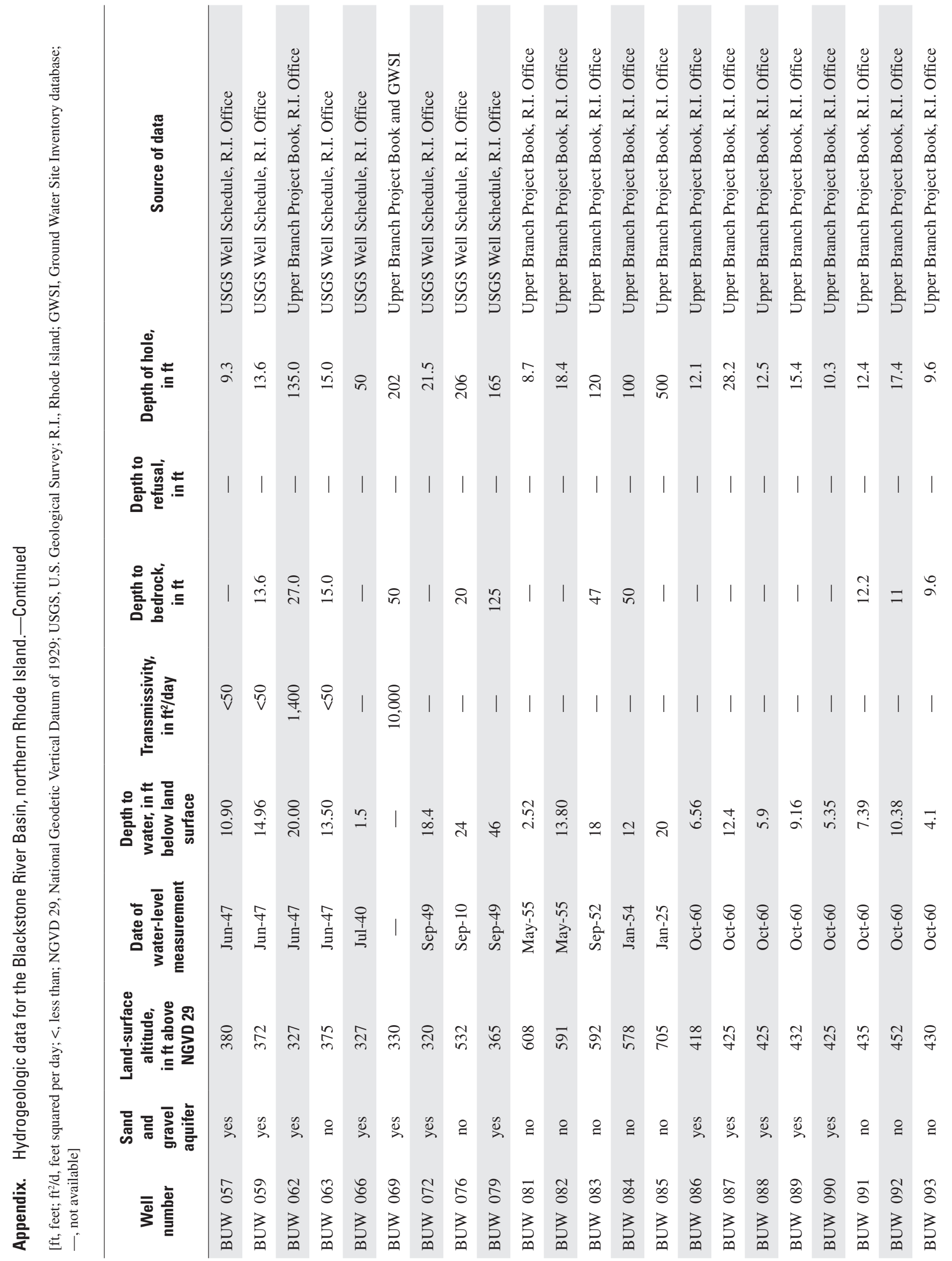




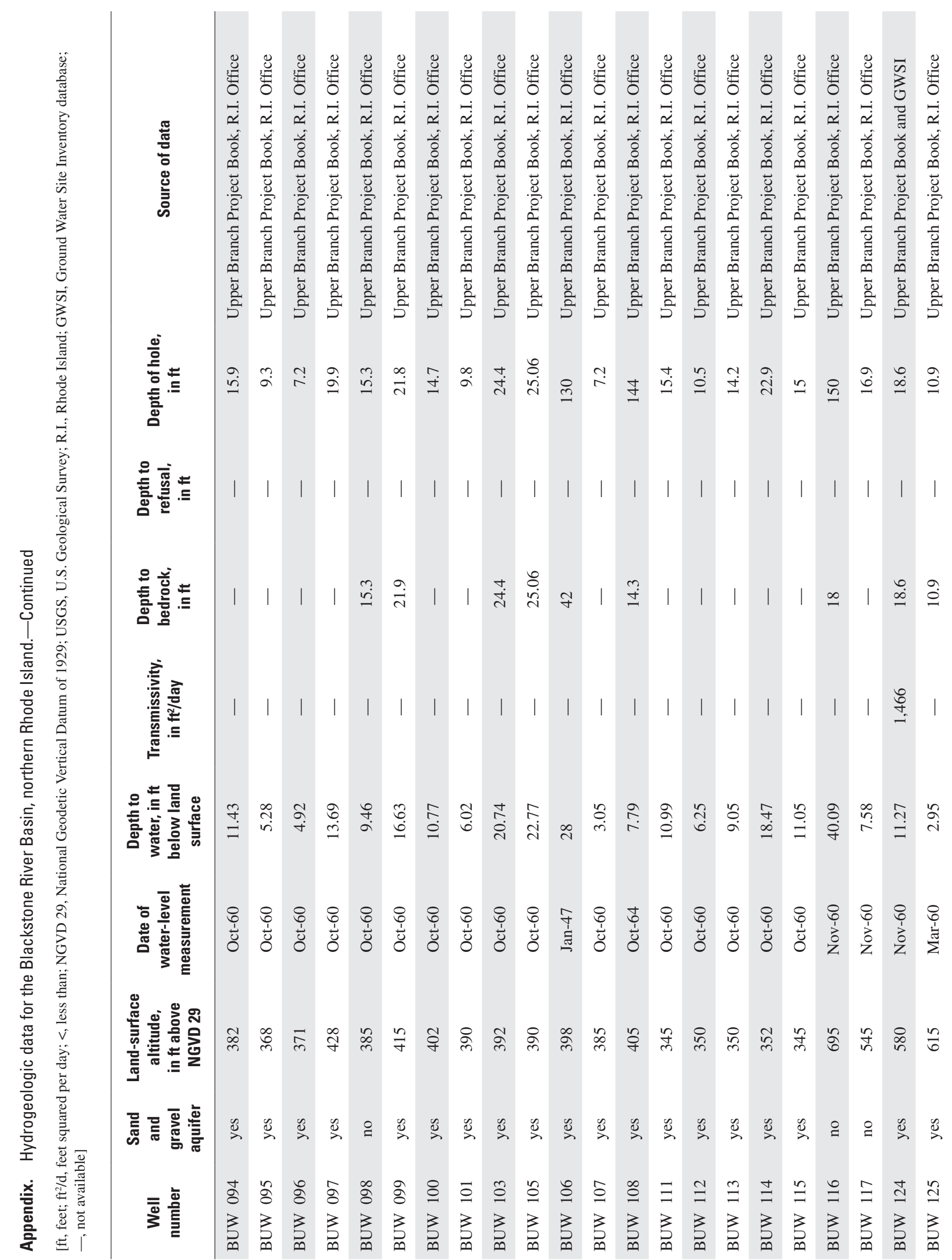




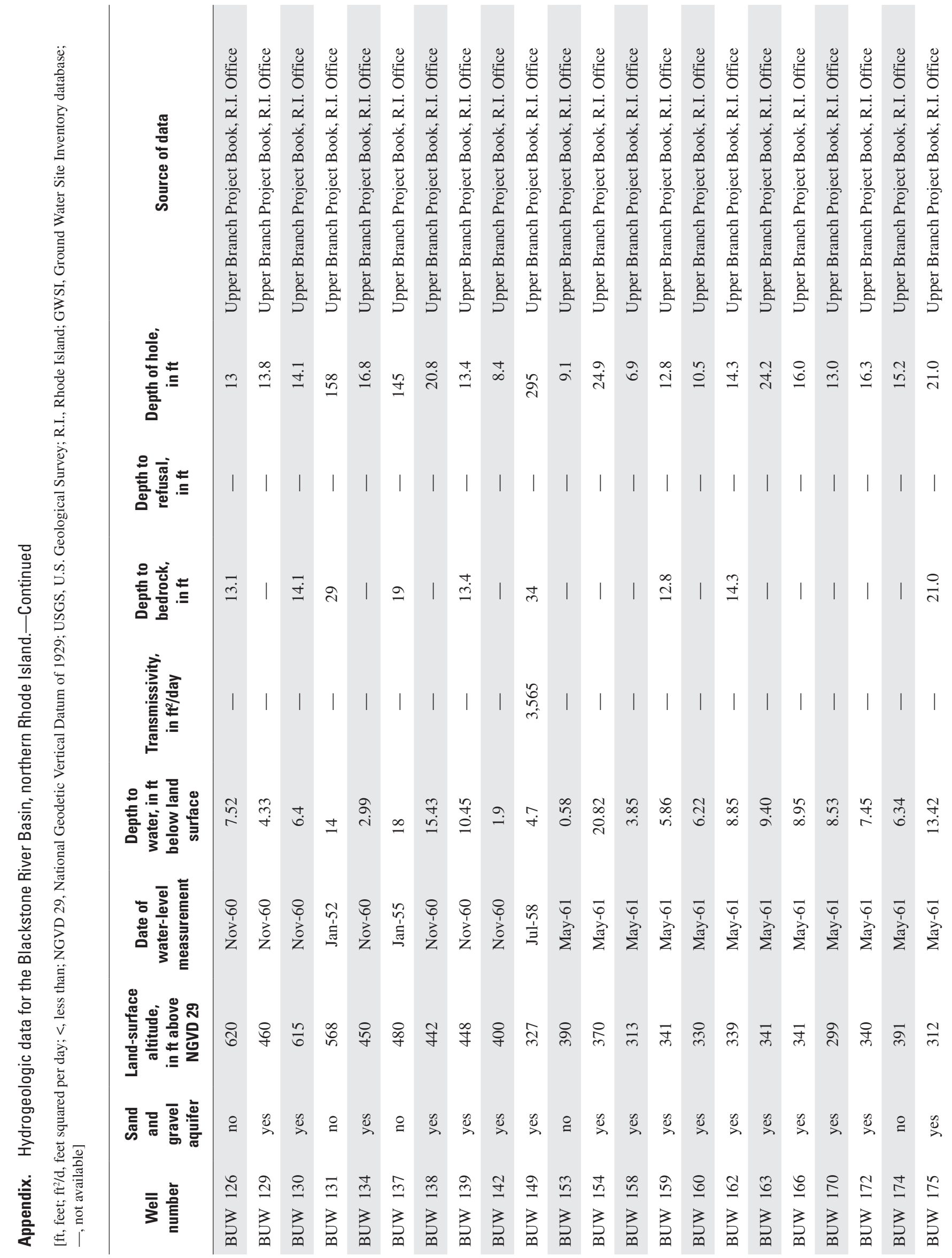




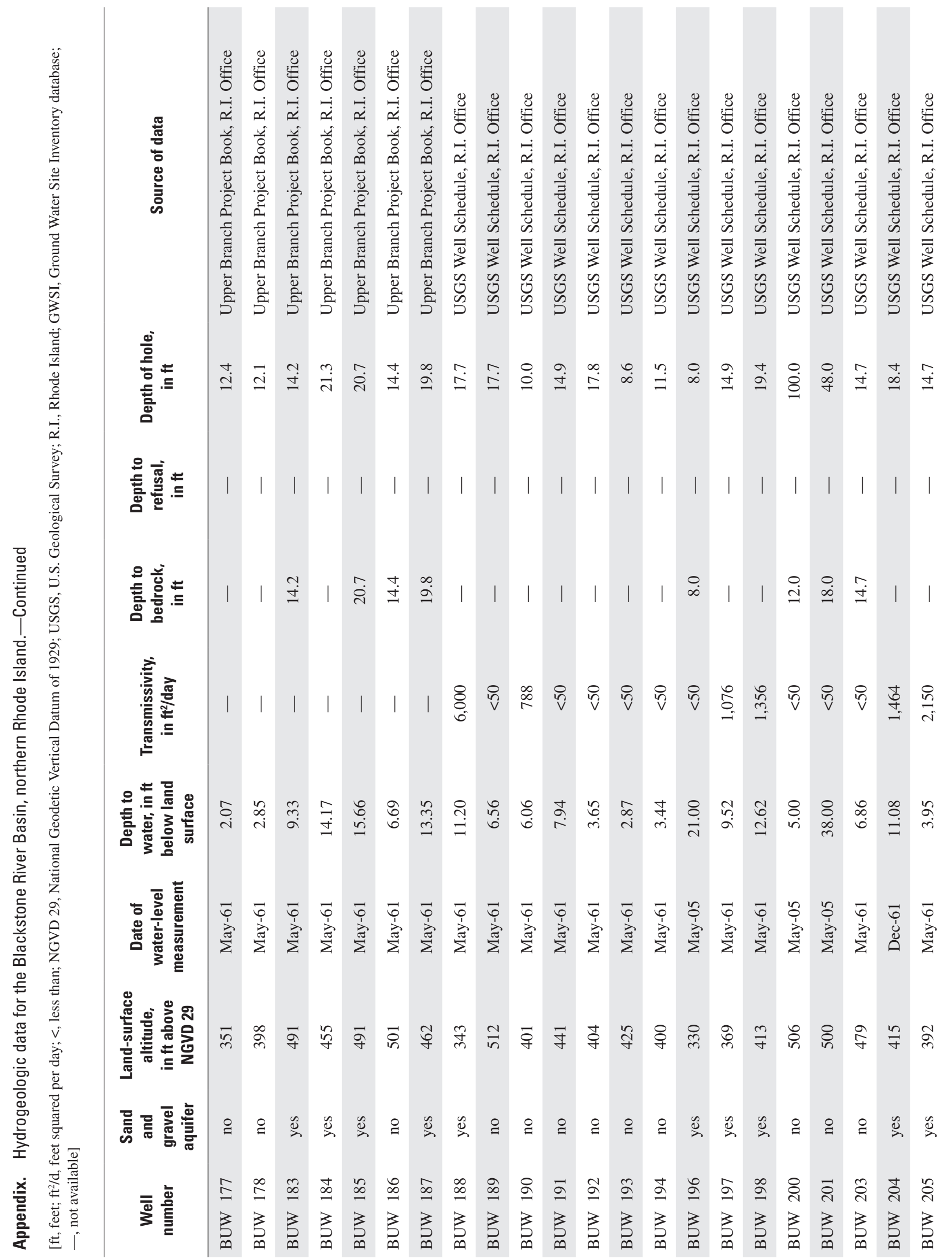




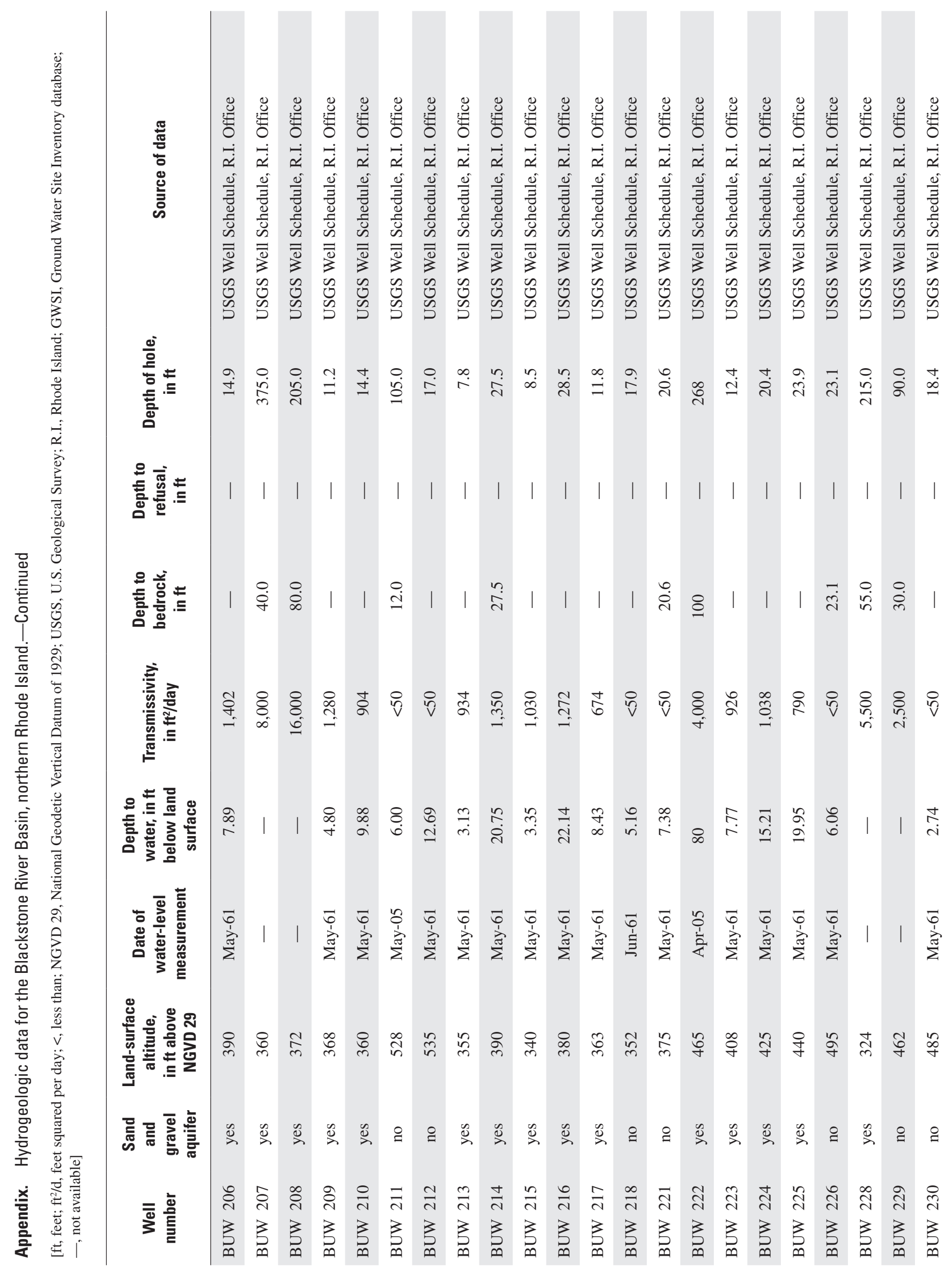




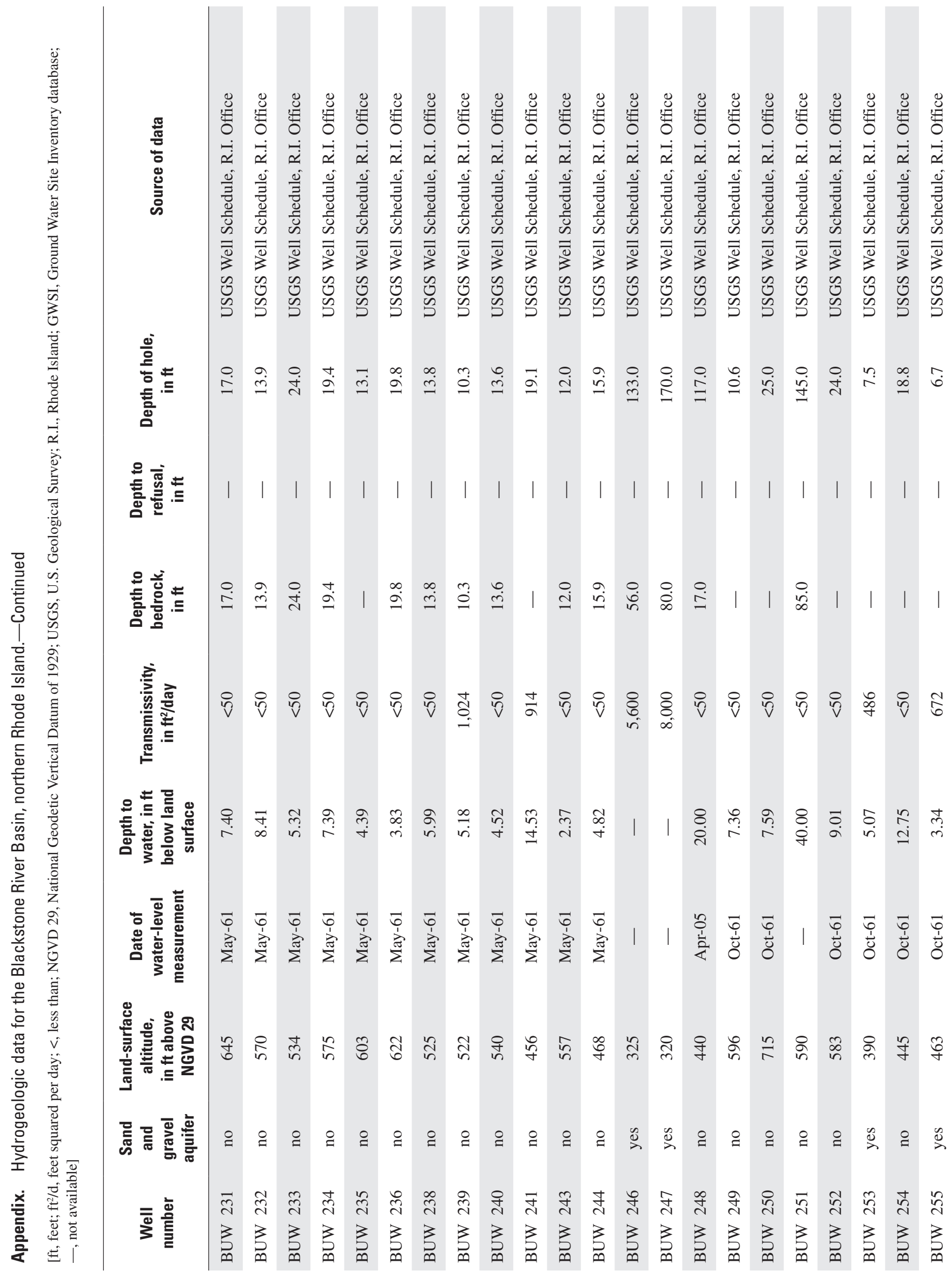




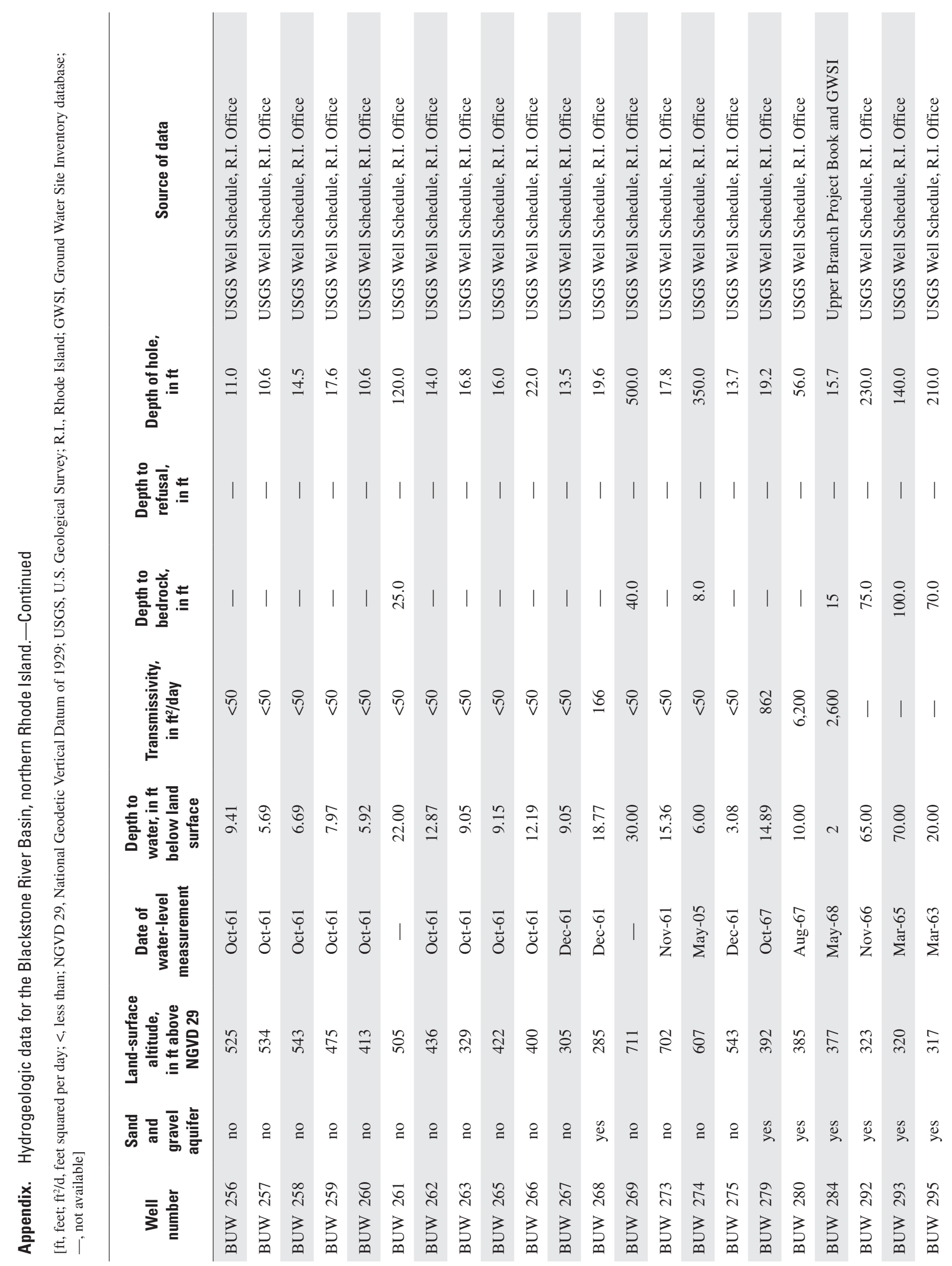




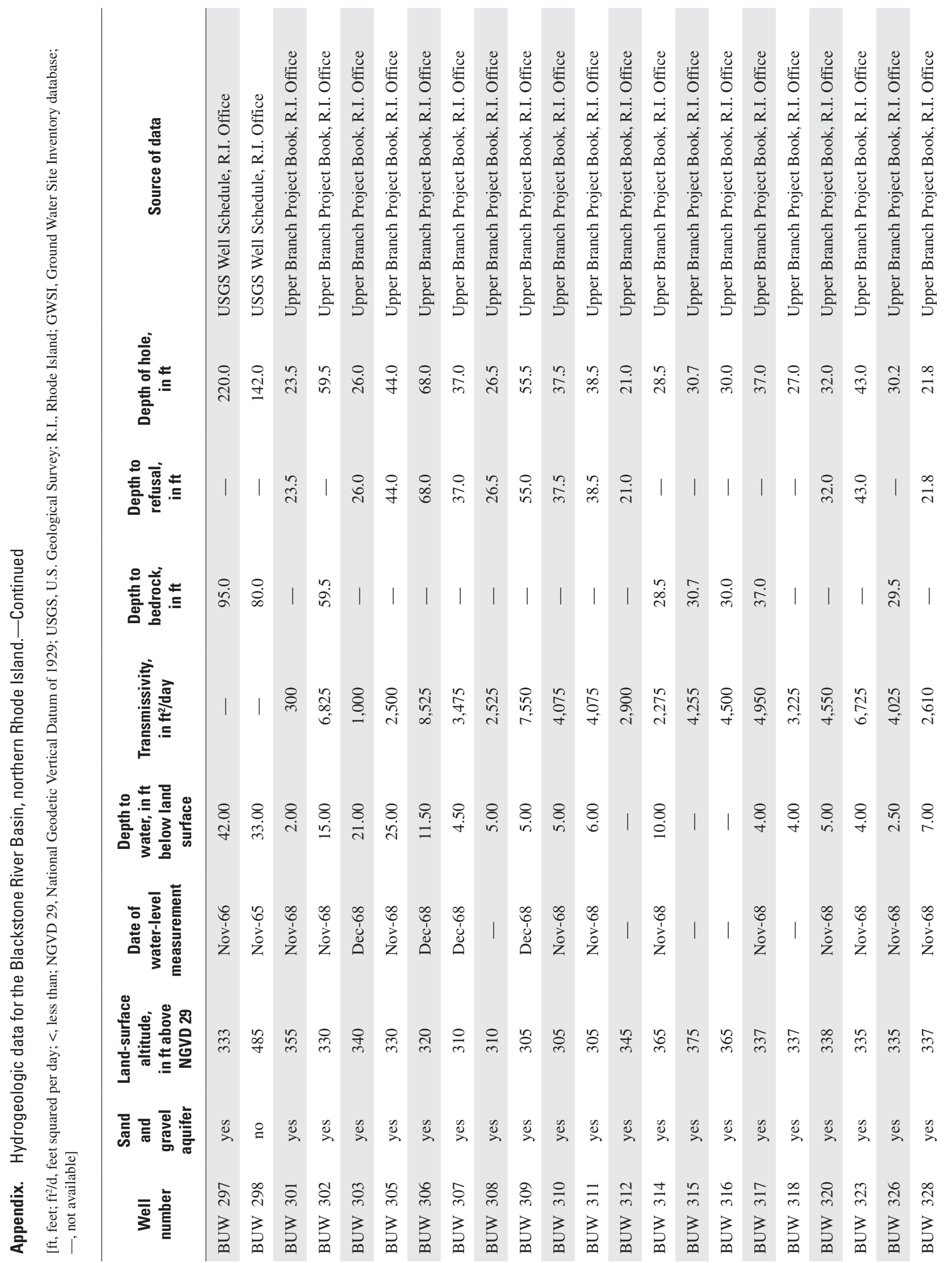




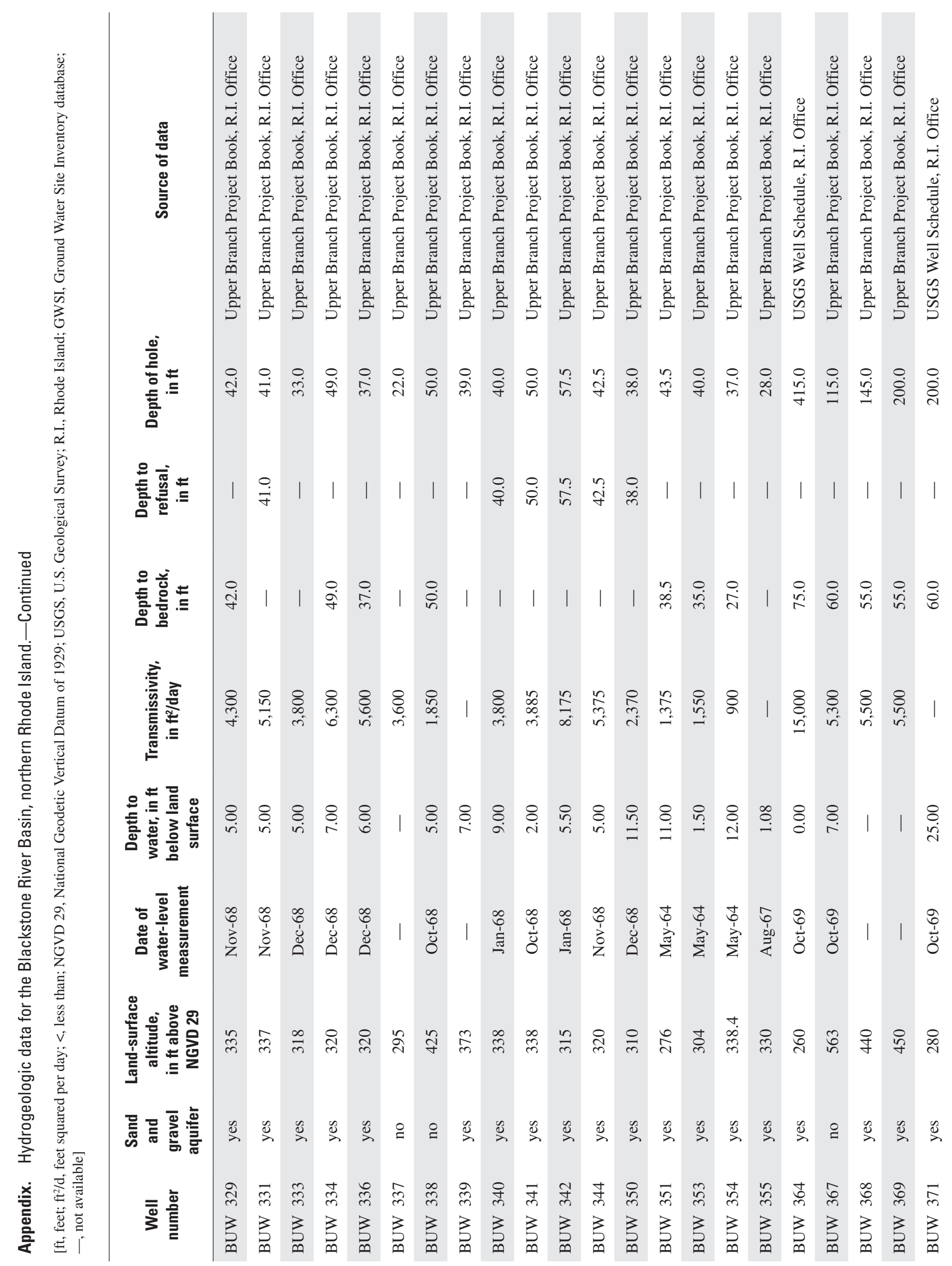




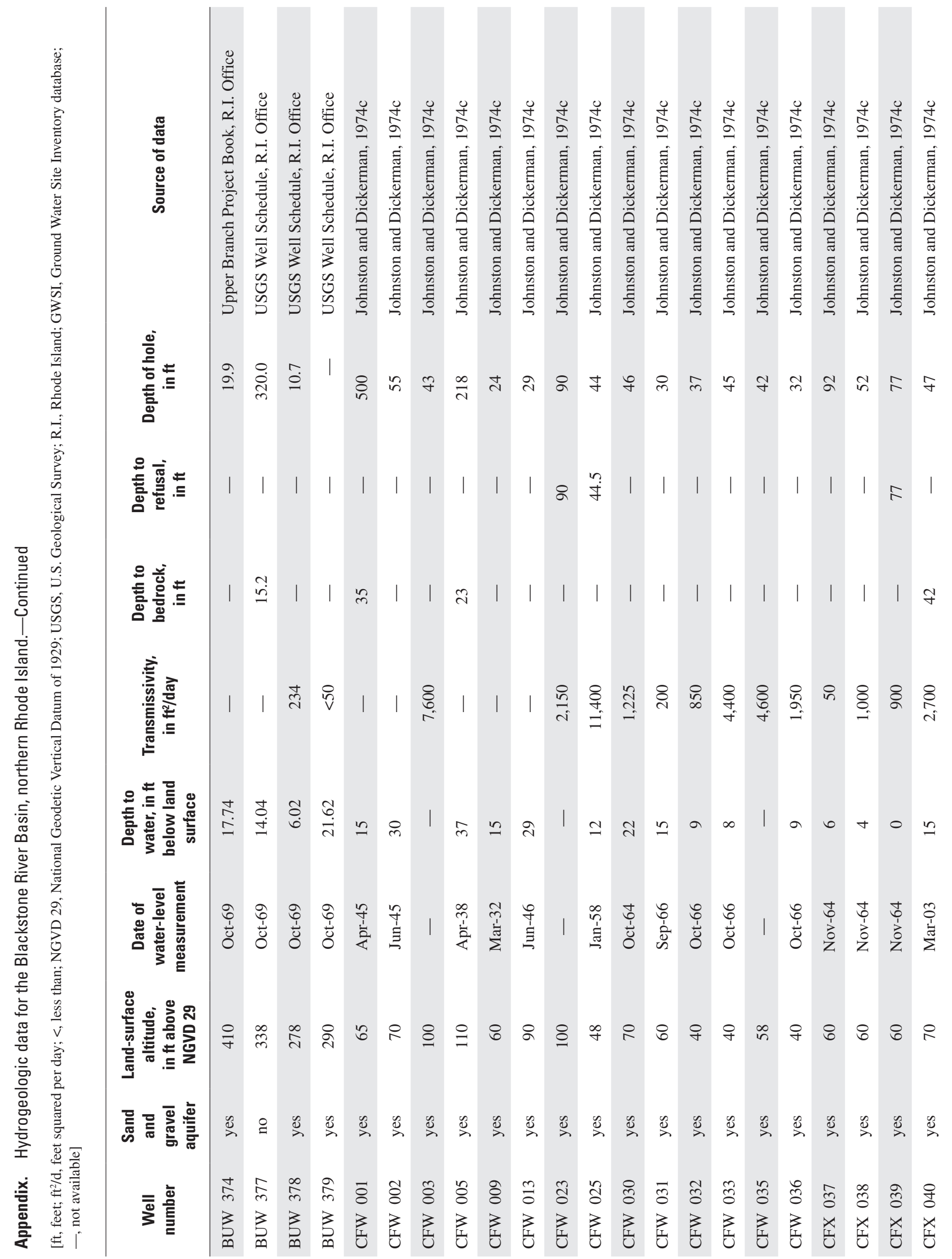




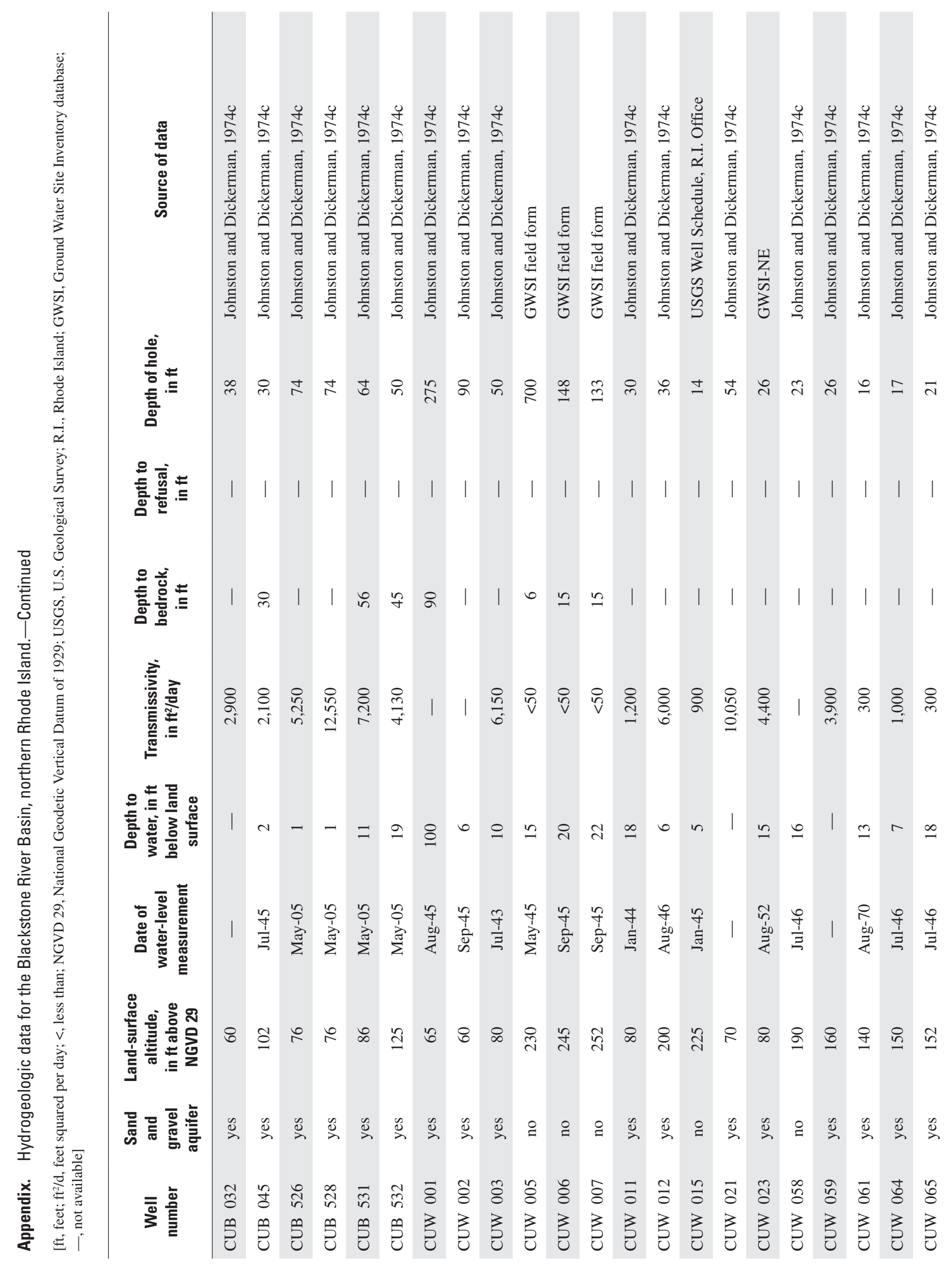




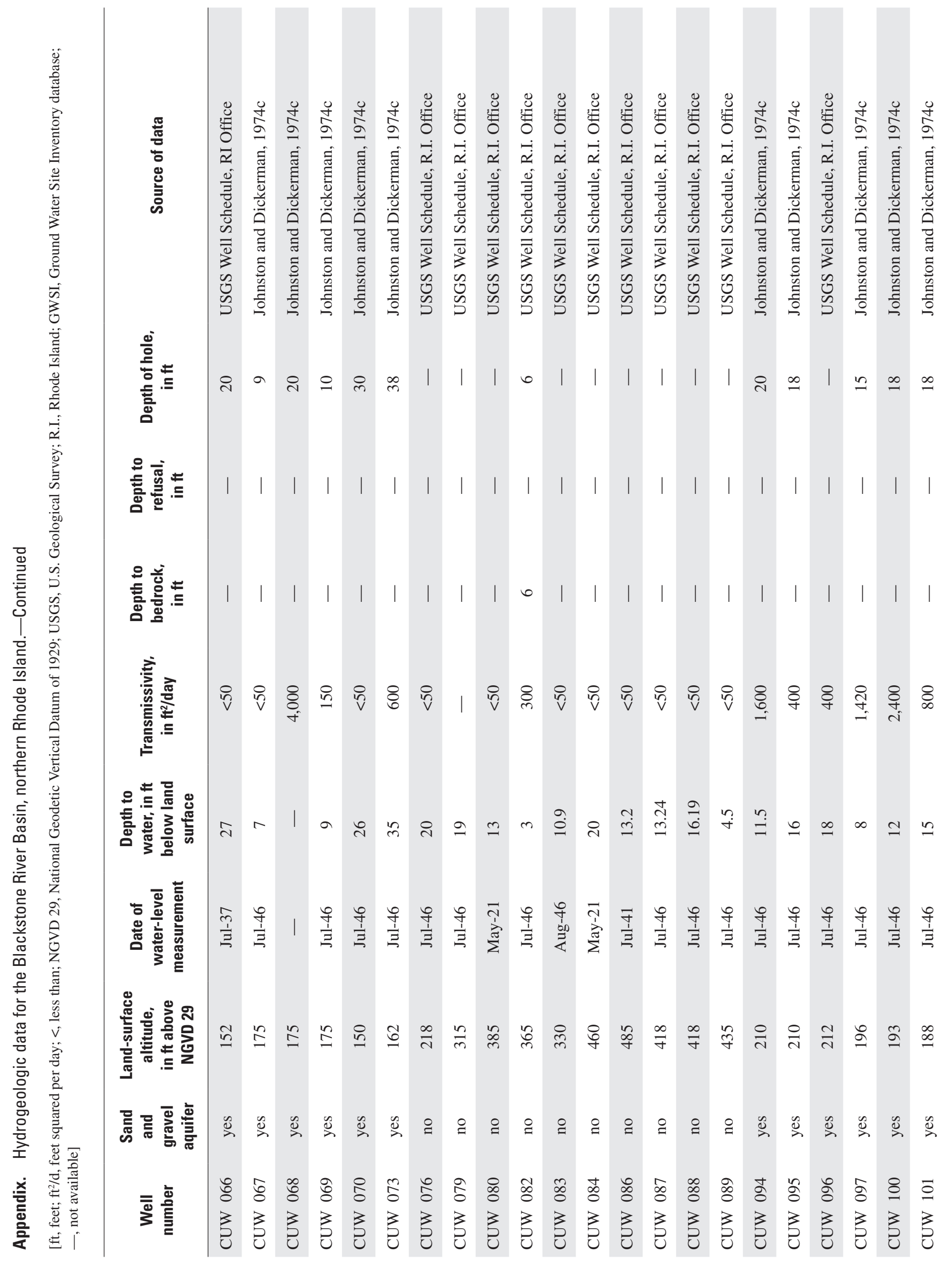




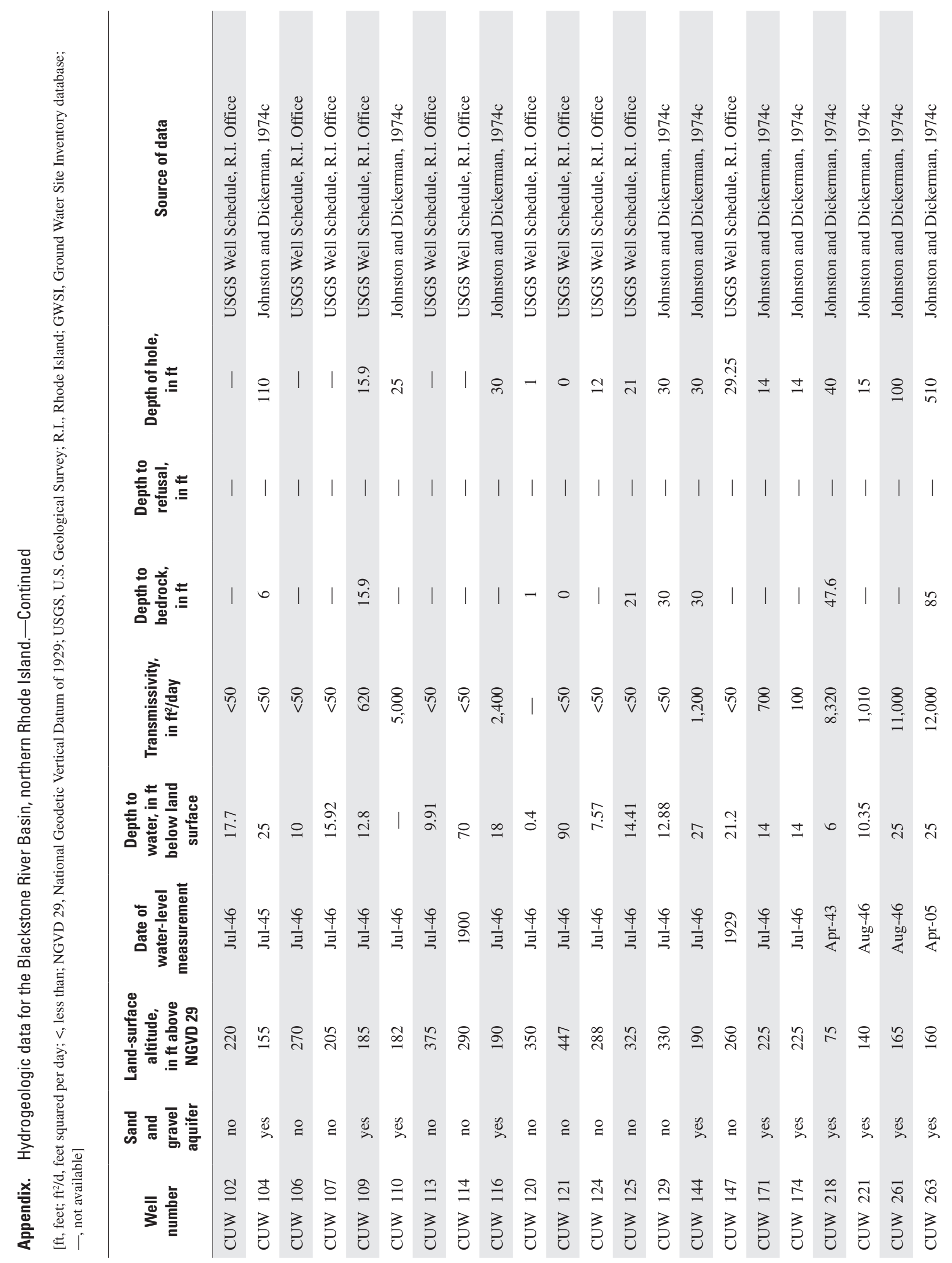




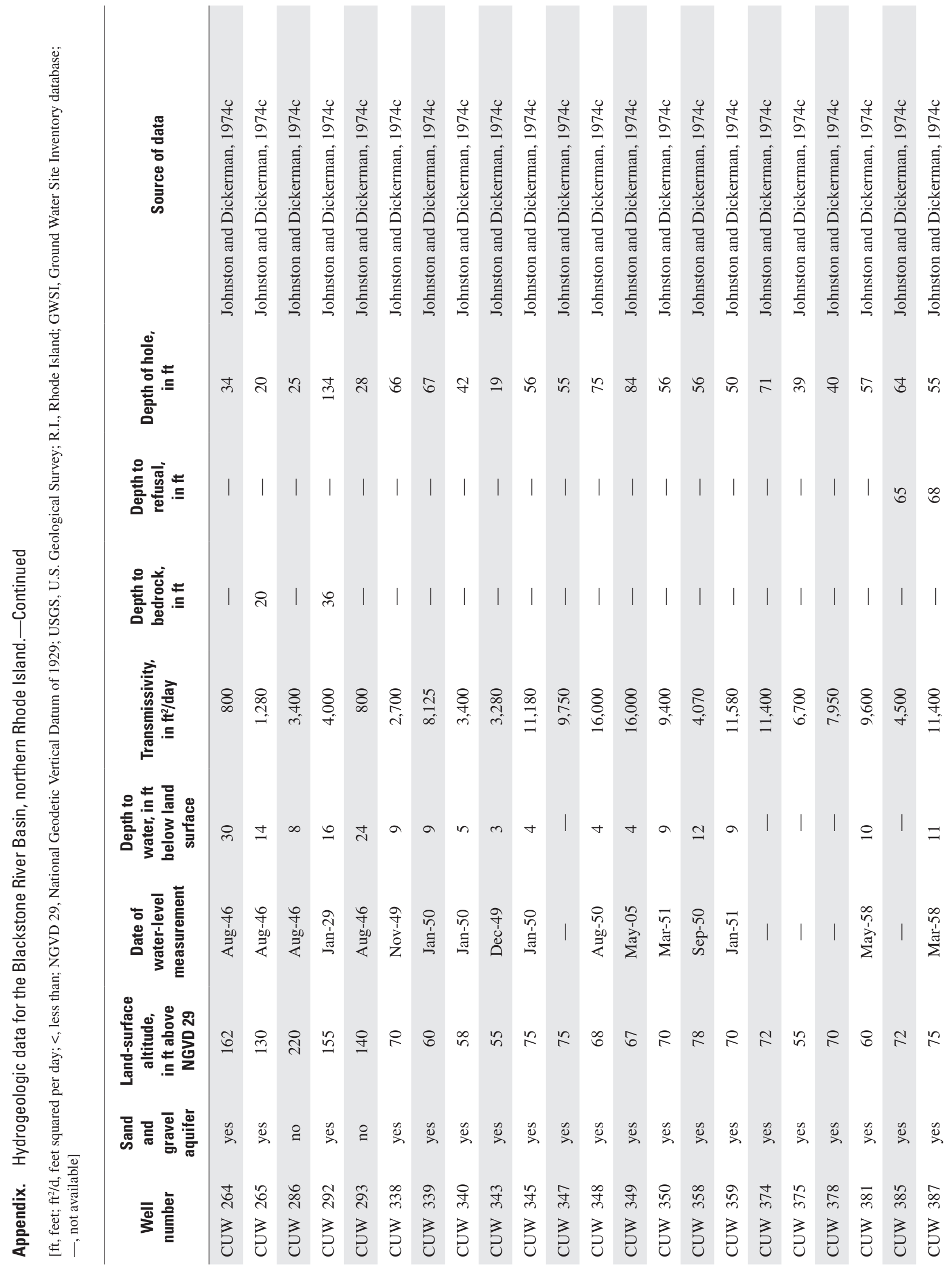




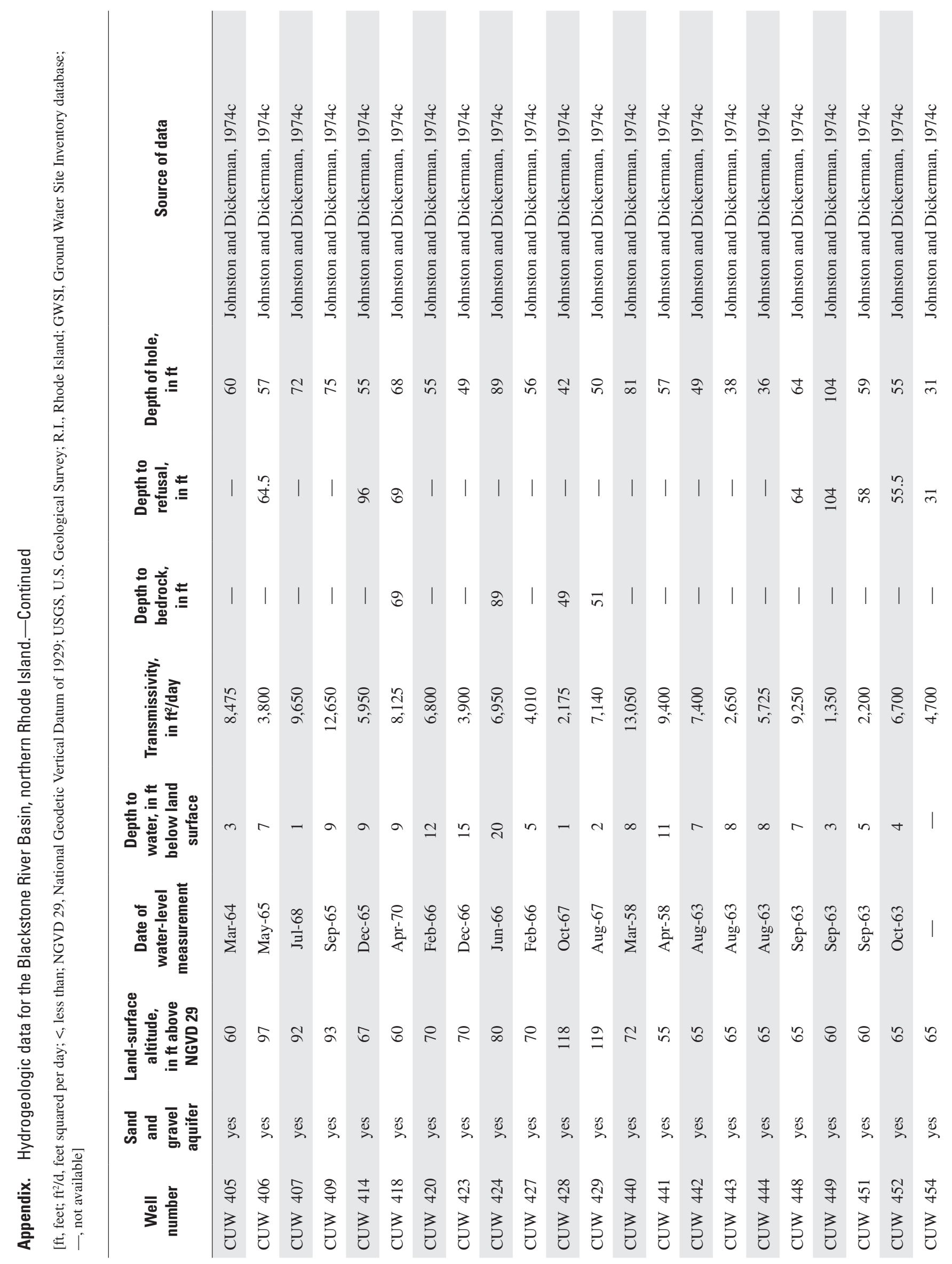




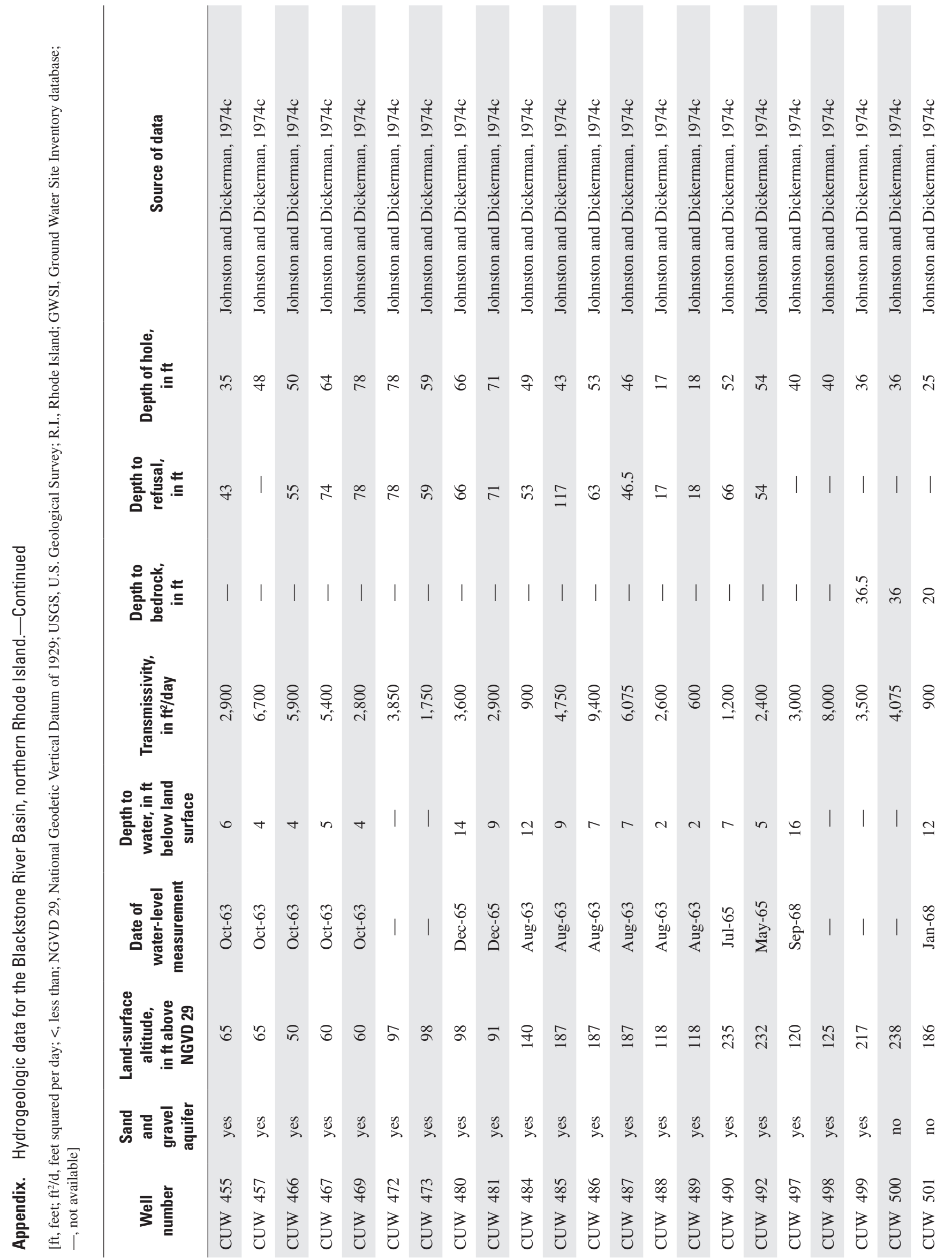




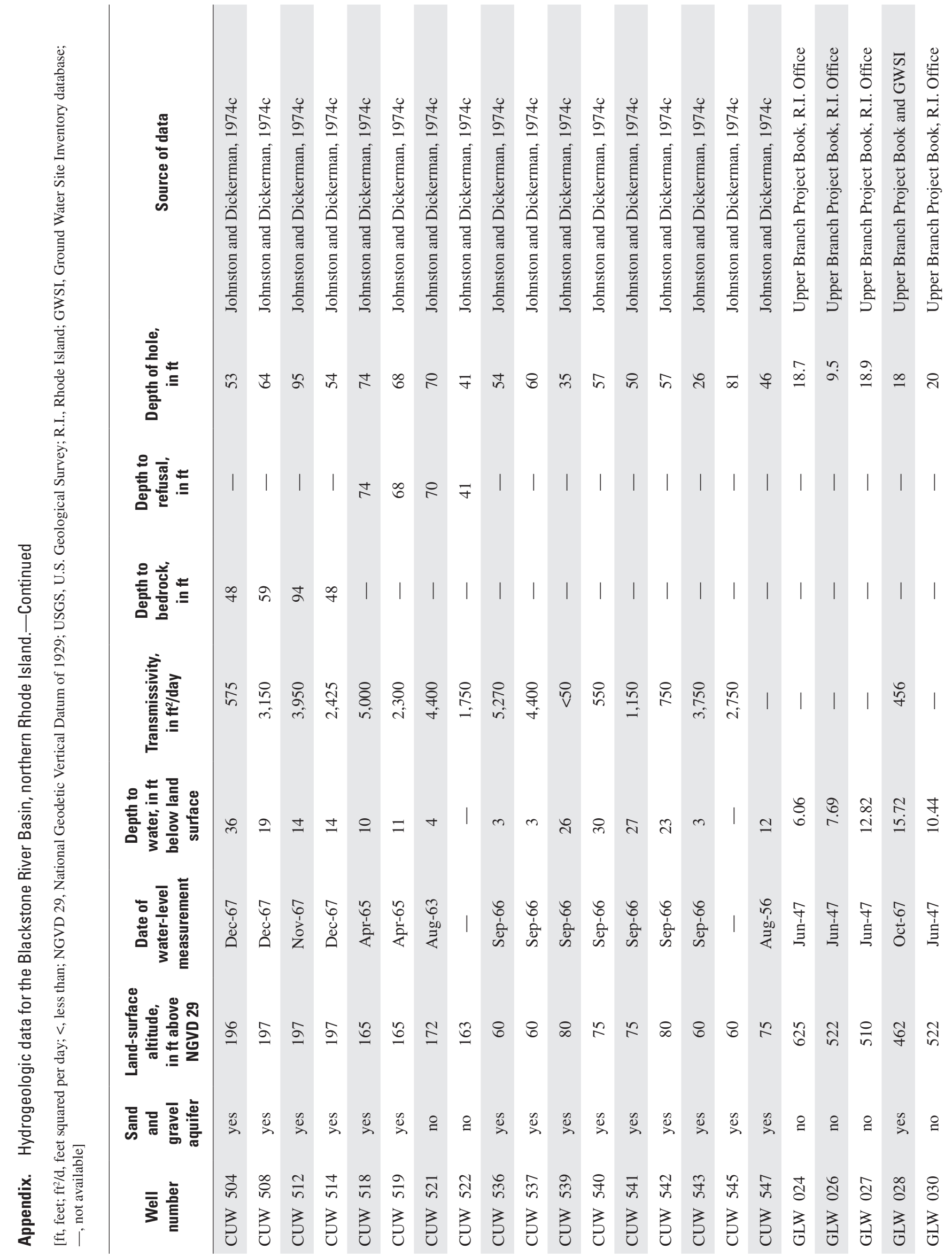




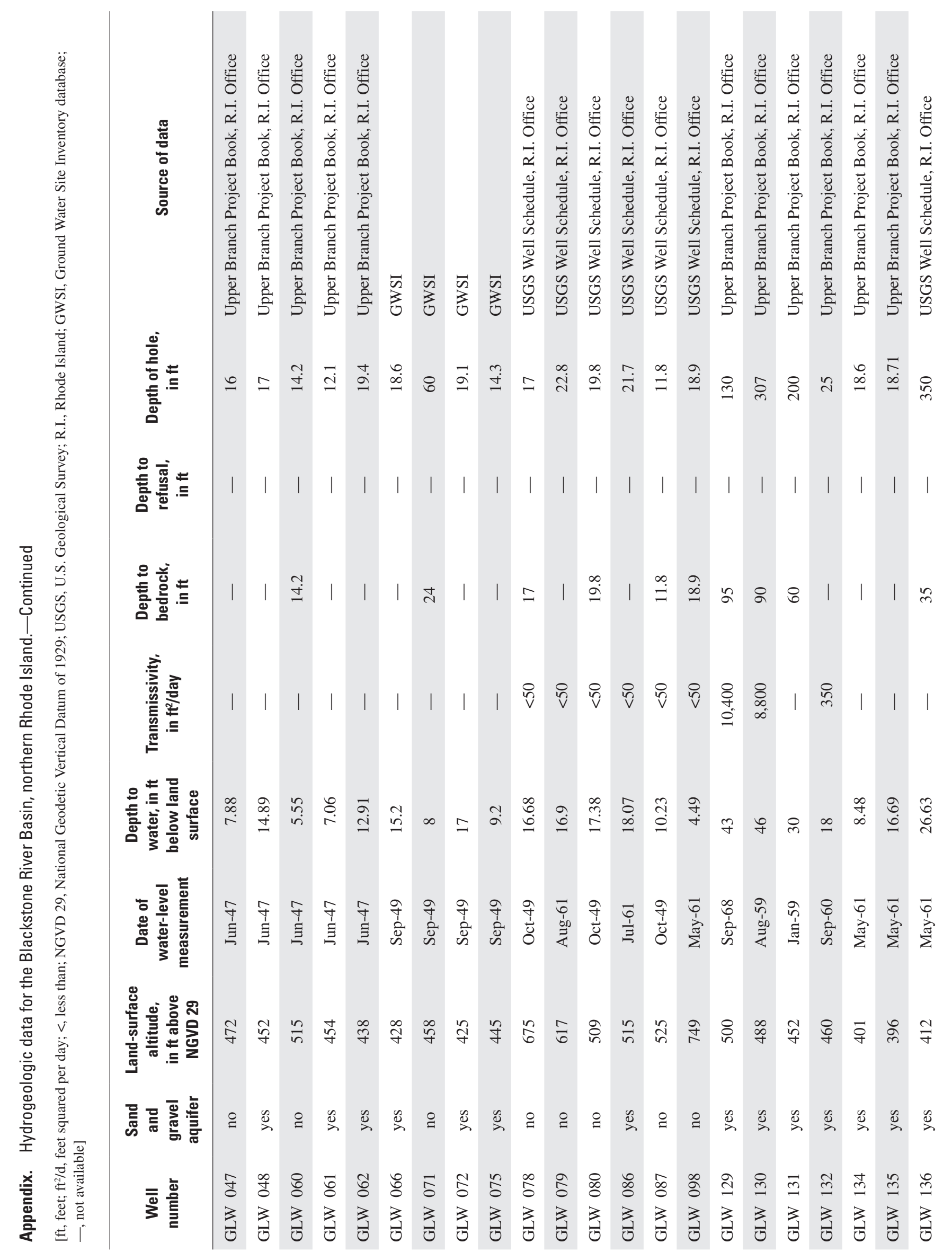




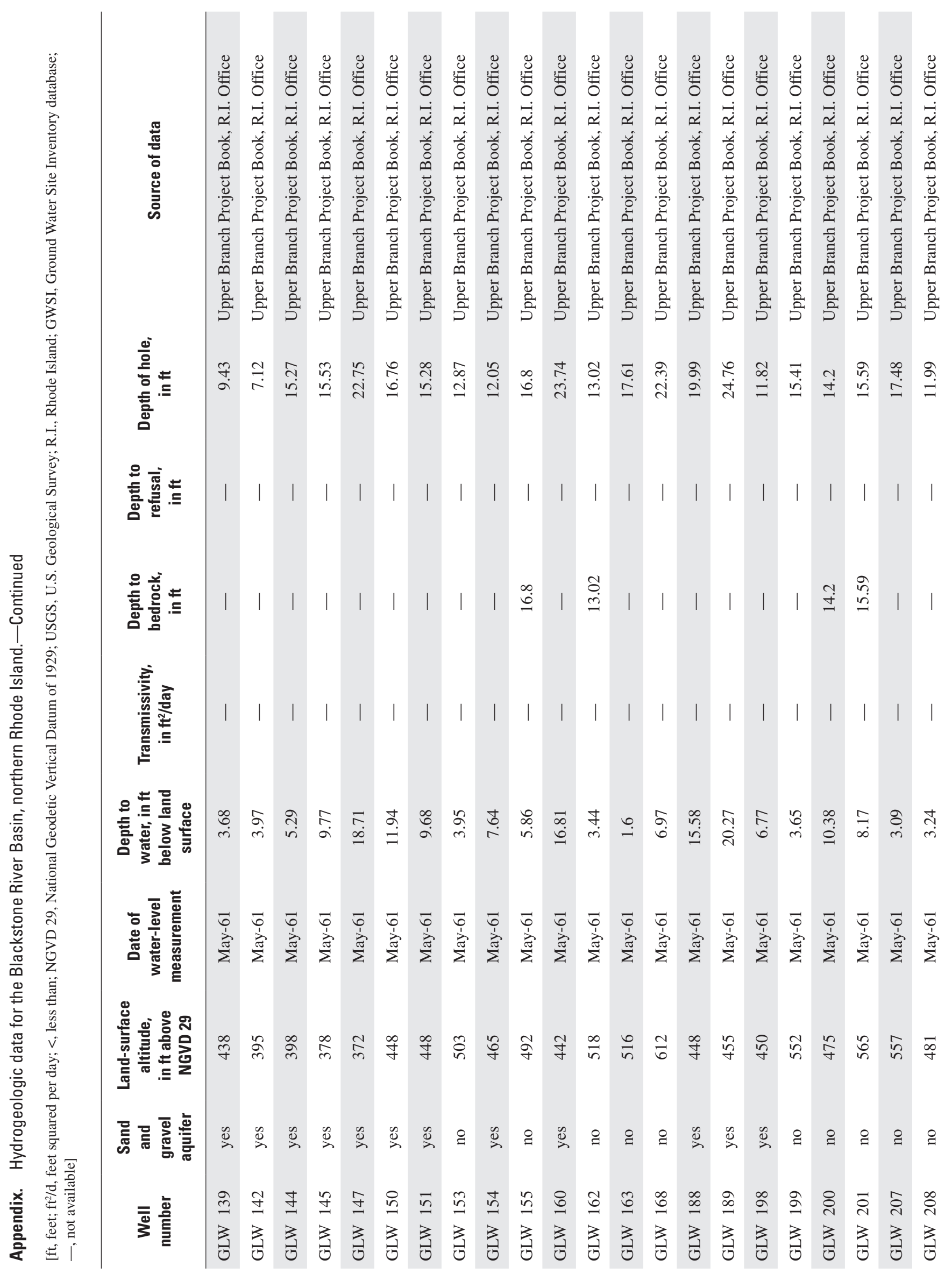




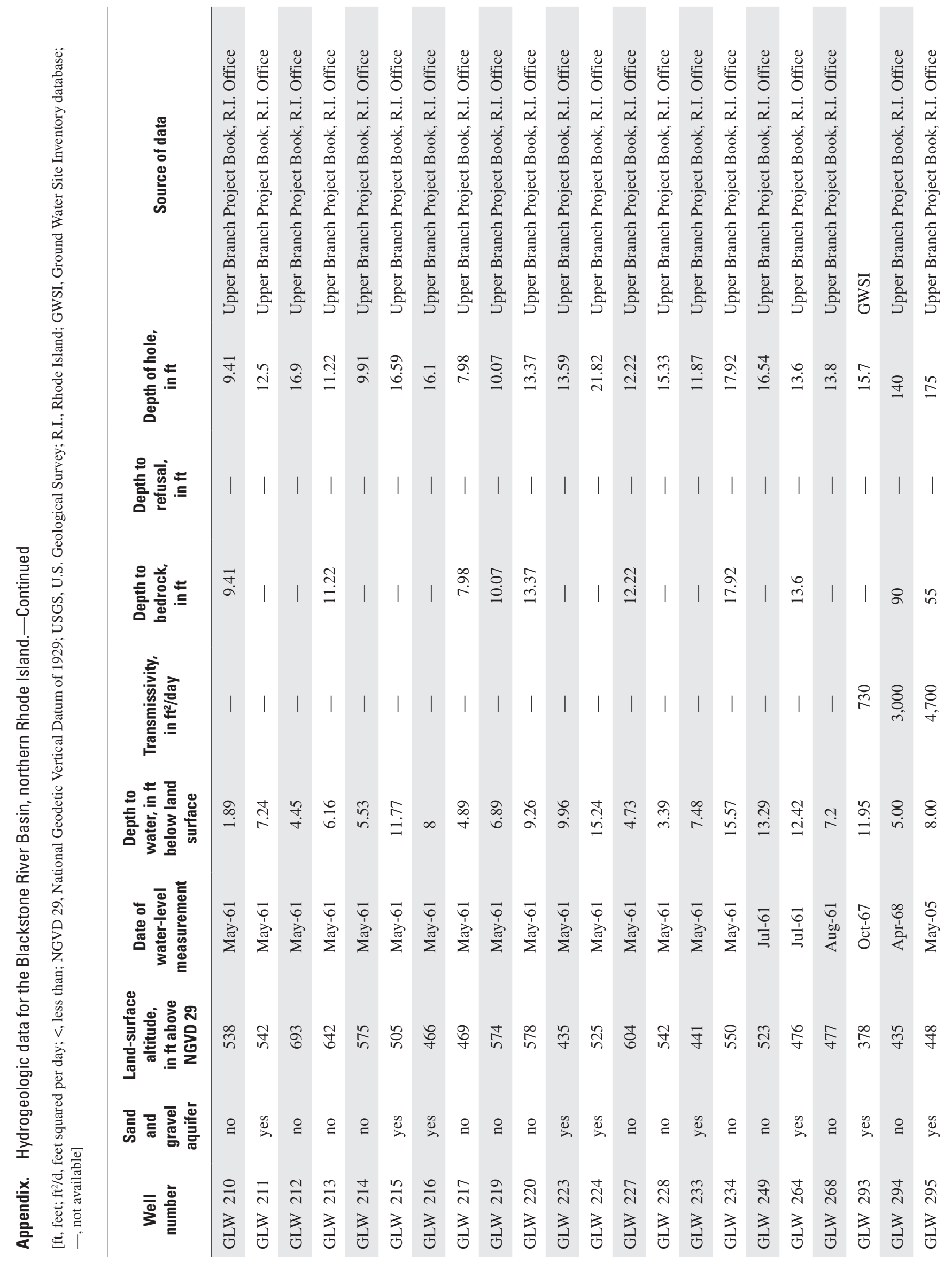




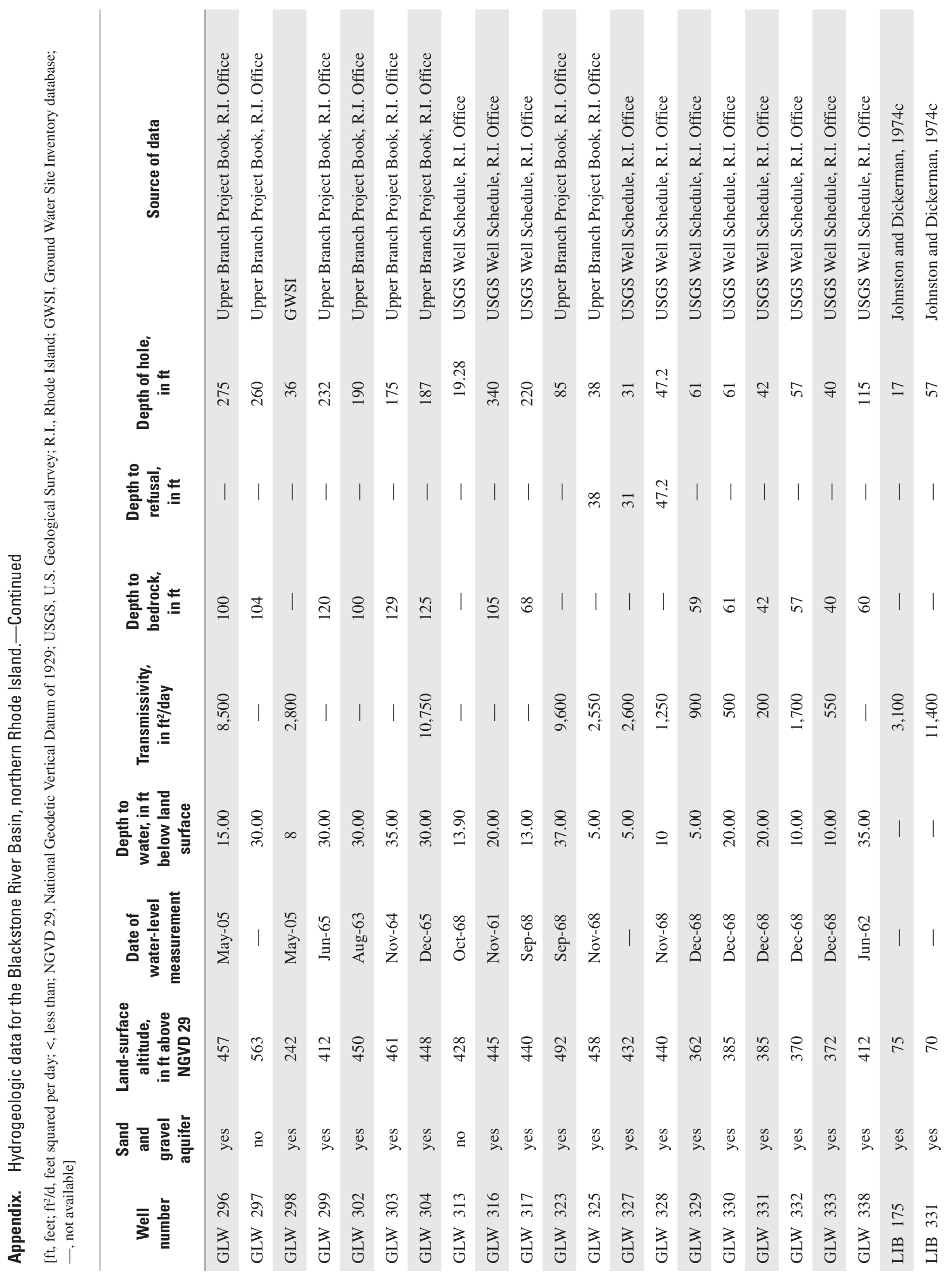




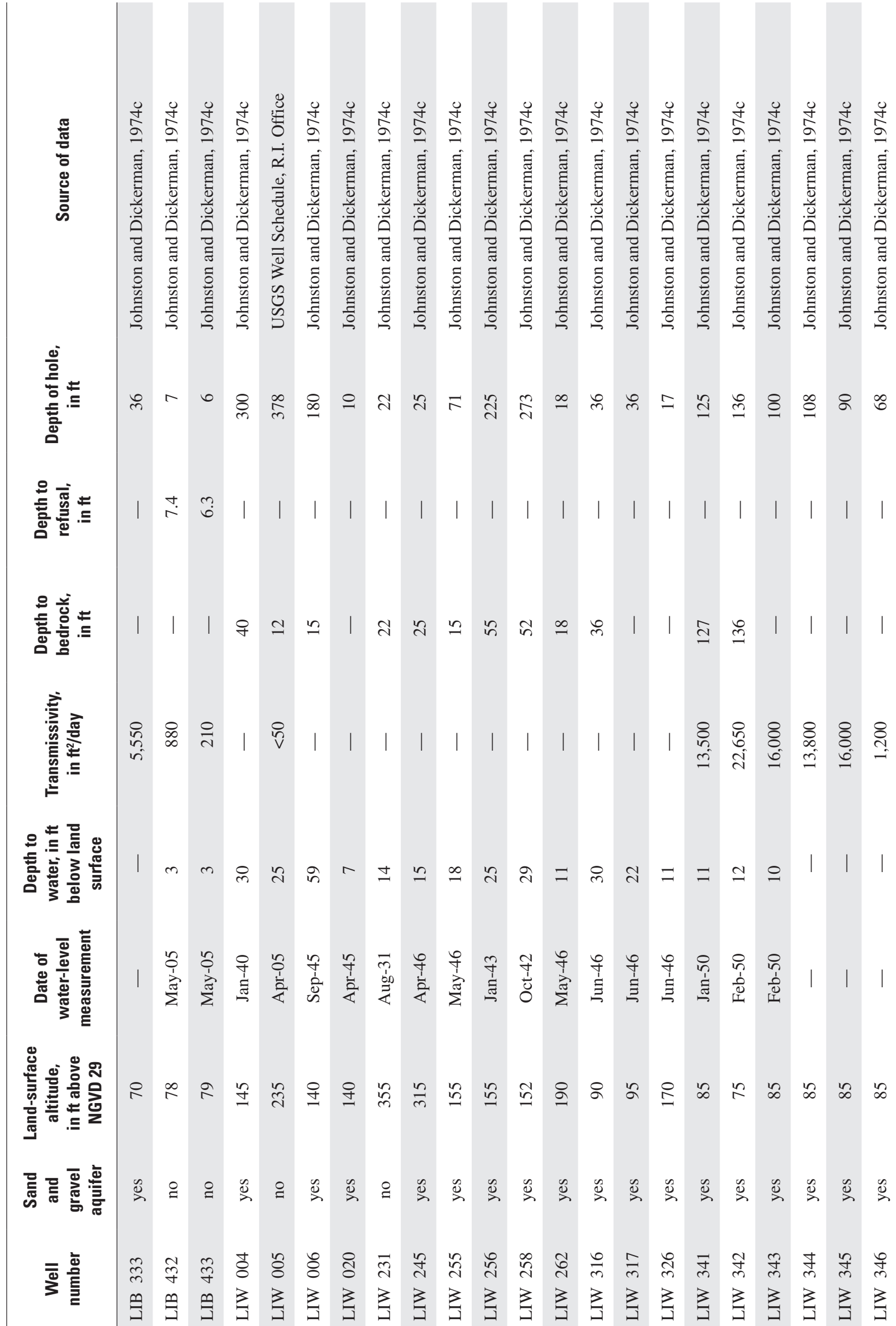




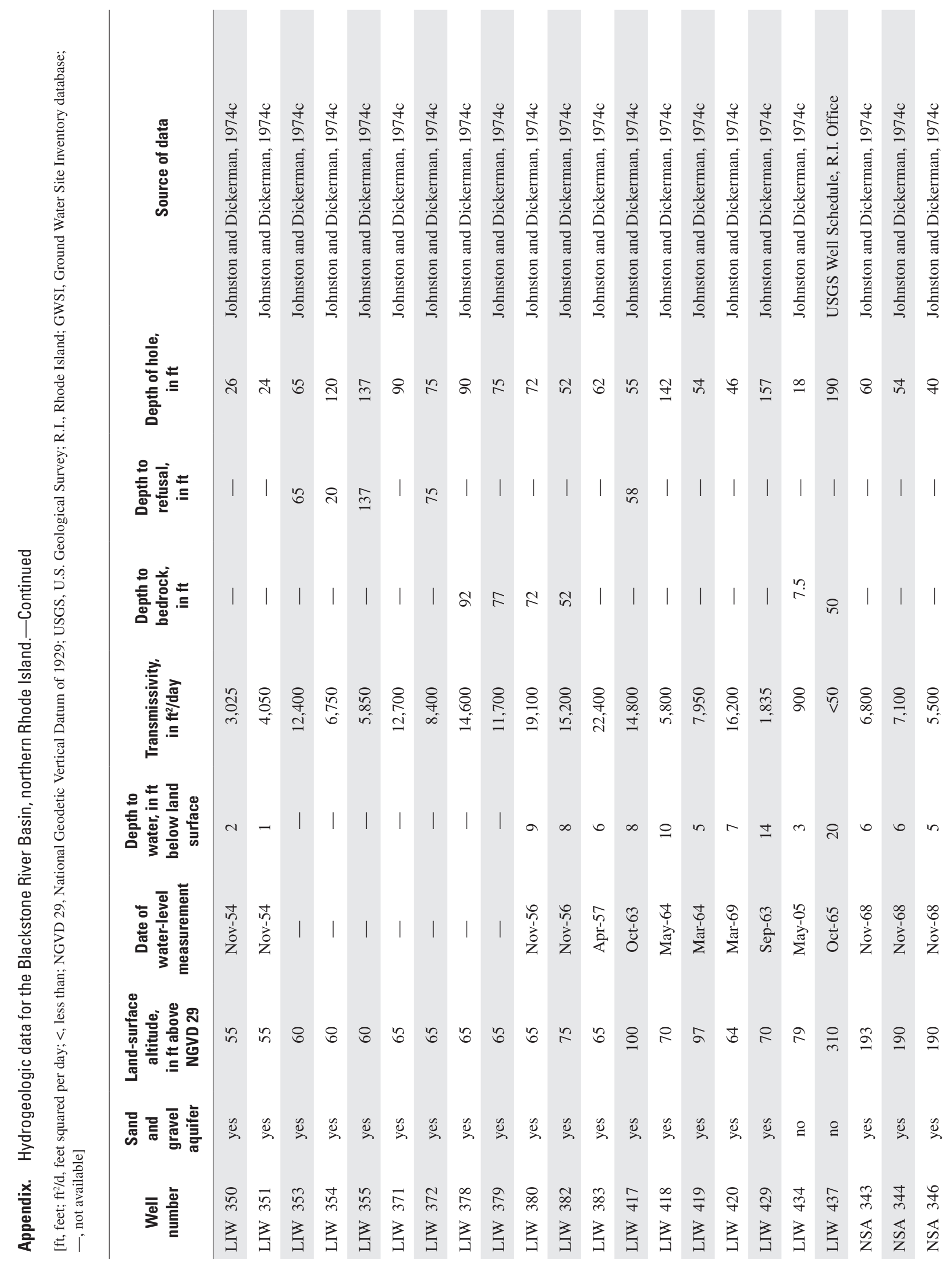




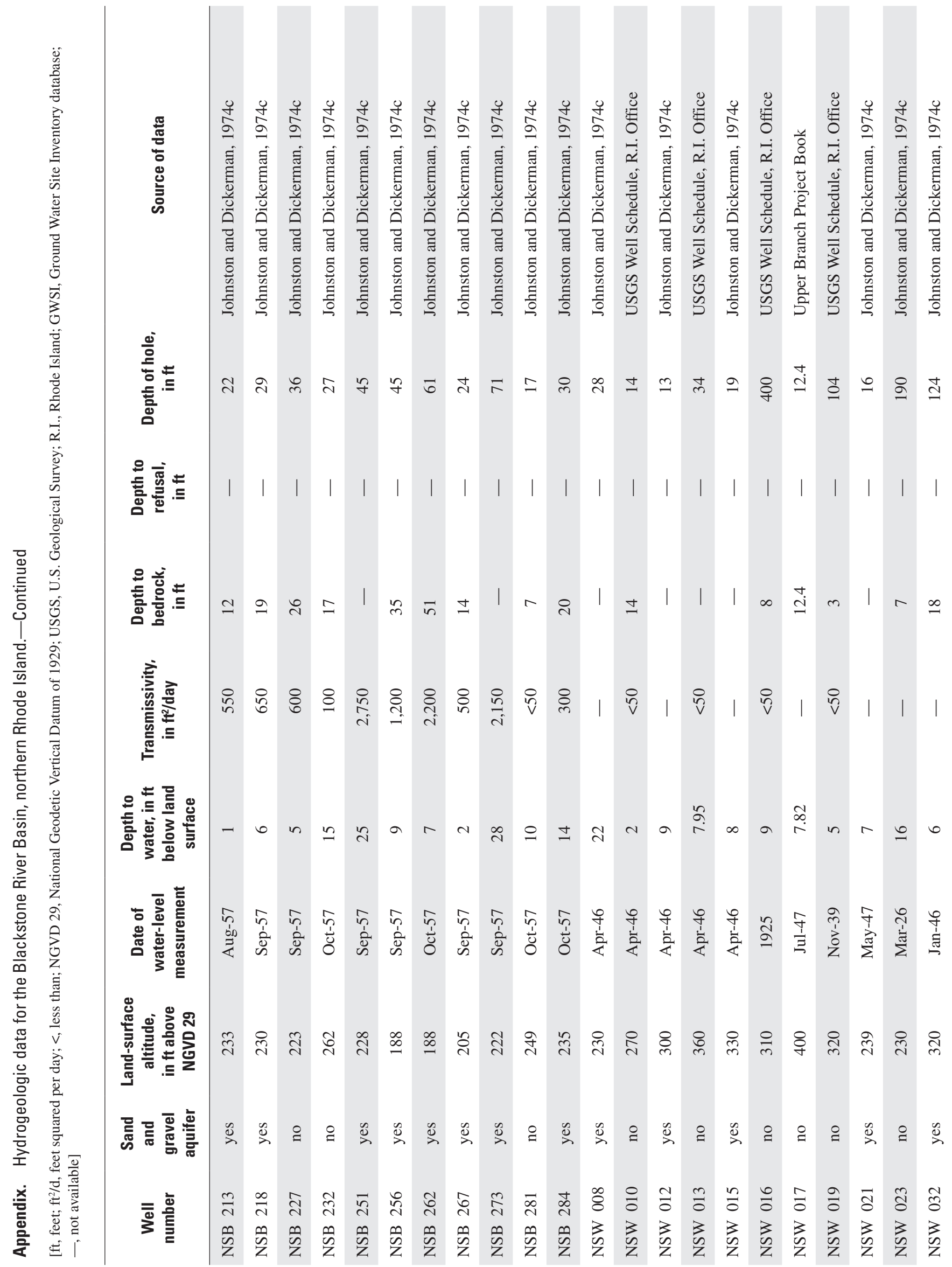




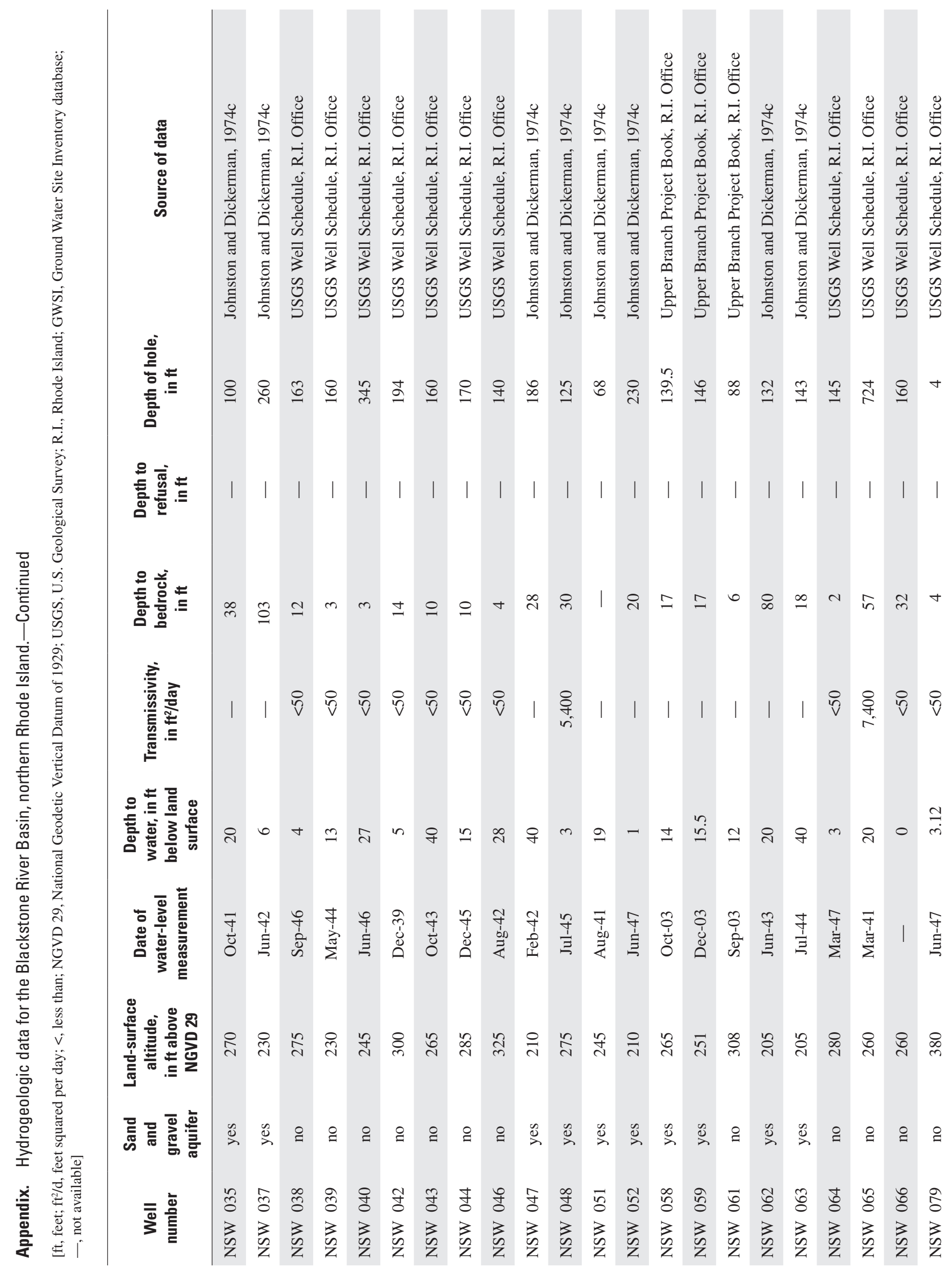




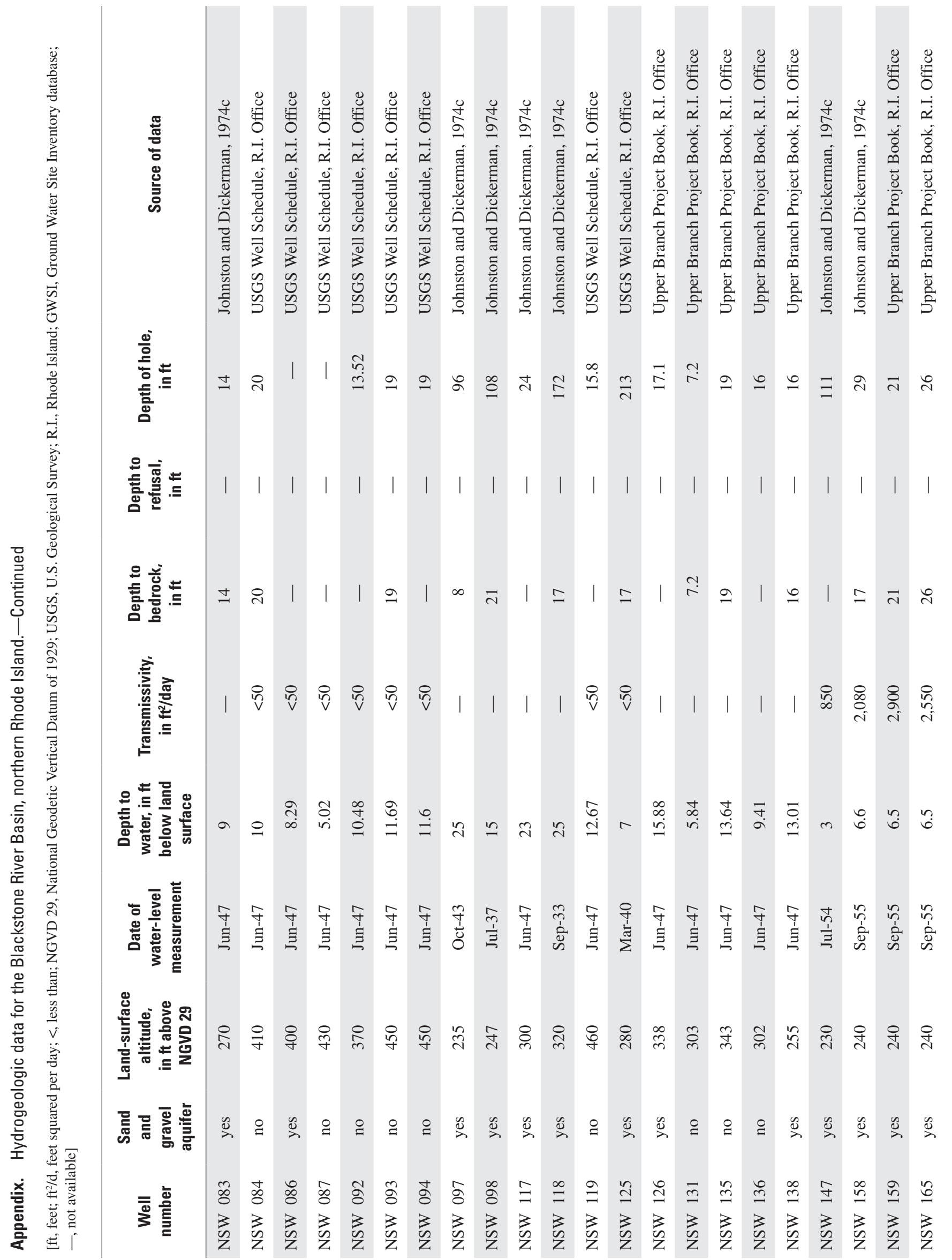




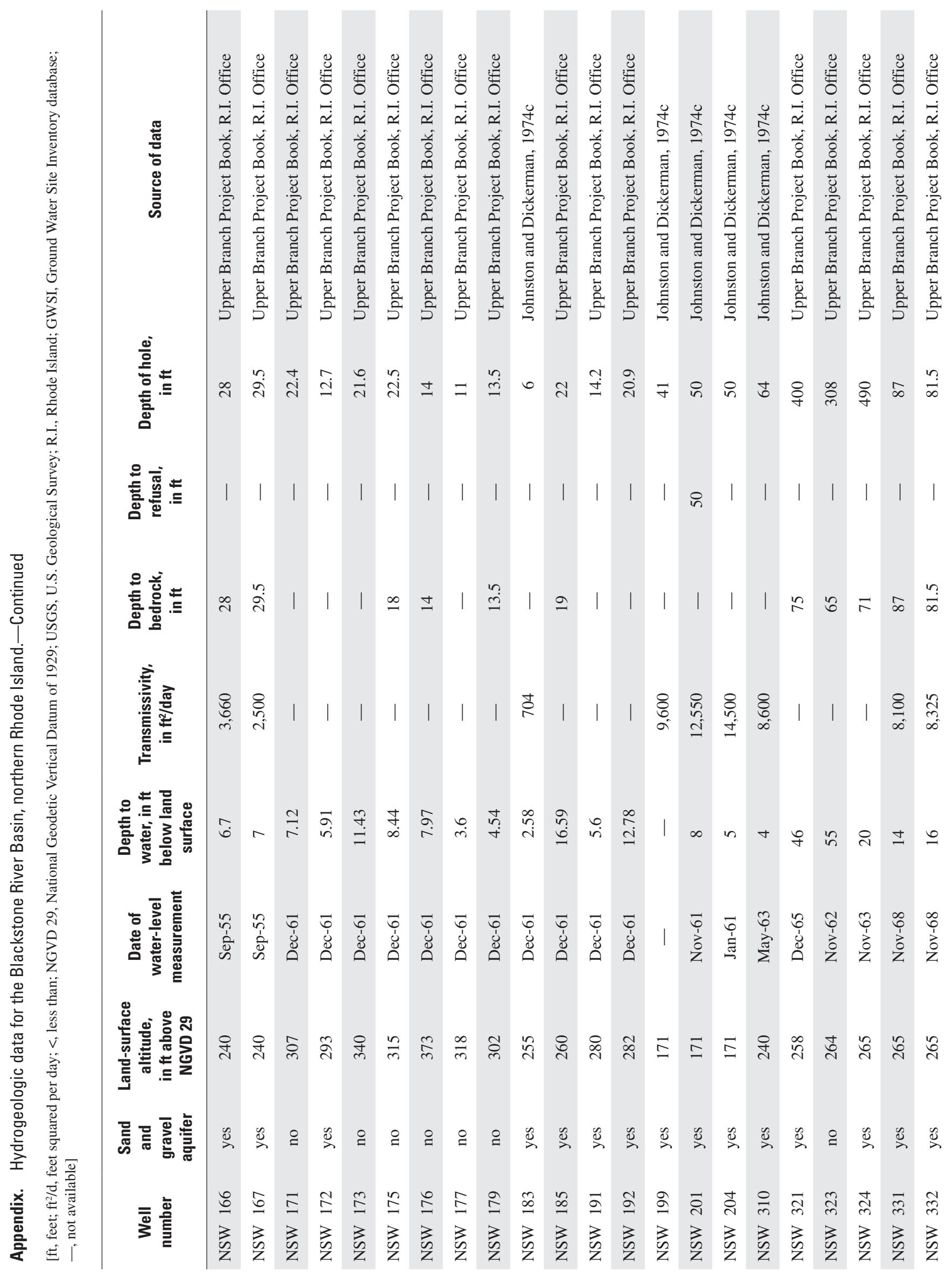




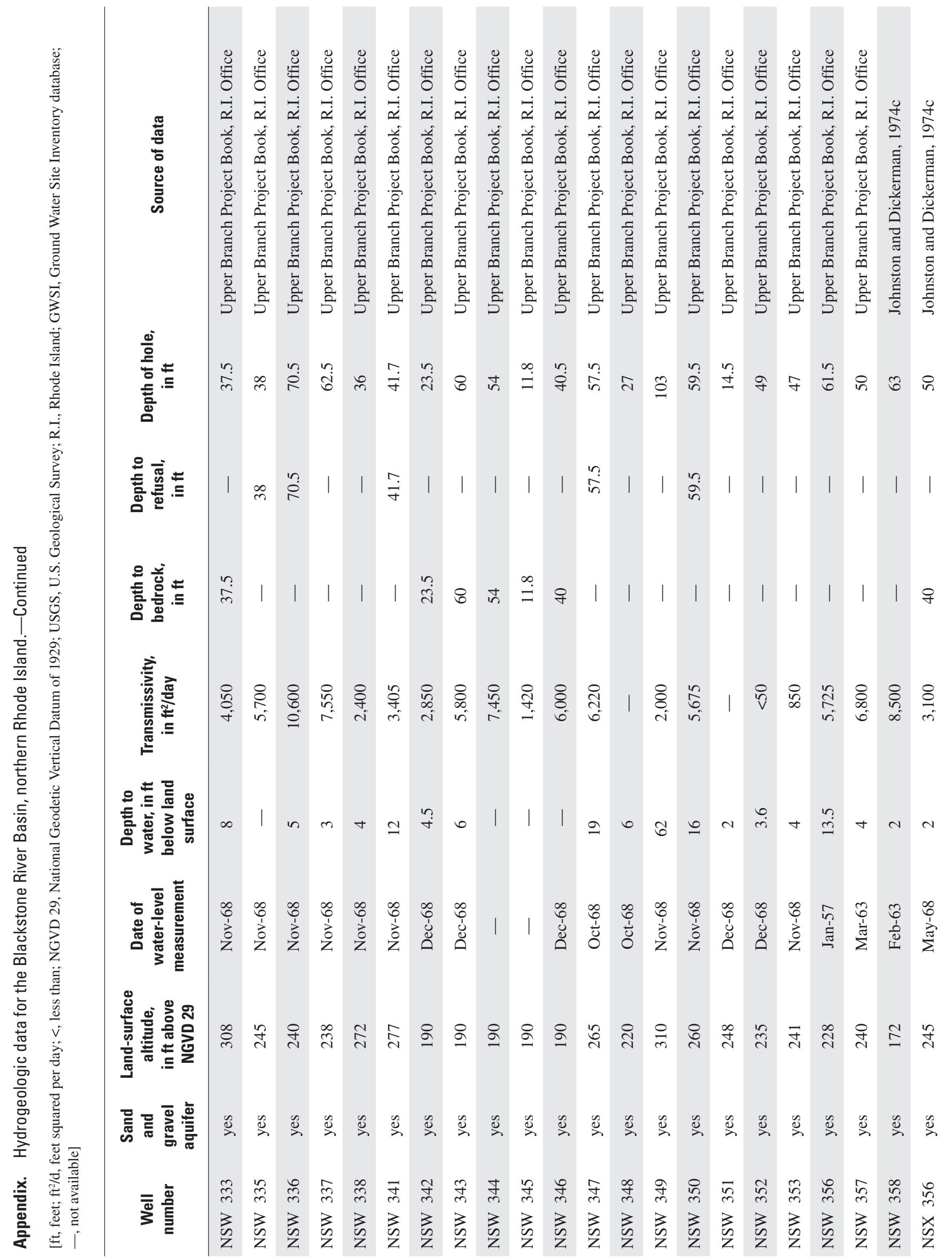




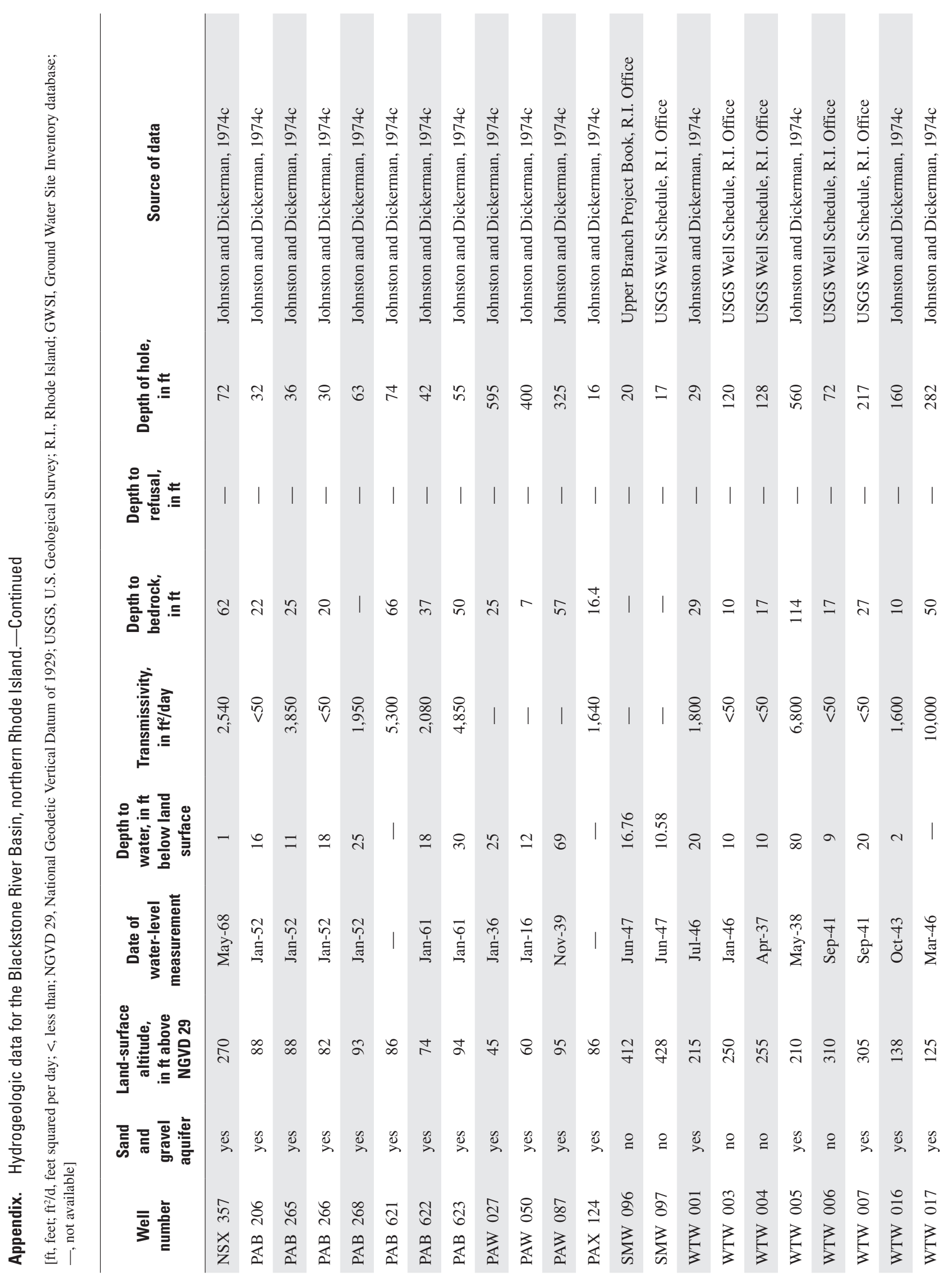




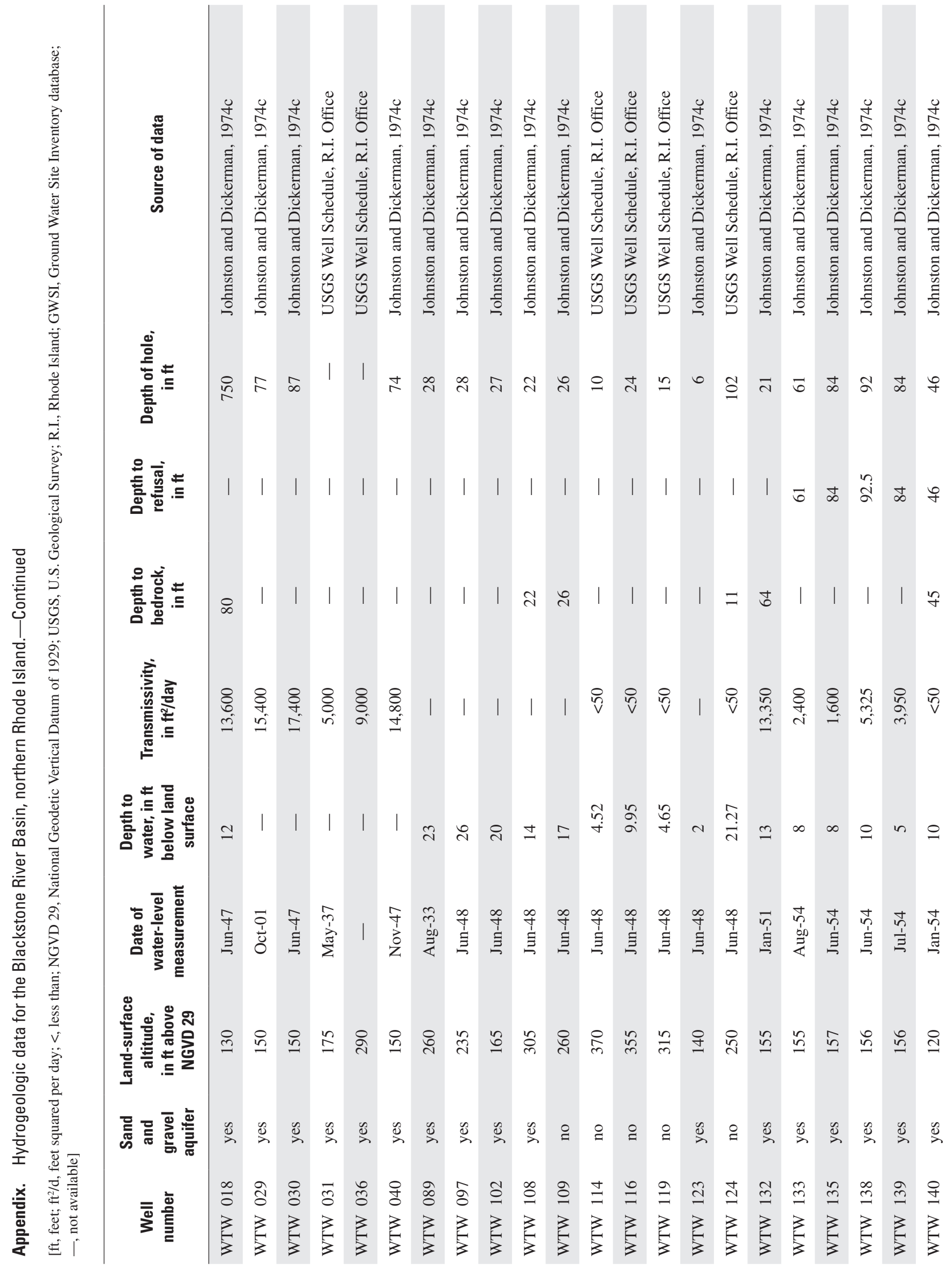




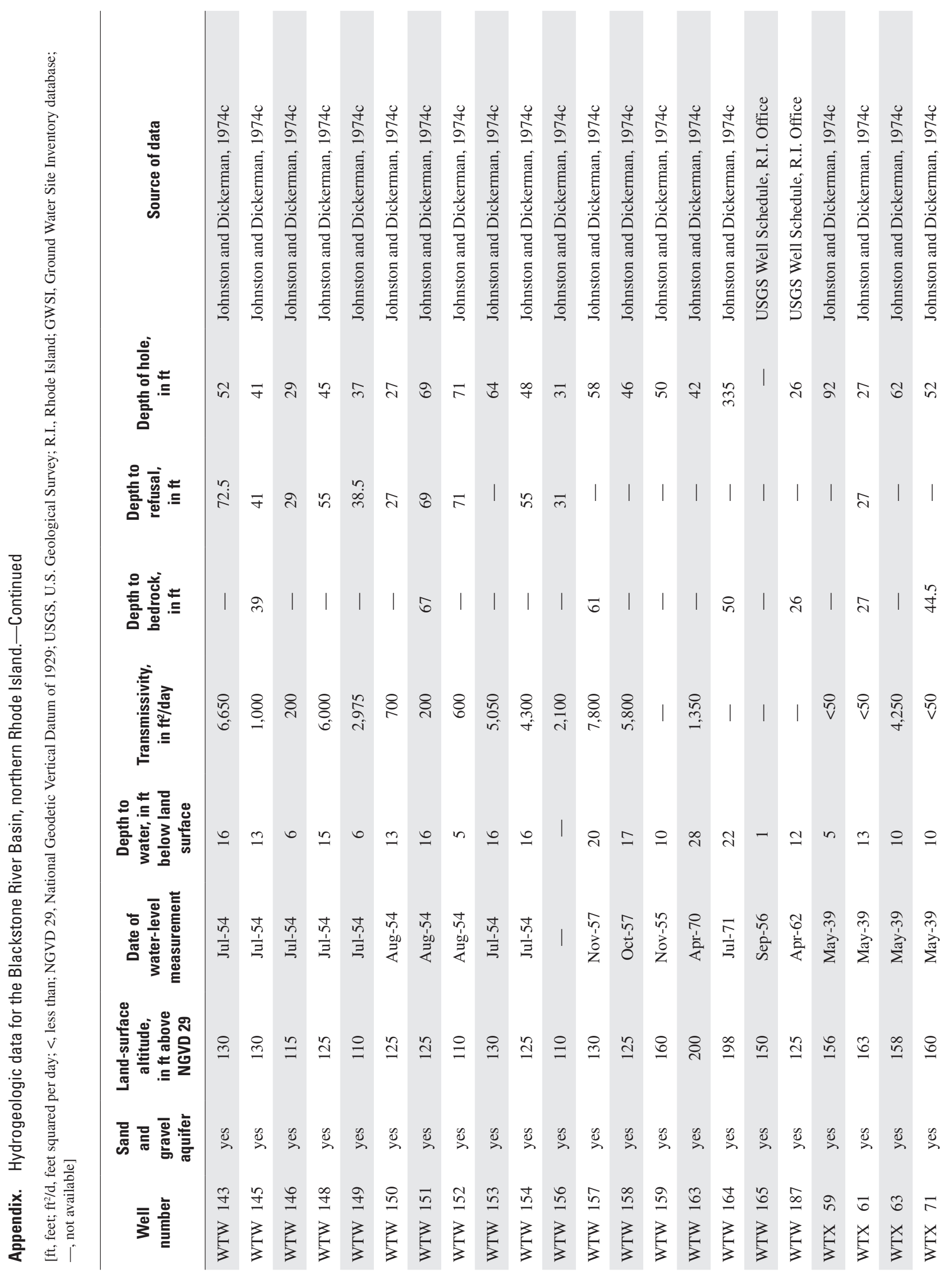




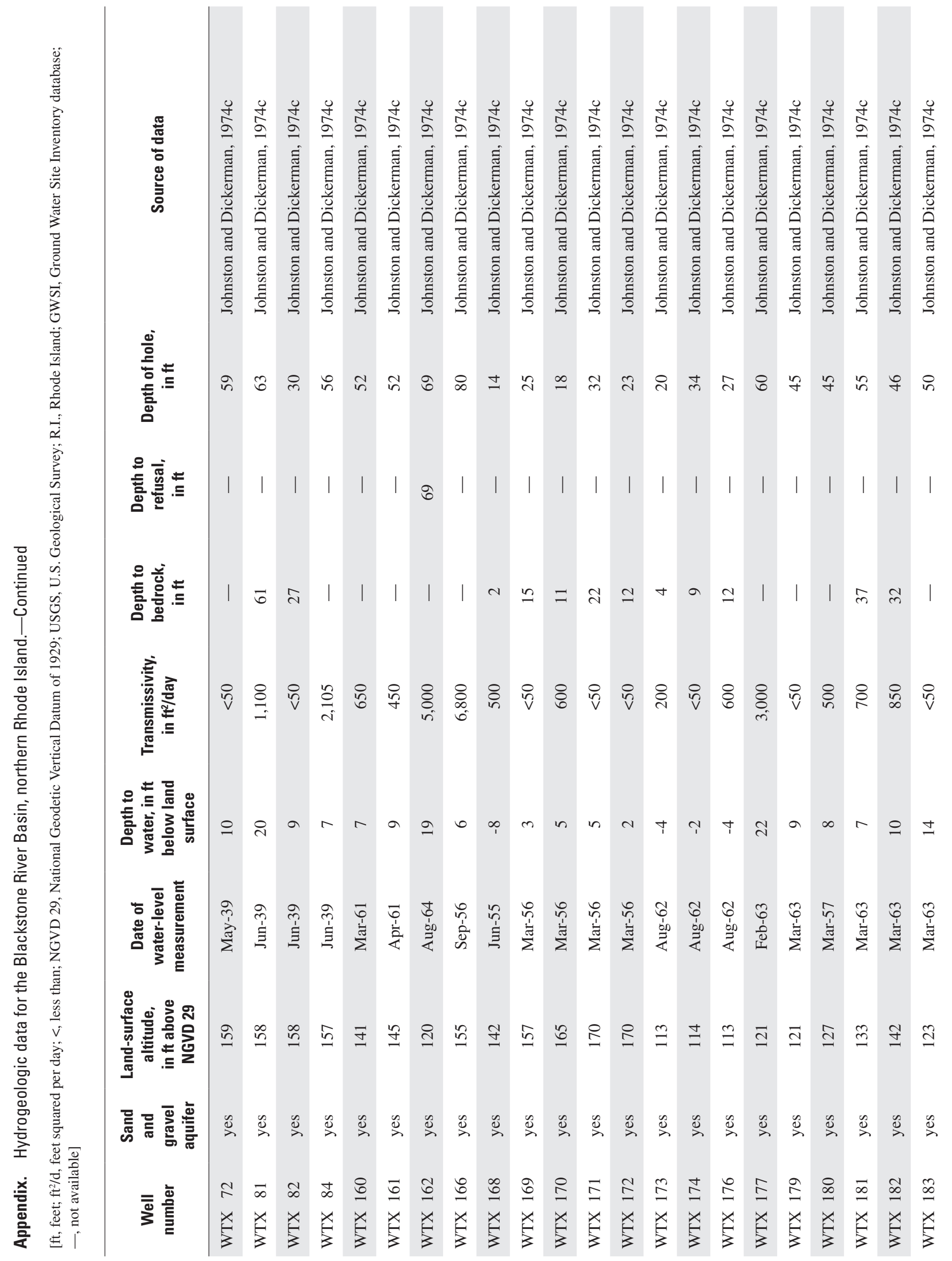




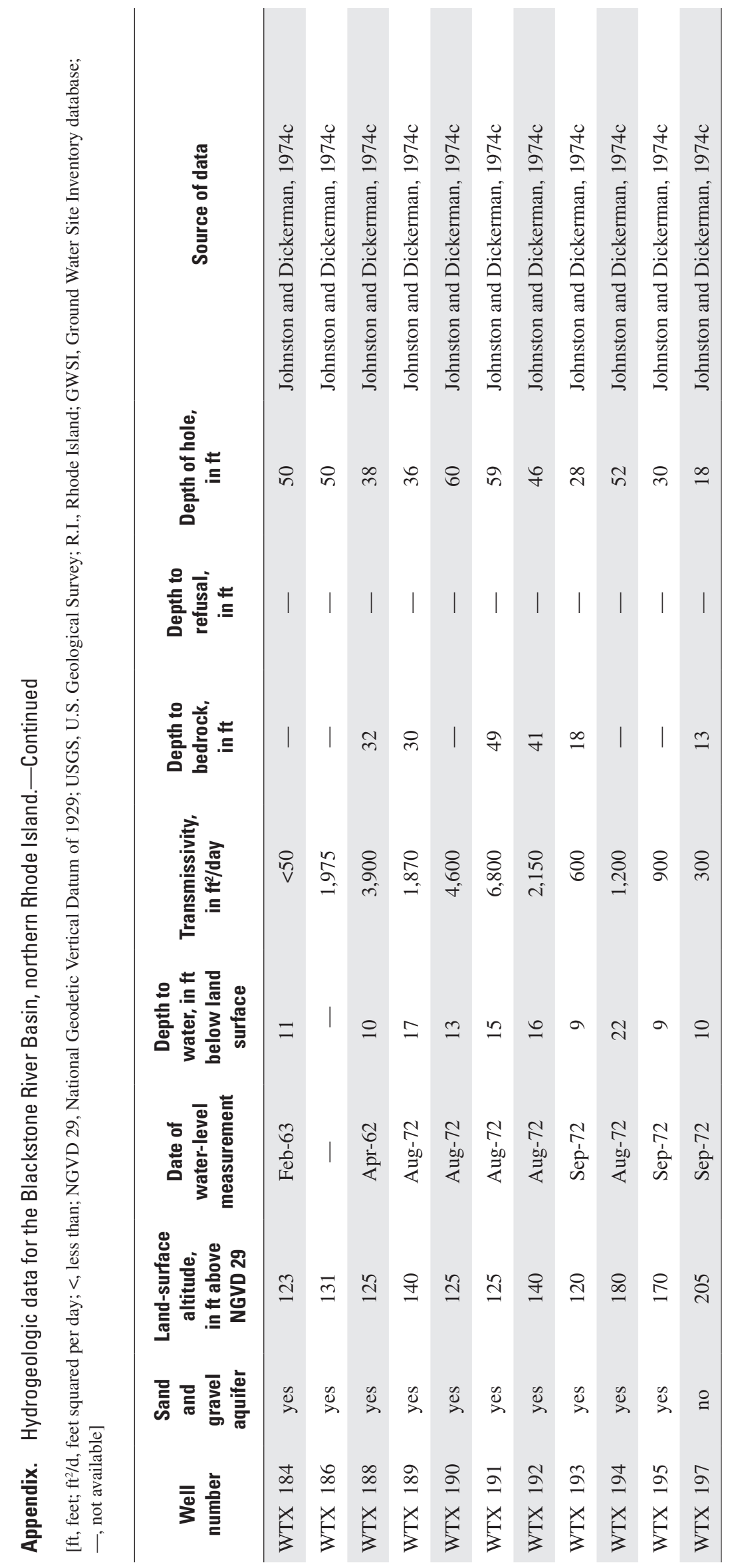



